\title{
Site U1320
}

\author{
Expedition 308 Scientists $^{2}$
}

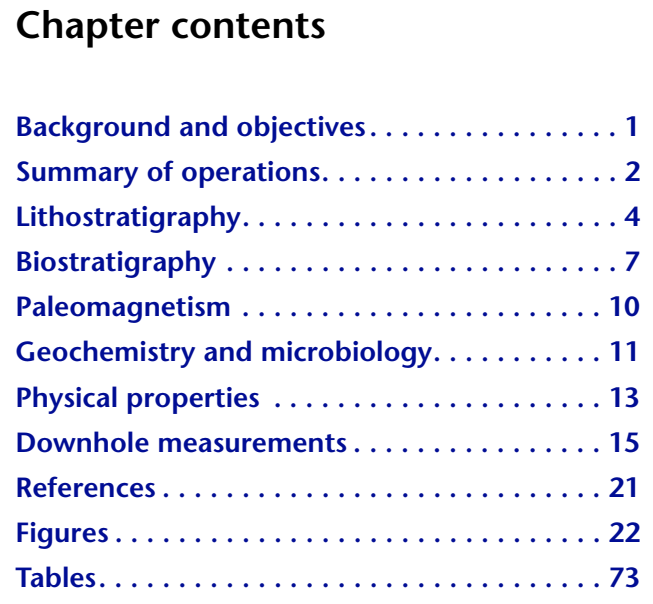

${ }^{1}$ Expedition 308 Scientists, 2006. Site U1320. In Flemings, P.B., Behrmann, J.H., John, C.M., and the Expedition 308 Scientists, Proc. IODP, 308: College Station TX (Integrated Ocean Drilling Program Management International, Inc.). doi:10.2204/iodp.proc.308.104.2006

'Expedition 308 Scientists' addresses.

\section{Background and objectives Geological setting of Brazos-Trinity Basin IV}

The geological framework of Brazos-Trinity Basin IV is described in "Background and objectives" in the "Site U1319" chapter, and the reader is referred to this chapter regarding necessary background information, along with an extensive compilation of precruise data in figures and tables (Figs. F1, F2, F3, F4, F5, F6, F7, in the "Site U1319" chapter; Table T1 in the "Site U1319" chapter).

\section{Overview of seismically mapped surfaces}

Site U1320 is located in $1470 \mathrm{~m}$ water depth near the center of Brazos-Trinity Basin IV (Fig. F4 in the "Site U1319" chapter). Twodimensional (2-D) seismic data show that the drilling location is a short distance away from the southern boundary of a bowlshaped basin (Fig. F5 in the "Site U1319" chapter). Here, the stratigraphic section was expected to be most expanded and most complete. Prior to drilling we mapped six major seismic reflectors (shown in Fig. F1) in Brazos-Trinity Basin IV: from shallowest to deepest, the seafloor reflector (SF) and seismic Reflectors R10, R20, R30, R40, R50, and R60 (see Table T1 in the "Site U1319" chapter). Below seismic Reflector R40, sediment packages are of approximately equal thickness along the seismic section, and we infer that these sediments were deposited before any local topography developed as a result of salt movement or other tectonic factors. Seismic Reflector R60 at $2310 \mathrm{~ms}$ two-way traveltime (TWT) (284.3 meters below seafloor [mbsf]) (Table T1 in the "Site U1319" chapter) separates a well-stratified package above from an area of short and more chaotically oriented reflections below. Seismic Reflector R50 at 2254 ms TWT (229 mbsf) marks a prominent seismic signal at the center of this package. Seismic Reflector R40 at 2189 ms TWT (179 mbsf) defines the top of the constant-thickness beds. Above this reflector, seismic Reflectors R30 (2141 ms TWT; 138 mbsf), R20 (2070 ms TWT; 79.6 mbsf), and R10 (2008 ms TWT; 29.9 mbsf) cap three layered reflective packages in this central position of Brazos-Trinity Basin IV. With the exception of the lower package, which is seismically stratified throughout at least south-southwest, west-northwest, and eastsoutheast of Site U1320 (Figs. F5, F6 in the "Site U1319" chapter), the lower parts are acoustically transparent and the upper parts show a well-defined, even, stratification. 


\section{Local summary of borehole expectations}

Beneath a Holocene hemipelagic mud drape a few meters thick, the expected uppermost Pleistoceneage lithologies were muddy and sandy deepwater fan turbidites to a depth of $\sim 180$ mbsf, roughly equivalent to the position of seismic Reflector R40 (Fig. F1). The depositional environment of these sediments was anticipated to be that of a deepwater fan, according to the interpretations of Badalini et al. (2000) or Beaubouef and Friedmann (2000) (see Fig. F3 in the "Site U1319" chapter). The fan deposits are underlain by interbedded hemipelagic and turbidite muds. Downsection from seismic Reflector R40 to Reflector R60, the seismic signature extending from the southern flank of the basin was taken to represent the interbedded hemipelagic and turbidite muds sedimented before development of the fan. Seismic Reflector R60 was the final target for drilling at Site U1320. Beneath this depth, rocks of the earlier basin fill are probably slumped, producing a pattern of short, chaotically oriented reflections in seismic sections. Viewed on the scale of the whole Brazos-Trinity Basin IV, the packages bounded by seismic Reflectors R40 and R60 thicken somewhat to the north, perhaps reflecting proximity to the sediment source. Badalini et al. (2000) refer to these strata as hemipelagic deposits. Winker and Booth (2000) refer to the material between seismic Reflectors R40 and R60 as hemipelagic deposits and the other material as "chaotic."

\section{Drilling objectives}

The specific drilling objectives at Site U1320 were the following:

- Establish a complete section for the thick Holocene-latest Pleistocene late basin fill at the center of Brazos-Trinity Basin IV to determine the change in rock and fluid properties in this normally pressured location.

- Determine the age of the stratigraphic section and thus contribute to the derivation of an integrated age model for Brazos-Trinity Basin IV.

- Determine the lithology and facies evolution of the center of this basin, to allow lateral correlation with the drilled and/or logged sections at Sites U1319 and U1321.

- Sample the subsurface biosphere in this reference location.

- Conduct an extensive wireline logging program on the cored hole and a logging-while-drilling (LWD)/measurement-while-drilling (MWD) program on a dedicated LWD/MWD hole.
To achieve these objectives, Hole U1320A was continuously cored to terminal depth (TD) at $299.6 \mathrm{mbsf}$ and then wireline logged with the triple combination (triple combo) and Formation MicroScanner (FMS)-sonic tool strings and vertical seismic profiling using the single-axis Well Seismic Tool (WST). Special tool deployments in Hole U1320A during the coring program included two deployments of the temperature/dual pressure (T2P) probe at 126.2 and 213.0 mbsf and two deployments of the Davis-Villinger Temperature-Pressure Probe (DVTPP) at 203.4 and 289.9 mbsf. A dedicated second hole (Hole U1320B) was then drilled to conduct LWD/MWD operations to a TD of $320 \mathrm{mbsf}$. This was done to generate a complete set of logging parameters for correlation with core and wireline logging data from Hole U1320A.

\section{Summary of operations}

\section{Hole U1320A}

A summary of operations in Hole U1320A can be found in Table T1. The JOIDES Resolution arrived at Site U1320 on the evening of 7 June 2005, and a beacon was dropped at $0040 \mathrm{~h}$ on 8 June. The vibrationisolated television (VIT) camera was launched and the drill string lowered to 1469.6 meters below rig floor (mbrf), where the seafloor was observed. When what seemed to be a man-made object (possibly a plastic bag) was observed under the bit, the vessel was offset $5 \mathrm{~m}$ north. After the driller tagged the seafloor at $1479.4 \mathrm{mbrf}$, he raised the bit to $1475.4 \mathrm{mbrf}$ in preparation for spudding. Hole U1320A was spudded at $0420 \mathrm{~h}$ on 8 June. Recovery in the first core established the seafloor depth at $1480.4 \mathrm{mbrf}$, or $4.0 \mathrm{~m}$ shallower than the corrected precision depth recorder depth. Advanced piston corer (APC) coring advanced to $69.4 \mathrm{mbsf}$, where a thick sandy layer prevented further penetration with the APC. Because sediments at the top of the hole were predominately sandy, it was considered unsuitable for deployment of the T2P probe. Coring continued with the extended core barrel (XCB) to 126.3 mbsf (Core 15X), where a clay-rich interval was identified. The T2P probe was deployed for the third time during the expedition, this time with a thicker tip. The probe landed in the bottom of the hole for $45 \mathrm{~min}$ while a minimum circulation of $10 \mathrm{spm}$ (60 gpm) was maintained. On this occasion, the probe was recovered with a slightly bent probe tip. Temperature and pressure measurements were successfully recorded.

XCB coring resumed and advanced to 203.4 mbsf (Core 23X), where a dedicated coring line trip was utilized to obtain a DVTPP temperature measure- 
ment at the bottom of the hole. After one more XCB core was obtained to deepen the hole to $213.0 \mathrm{mbsf}$, coring was again stopped for another T2P run. The T2P probe was deployed for the fourth time at 213.0 mbsf. For this run, the bottom-hole assembly (BHA) was placed only $1 \mathrm{~m}$ above the bottom of the hole, allowing better centering of the probe and possibly responsible for the tip of the T2P retaining its shape on this run. XCB coring resumed and the hole was deepened from 213.0 to 289.9 mbsf (Core 32X), where another DVTPP bottom hole temperature measurement was attempted. Coring concluded when one final XCB core deepened the hole to 299.6 mbsf. Because the scientific objectives for this hole were realized, it was not necessary to continue to the original projected depth of 340 mbsf. The APC cored $69.4 \mathrm{~m}$ with an average recovery of $101.9 \%$. The cores were oriented starting with Core $4 \mathrm{H}$, and fluorescent microspheres were deployed in all APC core catchers. Nonmagnetic hardware was used for all piston cores. The XCB penetrated $230.2 \mathrm{~m}$ and recovered $180.2 \mathrm{~m}$ for an average recovery of $78.3 \%$. The total cored interval was $299.6 \mathrm{~m}$ with an average recovery of $83.7 \%$. While coring was concluding in Hole U1320A, an oilfield supply boat (Emily $G$ ) arrived at $0415 \mathrm{~h}$ on 10 June and quickly discharged to our vessel the MWD drilling hardware and one Anadrill engineer (David Domalakes) via eight crane lifts. The vessel departed at $0520 \mathrm{~h}$. Consonant with the protocol for arriving passengers, David Domalakes was provided with a health, safety, and environmental orientation by the Chief Mate. After these formalities were concluded, David joined his colleague, Kelvin Hoong (already aboard), as they began to unpack, assemble, and test the MWD hardware.

\section{Downhole logging}

In preparation for logging, the hole was flushed with a 50 bbl high-viscosity mud sweep followed by a wiper trip to $56.7 \mathrm{mbsf}$ and back to bottom. After circulation of another $50 \mathrm{bbl}$ sepiolite mud sweep, the hole was displaced with $96 \mathrm{bbl}$ of logging mud. The bit was then pulled back to the logging depth of 62.5 mbsf.

Downhole logging of Hole U1320A was undertaken with three tool strings: the triple combo, FMS-sonic, and WST. All tools reached the bottom of the hole and the logs obtained were good. A contact between the turbidite fan sediments and the stiffer hemipelagic mud unit was clearly identified at 174 mbsf. WST measurements were undertaken, but in accordance with the Integrated Ocean Drilling Program (IODP) Marine Mammal Safety protocol, these operations were interrupted when a bottle-nosed dolphin was spotted $5 \mathrm{~m}$ from the vessel. After no more ma- rine mammal sightings were reported for $45 \mathrm{~min}$, the generator-injector (GI) gun was soft-started in accordance with protocol and 12 WST stations were completed without further incident. Once the logging equipment was rigged down, the VIT camera was deployed and the hole was observed as the drill string was pulled clear of the seafloor at $1930 \mathrm{~h}$ on 10 June 2005. As expected, logging mud quickly obstructed the view and the camera was promptly recovered. After the bit cleared the rotary table at $2245 \mathrm{~h}$, attention was directed to make up the MWD drilling assembly. Before that occurred, the drill crew performed the routine slipping and cutting of $115 \mathrm{ft}$ of drilling line.

\section{Hole U1320B}

A summary of operations in Hole U1320B can be found in Table T2. In accordance with the drilling plan, MWD augmented the coring and downhole logging data set at the Brazos-Trinity Basin IV sites. These sites served as a reference location for physical and chemical properties. MWD data provide information throughout the drilling depth on physical properties and are used to test spatial variations in rock properties associated with the flow-focusing model. MWD tools deployed in Hole U1320B include the GeoVision Resistivity (GVR) tool and Azimuthal Density Neutron (ADN) tool, and measurements included pressure (annular pressure while drilling [APWD]). The GVR provided azimuthal resistivity images of the borehole and gamma ray measurements, the ADN provided azimuthal boreholecompensated formation density, neutron porosity, and photoelectric factor (PEF) measurements, and APWD provided measurements of annulus pressure for identifying potential shallow flow and overpressure conditions. The MWD drilling array described above was made into a complete BHA by the addition of a $97 / 8$ inch Security M44NF mill tooth bit, a crossover sub to five controlled-length drill collars, a tapered drill collar, six joints of $5 \frac{1}{2}$ inch drill pipe, and a crossover sub. The total length of the BHA was $144.8 \mathrm{~m}$. The trip to the seafloor was interrupted at 288 mbrf to function test the assembly with pump and rotation. The VIT camera was also deployed with the drill string. Hole U1320B was spudded at $0915 \mathrm{~h}$ on 11 June 2005, when the driller observed (via the TV monitor) the bit contacting the seafloor at a depth of 1485.0 mbrf. After washing in the bit to 14.9 mbsf, the VIT camera was retrieved. The MWD drilling program was initiated and continued at an average rate of penetration (ROP) of $25.4 \mathrm{~m} / \mathrm{h}$ until the depth objective of $320.0 \mathrm{mbsf}$ was attainted at $0325 \mathrm{~h}$ on 12 June. The bit was then pulled out of the hole and cleared the seafloor at $0520 \mathrm{~h}$ on 12 
June. After the drill string was positioned $250 \mathrm{~m}$ above the seafloor, the vessel was offset $2.3 \mathrm{nmi}$ on a bearing of $202^{\circ}$ in dynamic positioning mode back to Site U1319. This move was accomplished at an average speed of $0.9 \mathrm{kt}$.

\section{Lithostratigraphy}

Hole U1320A penetrated a thick portion of the sedimentary infill of Brazos-Trinity Basin IV and into the underlying sediments. The $299.6 \mathrm{~m}$ thick sedimentary succession was divided into five lithostratigraphic units based on visual core description and analysis of smear slides (Table T3). Color spectrophotometry data showed only minor variations downhole and were not used to distinguish units. Because parts of the sedimentary succession were incompletely recovered, we used well logs, particularly gamma ray curves, to assist in interpreting lithologies and refining unit boundaries. A summary of the lithostratigraphic column is presented in Figure F2. Figures F3, F4, F5, F6, F7, and F8 illustrate the range of features and facies in each of the lithostratigraphic units, and Figure F9 summarizes the results of smear slide analyses.

\section{Description of lithostratigraphic units}

\section{Unit I}

Interval: Sections 308-U1320A-1H-1, $0 \mathrm{~cm}$, through $1 \mathrm{H}-2,115 \mathrm{~cm}$

Depth: 0-2.65 mbsf

Age: Holocene/(?) late Pleistocene

Lithology: foraminifer-bearing clay

Lithostratigraphic Unit I consists of greenish gray clay with foraminifers and sponge spicules. As estimated from smear slides, the foraminifer concentration is low (probably $<5 \%$ ), but foraminifers are visible to the naked eye on the split core. The lower boundary is defined at the top of the first sand lamina observed downcore.

\section{Unit II}

Interval: Sections 308-U1320A-1H-2, $115 \mathrm{~cm}$, through $17 \mathrm{X}-2,91 \mathrm{~cm}$

Depth: $2.65-137.5 \mathrm{mbsf}$

Age: late Pleistocene

Lithology: sand and mud

Lithostratigraphic Unit II is $134.85 \mathrm{~m}$ thick. The lower boundary is defined at the top of bioturbated foraminifer-bearing clay that corresponds closely with seismic Reflector R30. Unit II consists of $\sim 51 \%$ mud and clay and $49 \%$ sand. The sandy units occur as packages as thick as $10 \mathrm{~m}$, containing thick and medium beds of massive sand. The packages are sep- arated by bioturbated muddy intervals ranging in thickness between 1 and $10 \mathrm{~m}$. The thick sandy units were partly disturbed by the coring process and were very soupy after core splitting, but core recovery was good, particularly with the APC (Fig. F2). Despite the deformation, the thickness of the sands is well preserved, given the good correlation between core and logging data (Fig. F2). Based on arrangement of the sand and mud intervals and/or their sand content, we divided Unit II into five subunits (Fig. F2; Table T3).

\section{Subunit IIA (2.65-27.6 mbsf)}

Lithostratigraphic Subunit IIA consists primarily of fine-grained sand (up to 70\%) occurring in massive beds with graded tops and containing shell fragments, plant debris, and mud clasts (Fig. F3A-F3D). The base of Subunit IIA contains numerous thin laminae and thin beds of very fine to fine sand. The sand beds are organized in three packages that increase in thickness upward within the unit, from $\sim 4 \mathrm{~m}$ thick at the base to $\sim 5 \mathrm{~m}$ thick in the middle and $\sim 8 \mathrm{~m}$ thick at the top. Each sand package has a sharp base and is capped by thin beds and laminae of silt (upward thinning). Individual bed thickness ranges from decimeters to several meters, and the thickest beds were soupy in the cores.

\section{Subunit IIB (27.6-37.8 mbsf)}

Lithostratigraphic Subunit IIB consists of a $10.16 \mathrm{~m}$ thick clay interval that lacks any silt or sand laminae with sharp top and base. Freshly split cores showed ephemeral black mottling that disappeared a few hours after splitting, requiring several millimeters of scraping to reveal the mottling. Rare millimeter-scale silt-filled burrows and small wood fragments occur throughout the unit. A particularly intriguing feature is observed over parts of this interval (Fig. F3E), interpreted as the result of bioturbation or, alternatively, differential oxidation associated with core microcracking.

\section{Subunit IIC (37.76-82.0 mbsf)}

Lithostratigraphic Subunit IIC consists of a $44.24 \mathrm{~m}$ thick interval with high sand content. The top of the unit is defined by a sharp contact with the bioturbated clay above. The upper part of Subunit IIC shows an overall upward-fining and thinning succession from $\sim 43 \mathrm{mbsf}$ to the top of the Subunit at 37.8 mbsf. In this interval we observed thick (1-2 m) beds of sand, silt, and sandy silt that are normally graded and rich in plant debris. These beds are grouped into two packages several meters thick in the upper part of the unit (Fig. F2). Below these two packages is an interval of poor recovery (Cores 308-U1320A-10X 
and $11 \mathrm{X})$. The gamma ray $\log$ indicates the presence of two sand intervals between 75 and 82 mbsf separated by a muddy interval. The base of Subunit IIC is defined at the base of the sand-rich interval interpreted from the gamma ray log at 82 mbsf. This contact corresponds closely with seismic Reflector R20. Subunit IIC consists of four packages of sand intercalated with three clay-rich intervals. With sand content as high as $77 \%$, this interval is the sandiest of the entire succession penetrated in Hole U1320A and corresponds closely with an acoustically transparent interval between seismic Reflectors R10 and R20. The sand packages show overall upward increasing thickness, starting with the basal package at $\sim 2 \mathrm{~m}$ thick, then $\sim 5 \mathrm{~m}, \sim 6 \mathrm{~m}$, and $\sim 14 \mathrm{~m}$ for the uppermost package. The sand beds are characterized by upper fine to lower medium sand. Although very thick beds ( $>1-2$ $\mathrm{m})$ were soupy after splitting the core, they appear massive with no discernible grain size grading (Fig. F3F). Most sand beds are rich in shell fragments and plant debris. Each of the sand packages is capped by clays and thin-bedded silt and very fine sand laminae, grading upward to mottled and bioturbated clay. Contorted bedding occurs locally within the clay-rich package at 57-65 mbsf, possibly related to loading by the upper sand package or to a mass transport deposit (MTD).

\section{Subunit IID (82.0-124.6 mbsf)}

Lithostratigraphic Subunit IID is defined within an interval of relatively poor core recovery (average $=$ $\sim 20 \%$ ), but the combined interpretation of cores and well logs indicates that this subunit is composed of an average of $68 \%$ clay and $32 \%$ sand, mostly within thick sand packages (Fig. F2; Table T3). The recovered sands within Subunit IID are mostly very fine to fine grained with normally graded tops. Abundant plant debris is observed in the thickest sand recovered at 93 mbsf (Fig. F3G), but most of the sand beds recovered are centimeters to decimeters thick. Clay intervals recovered in this subunit are characterized by bioturbation and black mottling, with rare thin silt laminae commonly disrupted by burrowing. Smear slides contain 5\%-10\% organic matter dispersed in the clays and a local presence of dispersed volcanic glass and $\mathrm{CaCO}_{3}$ fragments (Fig. F9).

Based on the gamma ray logs, we interpret two sand packages with sharp bases and gradual upward-thinning and -fining trends at the top (Fig. F2): the lower package is $\sim 3.5 \mathrm{~m}$ thick and the upper package is $\sim 7$ $\mathrm{m}$ thick (see "Downhole measurements"). Similar to Subunit IIC, the sand beds within Subunit IID appear to be grouped into packages separated by bioturbated clays, with overall increasing in thickness uphole (Fig. F2).

\section{Subunit IIE (124.6-137.5 mbsf)}

Lithostratigraphic Subunit IIE consists of an interval dominated by clay ( $90 \%)$ with only two sand beds, one at the base and one in the middle portion of the subunit (Figs. F2, F3). The key distinguishing characteristics of this subunit are the occurrence of beds containing mud clasts of various colors (Fig. F3H), folding, steep erosional contacts (Fig. F3I), and steep apparent bedding dips (Fig. F4). In some intervals (Sections 308-U1320A-16X-6 and 16X-7), we observed "chevron" or "wood-grain" patterns indicative of coring-induced biscuiting of folded or steeply dipping sediment similar to that observed on the Amazon Fan (Flood, Piper, Klaus, et al., 1995). Borehole images in this interval indicate the presence of steeply dipping beds, confirming our interpretation of coring-induced deformation for the "wood-grain" patterns (Fig. F4; "Downhole measurements").

\section{Unit III}

Interval: Sections 308-U1320A-17X-2, $91 \mathrm{~cm}$, through $17 \mathrm{X}-\mathrm{CC}, 20 \mathrm{~cm}$

Depth: 137.50-145.3 mbsf

Age: late Pleistocene

Lithology: foraminifer-bearing clay with ash layer Lithostratigraphic Unit III is a $7.8 \mathrm{~m}$ thick interval consisting of bioturbated clay with variable coloration between greenish gray and brownish gray. The unit is distinct by the presence of foraminifers $(<5 \%)$ over most of the unit. Locally within small burrows and thin discontinuous laminae we observe abundant foraminifer tests and test fragments. Several styles of bioturbation and bioturbation intensity can be discerned on the core face (Fig. F6).

Unit III in Hole U1320A is correlative with lithostratigraphic Unit III at Site U1319 based on the position of seismic Reflector R30, and therefore we expected to encounter the same ash layer encountered in Hole U1319A. After careful inspection and examination of several smear slides, we encountered a thin, discontinuous lens containing $90 \%$ volcanic glass shards at 143.4 mbsf in Section 308-U1319A17X-6 (Fig. F6). The grain size and appearance of the volcanic glass shards are very similar to those encountered in the ash layer in Hole U1319A (Fig. F6).

\section{Unit IV}

Interval: Sections 308-U1320A-17X-CC through $21 \mathrm{X}-1,0 \mathrm{~cm}$

Depth: 145.3-174.4 mbsf

Age: late Pleistocene

Lithology: Clay with thin sand/silt beds

Lithostratigraphic Unit IV is dominated by clay with thin beds of silt and sand. The clays in this interval 
have only minor amounts of silt $(<20 \%)$ and show varying degrees of bioturbation and color changes (Fig. F7A-F7D). Color variations include both light and dark gray clays and black mottles. The color variations are ephemeral and disappeared within a few hours of exposure in the laboratory, particularly the black bands and mottles. Small silt blebs occur within burrow fills dispersed through the interval, which are often enriched in bioclastic components and probably represent bioturbated silt laminae. A few thin-graded beds and laminae of sand and silt occur within this interval (Fig. F7E). Primary sedimentary structures were very disrupted by biscuiting resulting from XCB coring.

The base of this unit is defined from the gamma ray $\log$ within an interval of poor core recovery and corresponds closely with seismic Reflector R40 (Fig. F2). Gamma ray logs indicate the presence of a $\sim 3 \mathrm{~m}$ thick sand and silt interval in Hole U1320A (FMSsonic logging run) that is as thick as $8 \mathrm{~m}$ in Hole U1320B (LWD) (Fig. F2; "Downhole measurements"). We defined the base of Unit IV at the base of the sandy interval in Hole U1320B. Because of the variability in gamma ray response between Holes U1320A and U1320B, which are $20 \mathrm{~m}$ apart, it appears that this boundary represents a dipping erosional surface. The sand content of Unit IV is 23\%, but if we exclude the anomalously thick sand interval interpreted from the gamma ray log at the base, the sand content of Unit IV is only $8 \%$.

\section{Unit V}

Interval: Sections 308-U1320A-21X-0 cm, through $33 \mathrm{X}-\mathrm{CC}, 39 \mathrm{~cm}$

Depth: 174.4-299.6 mbsf

Age: late Pleistocene

Lithology: bioturbated clay

Lithostratigraphic Unit V, spanning to $299.6 \mathrm{mbsf}$ at the base of Hole U1320A, is composed of greenish gray to reddish brown clay (Fig. F8). The clays are punctuated by dark gray to black organic-rich, locally pyritic layers ranging from millimeters to centimeters thick. The greenish gray and reddish brown clays are locally distinct and range from $\sim 10 \mathrm{~cm}$ to several decimeters in thickness (Fig. F8B-F8D). More commonly, these layers are disrupted by burrowing, imparting an overall mottled appearance to the unit. Smear slides show that sediments throughout the unit have a minor component of bioclastic origin, including $\mathrm{CaCO}_{3}$ fragments and foraminifers. Bioclastic sediments are locally enriched within burrow fills and thin laminae (Fig. F9).

The top of Unit $\mathrm{V}$ occurs in an interval of poor core recovery across Cores 308-U1320A-20X and 21X. Based on seismic correlation with Site U1319, we ex- pected to encounter a foraminifer-bearing hemipelagic clay near seismic Reflector R40. Based on the well logs, we tentatively interpret a $\sim 2 \mathrm{~m}$ thick hemipelagic clay at the top of Unit $\mathrm{V}$ at a gamma ray peak observed in the wireline log in Hole U1320A (see "Downhole measurements"). It is possible that this hemipelagic clay interval is eroded in Hole U1320B (Fig. F2).

\section{Interpretation of lithostratigraphy} Interpretation by unit

Lithostratigraphic Unit I is dominated by hemipelagic sedimentation. Lacking silt and sand beds, it represents a cessation of turbidity current influx into Brazos-Trinity Basin IV during the present interglacial period.

Lithostratigraphic Unit II, with an average of $49 \%$ sand beds, represents the main period of turbidity current influx into Brazos-Trinity Basin IV and corresponds to the major portion of the basin infill. It consists of a series of sand packages with sharp bases, with medium to thick fine-sand beds. Bioturbated clays at the top of each sand package may represent a pause in turbidite sedimentation within the basin or lower accumulation rates laterally distal from the main depocenters of sand in the basin.

Lithostratigraphic Unit III is dominated by hemipelagic sedimentation and represents a pause of turbidity current flux into the basin. The top of lithostratigraphic Unit III corresponds closely with seismic Reflector R30. The unit straddles an ash layer, tentatively correlated with ash Layer Y8 dated at 84 ka (Mallarino et al., in press; Drexler et al., 1980).

Lithostratigraphic Unit IV corresponds to the lowermost part of the onlapping fill of Brazos-Trinity Basin IV between seismic Reflectors R30 and R40. Immediately above the unconformity marking the base of the onlapping fill (seismic Reflector R40), there is an $8 \mathrm{~m}$ thick sand interval in Hole U1320B compared to a $\sim 2-3 \mathrm{~m}$ thick sand in Hole U1320A, $20 \mathrm{~m}$ away. This difference is interpreted to result from a local erosional surface, perhaps associated with a channel with an apparent dip of $\sim 14^{\circ}$. The remainder of lithostratigraphic Unit IV is interpreted to be the result of low-density turbidity currents forming thin beds and silt laminae and a few thin sandy turbidites. The basal part of lithostratigraphic Unit IV is silty, and the number of distinct turbidite beds and laminae increases upward. Bioturbated clays, representing a reduction in the influx of turbidity currents into the basin, cap the succession.

Lithostratigraphic Unit V is a thick and monotonous interval dominated by bioturbated clays with rare foraminifers and lacking obvious evidence of turbid- 
ity current input such as silt and sand laminae. The faint color banding (greenish gray and black) of the organic-rich clays is interpreted to represent fluctuations in organic matter and siliciclastic input. The general lack of coarse (silt and sand) grains suggests deposition from muddy river plumes or from distal turbidites spilling from adjacent intraslope basins. Lithostratigraphic Unit V correlates with lithostratigraphic Unit VI described at Site U1319. The uppermost part of lithostratigraphic Unit $\mathrm{V}$ in Hole U1320A was not recovered and occurs immediately below a sandy interval identified in the well logs.

\section{Summary interpretation}

Hole U1320A penetrates a thick portion of BrazosTrinity Basin IV and contains a nearly complete lithostratigraphic record of the onlapping fill of the basin above seismic Reflector R40 and of the conformable succession below. Ash Layer Y8, together with high-resolution seismic data, allows for excellent correlation of lithostratigraphic units between the basin margin (Site U1319) and the basin center (Site U1320). The underlying succession is represented by bioturbated clays, which are likely derived from river plumes and/or distal turbidity currents. The basin began to fill soon after the last interglacial, at $125 \mathrm{ka}$. This lower portion of the basin fill is the result of dominantly muddy flows, probably spilling from the basins updip. The notable exception is that the very onset of this basin fill is represented by a thick sandy interval, which contrasts with the remainder of lithostratigraphic Unit IV, characterized mostly by muddy turbidites. The early onset of turbidte infill is then interrupted by hemipelagic deposition that draped the entire basin (lithostratigraphic Unit III) between $\sim 90$ and $\sim 47 \mathrm{ka}$, according to the age model of Mallarino et al. (in press) and to the shipboard age determination (see "Biostratigraphy"). A clay-rich MTD occurs immediately above the hemipelagic interval containing clasts of foraminifer-bearing clay possibly derived from the underlying hemipelagic units. This MTD is $12.9 \mathrm{~m}$ thick in Hole U1320A but thickens considerably laterally away and is the result of mass wasting of the basin flanks (Winker, 1996).

The overlying $132.2 \mathrm{~m}$ represents the main portion of the basin infill, containing a series of sandy turbidite packages interbedded with bioturbated clays and muds and a few thin muddy MTD beds (Subunits IIA-IID) (Fig. F2). The sand packages consist of medium- to thick-bedded turbidites, mostly containing massive fine-sand beds with sharp bases and upward-thinning tops capped by 1-10 $\mathrm{m}$ of bioturbated clay. These packages represent lateral shifting of channels and lobes within the basin as indicated by seismic data (Winker, 1996; Beaubouef et al., 2003). The bioturbated muds between sand packages may represent distal deposition resulting from lobe shifts and/or reduced sedimentation rates throughout the basin. Some of these muddy intervals can be correlated laterally across the basin (e.g., Subunit IIB below seismic Reflector R10).

Within the onlapping fill above seismic Reflector R40, both sand content and thickness of turbidite packages increase upward. This is the result of increased sediment flux into Brazos-Trinity Basin IV, a consequence of lowering of sea level since the last interglacial and/or progressive increase in the spilling of turbidity currents from Brazos-Trinity Basin II updip.

\section{Biostratigraphy}

Calcareous nannofossils and planktonic foraminifers are rare to common with good preservation except in Samples 308-U1320A-4H-CC, 24-29 cm, 15X-CC, $19-24 \mathrm{~cm}$, and 19X-CC, $42-47 \mathrm{~cm}$, where foraminifers are barren. Below Core 308-U1320A-26X, both nannofossil and foraminifer abundances decline rapidly.

We identified the nannofossil Emiliania huxleyi Zone and a transitional zone, as well as planktonic foraminifer Zones $\mathrm{W}, \mathrm{X}$, and Y largely based on analyzing core catcher samples from Hole U1320A (Fig. F10). The results indicate that, similar to Site U1319, sediments recovered at Site U1320 are of late Pleistocene to Holocene age and record deposition over approximately the last $150 \mathrm{k} . \mathrm{y}$. Compared to Site U1319, however, the sedimentary succession at Site U1320 is greatly expanded. Because of incomplete core recovery and rare nannofossils and planktonic foraminifers in some samples, our biostratigraphic data cannot confirm the completeness of the sediment record.

Benthic foraminifers, especially in samples from the lower part of Hole U1320A, are dominated by species living in low-oxygen, nutrient-rich environments. Frequent neritic benthic foraminifers and reworked Cretaceous nannofossils found in samples from the upper $120 \mathrm{~m}$ of the hole suggest downslope transport by turbidites.

\section{Calcareous nannofossils}

We examined all core catcher samples and additional samples from Sections 308-U1320A-17X-5 and 17X-6 for calcareous nannofossils. All samples yielded rare to abundant nannofossil assemblages, with a general reduction of abundance toward the bottom of the hole. Samples from Core 308-U1320A-17X and 
above contain very abundant nannofossils, but downhole from Sample 18X-CC, $32-37 \mathrm{~cm}$, their abundance varies from abundant to rare. Preservation is good to moderate throughout the section. Samples with poorly preserved nannofossils are typically coarse grained with low overall abundance. Nannofossil assemblages contain in situ and reworked species. The most dominant in situ species are E. huxleyi, Gephyrocapsa aperta, and Gephyrocapsa ericsonii. Gephyrocapsa oceanica is always more abundant than Gephyrocapsa caribbeanica, although both rarely attain $5 \%$ of the total abundance. The majority of reworked species are Cretaceous in age ( $>99 \%)$, and they occur throughout the section (Figs. F11, F12).

Based on the nannofossil stratigraphic subdivision of Hine and Weaver (1998), we were able to recognize two main zones (QAZ1 E. huxleyi Acme and QAZ2 Transitional Zones) for the sediment sequence recovered at Site U1320. Based on the distribution of different groups of nannofossils we can also distinguish Subzones A-C within the QAZ2 Transitional Zone, similar to the results from Site U1319.

\section{QAZ1 E. huxleyi Acme Zone}

We identified this zone in Samples 308-U1320A-1HCC, $7-12 \mathrm{~cm}$, through $17 \mathrm{X}-5,5 \mathrm{~cm}$, on the dominant abundance of E. huxleyi (70\% or more). According to Berggren et al. (1995), the first occurrence datum of E. huxleyi acme is at $90 \mathrm{ka}$. Reworked Cretaceous species are more abundant relative to the lower part of the hole (QAZ2 Transitional Zone). Significant reworking of nannofossil assemblages from the QAZ2 Transitional Zone can be traced in Sample $308-U 1320 A-12 X-C C, 15-20 \mathrm{~cm}$. This is interpreted as resulting from increased turbiditic activity at this time.

\section{QAZ2 Transitional Zone}

This zone was distinguished in Samples 308U1320A-17X-5, $145 \mathrm{~cm}$, through 33X-CC, 22-26 cm. It is characterized by the dominance of $G$. aperta- $G$. ericsonii. Together, these two species constitute $>90 \%$ of the overall abundance. Subzones, A, B, and C, are distinguished based on the abundance variations of these two species.

\section{Subzone A}

Subzone A, an uppermost subzone of the QAZ2 Transitional Zone, is found in Samples 308-U1320A-17X$5,145 \mathrm{~cm}$, through $17 \mathrm{X}-\mathrm{CC}, 49-54 \mathrm{~cm}$. It is defined based on an overall abundance of $\sim 100,000$ specimens per 100 fields of view of G. aperta-G. ericsonii and the absence of E. huxleyi. G. oceanica-G. caribbeanica complex is common to abundant, as well as
Scapholithus fossilis and Umbilicosphaera spp. Section 308-U1320A-17X-5, $145 \mathrm{~cm}$, is now identified as representing the top of the QAZ2 Transitional Zone at $90 \mathrm{ka}$, which is at odds with the position of ash Layer Y8 2.5 m upsection (84 ka) (Mallarino et al., in press). Further scanning electron microscope studies are needed to clarify if small-sized specimens of $E$. huxleyi are not detected using light microscopes available onboard.

\section{Subzone B}

This subzone is distinguished based on the common overall abundance of G. aperta-G. ericsonii. Subzone B is defined in Samples 308-U1320A-18X-CC, 32-37 $\mathrm{cm}$, through 27X-CC, $25-30 \mathrm{~cm}$.

\section{Subzone C}

Subzone $\mathrm{C}$ is defined by the dominant occurrence of reworked Cretaceous species to $>50 \%$ of the total abundance. This subzone has rare in situ species including G. aperta-G. ericsonii. Subzone $\mathrm{C}$ is defined in Samples 308-U1320A-28X-CC, 38-43 cm, through $33 \mathrm{X}-\mathrm{CC}, 22-26 \mathrm{~cm}$.

All nannofossil stratigraphic subdivisions correlate well with the results from Site U1319.

\section{Planktonic foraminifers}

The overall preservation of foraminifers in Hole U1320A is good to excellent. However, planktonic foraminifers are common to abundant only in Samples 308-U1320A-12X-CC, 17X-CC, and 22X-CC through $25 \mathrm{X}-\mathrm{CC}$ but are rare to trace in other samples. Reworked specimens common in samples from above Core 308-U1320A-14X are considered to be a result of turbidite deposition.

As at Site U1319 and other neighboring sites described recently by Mallarino et al. (in press), the planktonic foraminifer assemblage found in samples from Site U1320 is dominated by Globigerinoides ruber (both the pink and white forms) with lesser amounts of Globigerinoides sacculifer, Globigerinoides conglobatus, Neogloboquadrina dutertrei, Globorotalia truncatulinoides, Globorotalia menardii, Globorotalia tumida, Globorotalia flexuosa (older than $68 \mathrm{ka}$ ), Globorotalia inflata (older than $10 \mathrm{ka}$ ), Globorotalia crassaformis, Globigerinella siphonifera, Orbulina universa, Globigerina bulloides, Globigerina falconensis, and Pulleniatina obliquiloculata. Other taxa, such as Globigerinita glutinata, Hastigerina pelagica, and Globigerinella calida, are rare.

Planktonic foraminifer assemblage Zones $\mathrm{W}, \mathrm{X}$, and $\mathrm{Y}$ were identified, suggesting that the sediment recovered from Hole U1320A was deposited mainly during the last 180 k.y. (Fig. F13). Holocene Zone Z, 
characterized by $G$. menardii without $G$. inflata, is not recognized, probably because its components have been diluted in sands from the uppermost core catcher sample from Hole U1320A. The absence of both $G$. menardii and G. inflata from Sample 308U1320A-1H-CC, 7-12 cm (4.54 mbsf), may indicate a position near the Zone $\mathrm{Y} / \mathrm{Z}$ boundary. The interval from Cores 308-U1320A-3H through $14 \mathrm{X}$ contains mostly reworked specimens associated with turbidite deposition, thus hampering a proper subdivision of Zone Y. Semiquantitative planktonic foraminifer data are presented in Table T4.

\section{Zone $\mathrm{Y}$}

From Cores 308-U1320A-2H through 16X the planktonic foraminifer assemblage is dominated by $\mathrm{G}$. ruber and G. inflata. G. menardii and many other warmwater species found in several samples from this interval are obviously reworked because these samples contain abundant plant debris, mica, and shallowwater benthic foraminifers that indicate a nearshore origin. In addition, the presence of many broken specimens and relatively poor to moderate preservation suggests that these were transported by turbidites. The possibility of reworking diminishes our ability to use the last occurrence of $G$. flexuosa as a correlation datum at $68 \mathrm{ka}$. Pending further studies, the base of Zone $\mathrm{Y}$ is tentatively placed at Sample 308-U1320A-16X-CC, 35-40 cm (136.1 mbsf). According to lithostratigraphic results, ash Layer Y8 occurs at 143.42 mbsf (see "Lithostratigraphy").

\section{Zone $\mathrm{X}$}

Zone X was recognized only in Sample 308-U1320A17X-CC, $49-54 \mathrm{~cm}$ (145.6 mbsf). It contains abundant warm-water planktonic foraminifers typified by G. tumida, G. flexuosa, G. crassaformis, G. truncatulinoides, G. menardii, G. siphonifera, N. dutertrei, P. obliquiloculata, O. universa, G. ruber, G. sacculifer, G. conglobatus, and $G$. falconensis. The cool-water species $G$. inflata is absent from this zone. The downhole distribution of this zone is hampered by a rare assemblage immediately below Core 308-U1320A$17 \mathrm{X}$ and by no recovery in Cores $20 \mathrm{X}$ (lower part) and 21X (169-185 mbsf). Seismic correlation with Site U1319 suggests that hemipelagic intervals with abundant microfossils may occur in this interval of low core recovery (see "Lithostratigraphy").

\section{Zone W}

Zone W, characterized by G. inflata without G. menardii and other warm-water species, can be assigned to core catcher samples from Core 308-U1320A-18X and below. If the missing interval between 169 and 185 mbsf bears a Zone X warm-water assemblage as mentioned above, then Cores 308-U1320A-18X through 20X may still lie in Zone X because the Subzone $\mathrm{X} 4$ assemblage is similar to Zone $\mathrm{W}$ in having mainly cool-water species, especially $G$. inflata. Zone $\mathrm{W}$ cannot be subdivided because of rare planktonic foraminifers in all samples from Cores 308-U1320A24X through 33X.

\section{Benthic foraminifers}

Benthic foraminifers are rare to common in core catcher samples from Hole U1320A. Preservation in most samples is good to very good except in displaced or reworked specimens. The assemblages include mainly calcareous taxa and only few species and specimens of agglutinated and other taxa. The benthic foraminifers found generally represent wellknown neritic to deepwater taxa that prefer oxygenpoor, nutrient-rich environments. Semiquantitative benthic foraminifer data listed in Table T5 enabled the recognition of three assemblages: a mixed assemblage with deep- and shallow-water species resulting from turbidites, a Laticarinina assemblage representing a normal bathyal association, and a BolivinaBulimina assemblage preferring low-oxygen, highnutrient environments.

\section{Mixed assemblage (within Zone $Y$, latest Pleistocene)}

The coexistence of many inner neritic species and typical bathyal forms was found in samples from Cores 308-U1320A-3H through $14 \mathrm{X}$, a result of frequent turbidite deposits (see "Lithostratigraphy"). The inner neritic species are represented by Ammonia beccarii, Elphidium spp., Florilus spp., and Quinqueloculina spp. A. beccarii and most species of Elphidium live mainly in lagoon to inner shelf environments, and their mixing with Laticarinina pauperata, Sphaeroidina bulloides, Cibicidoides spp., and other bathyal species (as well as warm-water planktonic foraminifers from Zone $\mathrm{X}$ ) indicates downslope transport. Abundant plant debris also confirms a nearshore origin for the major part of the sediment from this interval.

\section{Laticarinina assemblage (late Pleistocene MIS 5)}

This is a well-diversified assemblage found only in Sample 308-U1320A-17X-CC, 49-54 cm, characterized by few or common occurrences of $L$. pauperata, Cibicidoides wuellerstorfi, Uvigerina hispidicostata, Stilostomella lepidula, Cibicidoides spp., Sigmoilopsis schlumbergeri, Pyrgo spp., Sphaeroidina bulloides, Lenticulina spp., and Pullenia spp. The presence of L. pauperata and $P$. wuellerstorfi indicate middle to lower bathyal paleodepths greater than $1000 \mathrm{~m}$. The absence of shallow-water forms from this sample also 
confirms a normal lower bathyal setting. Some deepwater species including $L$. pauperata in Cores 308U1320A-6H, 7H, 12X, and 13X appears to have been displaced or reworked in the "mixed assemblage" due to turbidites, as described above.

\section{Bolivina-Bulimina assemblage (late Pleistocene MIS 2-4 and MIS 6)}

This is the same assemblage found in the lower part of Site U1319 and is characterized by small thinshelled species including Bolivina spissa, Bolivina spp., Bulimina aculeata, Uvigerina spp., Fursenkoina bradyi, and Chilostomella ovoidea. Other species that may also occur are Quinqueloculina spp., Gyroidina spp., and Oridorsalis tenera. This infauna-dominated assemblage occurs in samples from Cores 308U1320A-18X through 33X and indicates upper slope to lower bathyal depths greater than $400 \mathrm{~m}$, where oxygen was low, perhaps due to rapid sediment accumulation.

Fluctuations in the relative abundance of such taxa as Bolivina spp., Bulimina spp., and Fursenkoina bradyi, as observed in samples from Cores 308U1320A-20X through 29X (Fig. F14), may reflect cyclic changes in sedimentation rates and/or bottom circulation.

\section{Age model and sedimentation rates}

The age models developed during the expedition are preliminary. Biostratigraphic dating of Pleistocene sediments is notoriously difficult, and we had to rely on several assumptions to constrain age models and sedimentation rates. In the case of Site U1320, we took into consideration biostratigraphic, lithostratigraphic (ash layer event), and magnetostratigraphic tie points (Table T6). The uppermost $140 \mathrm{~m}$ at Site $\mathrm{U} 1320$ is composed of sandy sediment and thus lacks reliable magnetostratigraphic tie points. The only reliable chronostratigraphic datums obtained are the last occurrence (LO) of G. inflata at $9.29 \mathrm{mbsf}$ and the presence of ash Layer Y8 at 143.42 (Fig. F15; Table T6). The LO of G. flexuosa was identified at 95.59 mbsf (Fig. F15), but it occurs in a turbidite interval and appears to be reworked. We also note a minor inconsistency between the stratigraphic depth of ash Layer Y8 dated at $84 \mathrm{ka}$ and the depth of the FO of the E. huxleyi acme dated at $90 \mathrm{ka}$; the younger datum is stratigraphically below the older datum. We argue that this minor discrepancy is due to poor calibration of the age of the E. huxleyi acme, and we decided to use the well-calibrated radiochronologic age of the ash layer instead. Linking the LO of G. inflata with ash Layer Y8 in our age model yields an average sedimentation rate from 143.43 mbsf to 9.29 mbsf of $1.81 \mathrm{~m} / \mathrm{k} . y$. (Fig. F15). Below 143.42 mbsf, no reliable markers exist. The lower section of lithostratigraphic Unit II and Unit III, from the lower part of Core 308U1320A-17X to 16X, appears to be condensed when looking at the magnetostratigraphic tie points, in particular MTP7, with respect to the position of the ash layer (Fig. F15; Table T6). Sedimentation rates in this interval could be as low as $0.2 \mathrm{~m} / \mathrm{k}$.y. No stratigraphic datums have been recorded below 148.0 mbsf at Site U1320, but since Helicosphaera inversa is consistently absent we assume that the oldest sediment recovered is younger than the $\mathrm{LO}$ of $H$. inversa $(150 \mathrm{ka})$. If we assume the age of the last recovered sediment to be $150 \mathrm{ka}$, the minimal sedimentation rate between 148.0 and $299.44 \mathrm{mbsf}$ is $2.6 \mathrm{~m} / \mathrm{k} . \mathrm{y}$. In view of the many uncertainties outlined above, a more rigorous postcruise study is needed to confirm the preliminary interpretations outlined in this paragraph.

\section{Paleomagnetism}

All cores from Hole U1320A were measured on the pass-through cryogenic magnetometer using a peak alternating-field (AF) demagnetization field of 20 $\mathrm{mT}$, with the exception of the unconsolidated sandy intervals between 42 and 56 mbsf (Table T7). The Tensor tool was used to orient Cores 308-U1320A-4H through $9 \mathrm{H}$. The drilling system was switched from APC to XCB beginning with Core 308-U1320A-10X (see "Summary of operations"). Low core recovery in Cores 308-U1320A-8H through $14 \mathrm{X}$ as well as $20 \mathrm{X}$ and $21 \mathrm{X}$ resulted in measurement gaps in natural remanent magnetization intensity after $20 \mathrm{mT}$ demagnetization $\left(\mathrm{NRM}_{20 \mathrm{mT}}\right)$, and in declination, inclination, and magnetic susceptibility ( $\kappa)$ data.

\section{Paleomagnetic intervals}

Hole U1320A was divided into three intervals based on paleomagnetic measurements (Fig. F16; Table T8).

\section{Interval 1 (0-70 mbsf)}

Paleomagnetic Interval $1 \mathrm{NRM}_{20 \mathrm{mT}}$ intensity values range between 0.00 and $0.012 \mathrm{~mA} / \mathrm{m}$ (Fig. F16A) and are similar to those observed in Hole U1319A. Deviations from the normal polarity trend of the Brunhes Chron were observed in declination and inclination. The abnormal values occur at 35-70 mbsf for declination and 40-60 mbsf for inclination within Cores 308-U1320A-5H through 8H (Fig. F16B, F16C). These remanence direction variations may indicate a polarity excursion corresponding to the geomagnetic Lake Mungo Event (denoted on Fig. F16C) dated at $\sim 30 \mathrm{ka}$ for the Gulf of Mexico (Freed and Healy, 1974; Stupavsky and Gravenor, 1984; Cisowski and 
Hall, 1997). However, lithostratigraphic observations (see "Lithostratigraphy") describe the sections containing the excursion as interbedded sand and mud beds. Therefore, we caution that a change in lithology could also explain this change, and that detailed onshore paleomagnetic investigations on discrete samples are needed.

\section{Interval 2 (117-170 mbsf)}

Paleomagnetic Interval 2 has a slightly higher mean $\mathrm{NRM}_{20 \mathrm{mT}}$ intensity value of $\sim 0.013 \mathrm{~mA} / \mathrm{m}$, but the values range from 0.002 to $0.030 \mathrm{~mA} / \mathrm{m}$. Below 117 mbsf (below lithostratigraphic Subunit IID), uncorrected declination records relatively stable directions of $\sim 50^{\circ}$ (Fig. F16B). Inclination data show characteristic normal polarities typical for the Brunhes Chron (Fig. F16C).

\section{Interval 3 (185 mbsf-TD)}

$\mathrm{NRM}_{20 \mathrm{mT}}$ values in paleomagnetic Interval 3 average $\sim 0.01 \mathrm{~mA} / \mathrm{m}$. Declination data in this interval (lithostratigraphic Unit V) show relatively stable directions, similar to those in Interval 2 (Fig. F16B). Inclination data show normal polarity directions.

\section{Magnetostratigraphy}

$\mathrm{NRM}_{20 \mathrm{mT}}$ intensity, $\kappa$, and bulk density values in Hole U1320A (Fig. F17) are comparable to those observed in Hole U1319A. However, the upper section (lithostratigraphic Units I-IV) is $170 \mathrm{~m}$ thick at Site U1320, whereas the equivalent interval at Site U1319 is only $30 \mathrm{~m}$ thick. Despite this difference in sedimentation rates, several magnetostratigraphic tie points (MTPs) were correlated using $\mathrm{NRM}_{20 \mathrm{mT}}$ intensity, $\kappa$, and bulk density data (see "Paleomagnetism" in the "Methods" chapter for details). In Hole U1320A, paleomagnetic Interval 1 is comparable to the upper part of paleomagnetic Interval 1 in Hole U1319A. MTP2 and MTP3 were therefore tentatively correlated to MIS 3.3 and 4.2 (Bassinot et al., 1994). Because of poor core recovery between 70 and 117 mbsf (just below Interval 1), the interpretation of these two tie points is uncertain. MTP5-MTP7 in Interval 2 are correlated to MIS 5.2-5.4, based in part on the position of ash Layer Y8 (see "Lithostratigraphy"). The second gap in core recovery between 170 and 185 mbsf makes exact determination of the MIS 5.5 termination and onset of MIS 6 impossible at this site. Within Interval 3 (185 mbsf to TD), several peaks correlate across $\mathrm{NRM}_{20 \mathrm{~m}}$ intensity, $\kappa$, and bulk density data. These are identified as MTP10-MTP12 correlative with the previously identified peaks in Hole U1319A.

\section{Geochemistry and microbiology}

\section{Inorganic geochemistry}

\section{Interstitial water geochemistry}

Interstitial water chemistry results are listed in Table T9 and shown in Figures F18, F19, F20, and F21.

Alkalinity varies from 3.05 to $15.99 \mathrm{mM}$ (Table T9). Alkalinity rapidly increases from $4.77 \mathrm{mM}$ near the seafloor to a maximum of $15.99 \mathrm{mM}$ at $20 \mathrm{mbsf}$ and then decreases to $5.28 \mathrm{mM}$ at $121 \mathrm{mbsf}$. The depth of 150 mbsf is marked by an alkalinity maximum of $10.27 \mathrm{mM}$. Below this depth, alkalinity remains constantly low at $\sim 4 \mathrm{mM}$ (Fig. F18). The $\mathrm{pH}$ of the interstitial water varies between 7.09 and 7.84. In general, $\mathrm{pH}$ values are highest (>7.5) above 150 mbsf. The 150-250 mbsf interval is characterized by lower $\mathrm{pH}$ values, as low as 7.09. Below this interval, slightly higher $\mathrm{pH}$ values (7.37-7.54) are recorded (Fig. F18).

Salinity varies between 3.3 and 3.6 parts per hundred (pph) (Table T9). A significant downhole decrease in salinity is observed from the seafloor to $\sim 30 \mathrm{mbsf}$. Below this depth, salinity increases from the minimum value of 3.3 to $3.5 \mathrm{pph}$ at $\sim 70$ mbsf. Below 70 mbsf, salinity shows limited variation between 3.4 and 3.5 pph (Fig. F18). Interstitial water chlorinity varies from 547 to $593 \mathrm{mM}$ with a slight increase downhole (Fig. F18).

The dissolved $\mathrm{SO}_{4}{ }^{2-}$ profile dramatically decreases from $24.4 \mathrm{mM}$ at the seafloor to $\sim 0.6 \mathrm{mM}$ at $21 \mathrm{mbsf}$. In the interval $28-63 \mathrm{mbsf}, \mathrm{SO}_{4}^{2-}$ concentrations remain low at $0.6-2.7 \mathrm{mM}$ and then increase to slightly higher values of $2.1-6.8 \mathrm{mM}$ downhole to the bottom of the core (Fig. F19). The calculated sulfate/methane interface (SMI) depth is 22 mbsf. Dissolved $\mathrm{NH}_{4}{ }^{+}$concentrations generally increase from $132 \mu \mathrm{M}$ at the seafloor to a maximum of $3816 \mu \mathrm{M}$ at 92 mbsf. Concentrations then remain constantly high at $\sim 2000-3000 \mu \mathrm{M}$ downhole to the bottom of the hole (Fig. F19). Dissolved $\mathrm{PO}_{4}{ }^{3-}$ concentrations vary from 0.7 to $68.1 \mu \mathrm{M}$, with maximum values occurring at shallow depths between 14 and 21 mbsf. Below 100 mbsf, $\mathrm{PO}_{4}{ }^{3-}$ concentrations are only several micromolar with one exception $(32.4 \mu \mathrm{M})$ at 150 mbsf. Interstitial water data also show elevated concentrations of dissolved silica $\left(\mathrm{H}_{4} \mathrm{SiO}_{4}\right)$ from 95 to $609 \mathrm{nM}$. Higher silica concentrations occur at shallow depths, with a maximum at 21.5 mbsf. Silica decreases slightly downhole (Fig. F19).

Concentrations of $\mathrm{Na}^{+}$and $\mathrm{Mg}^{2+}$ are slightly lower than seawater values $\left(\mathrm{Na}^{+}{ }_{\mathrm{sw}}=480 \mathrm{mM}, \mathrm{Mg}^{2+}{ }_{\mathrm{sw}}=54\right.$ $\mathrm{mM}$ ) and decrease slightly in the uppermost 40 mbsf. Values then remain nearly constant downhole (Fig. F20). $\mathrm{Ca}^{2+}$ concentrations generally decrease to 
$\sim 40 \mathrm{mM}$ at shallow depths (uppermost $40 \mathrm{mbsf}$ ), which is lower than seawater value $(10.55 \mathrm{mM})$. In the interval between 40 and 140 mbsf, $\mathrm{Ca}^{2+}$ contents are constantly low. Below this depth, concentrations slightly increase to $10-12 \mathrm{mM}$ to the bottom of the cored section (Fig. F20). Concentrations of $\mathrm{K}^{+}$generally decrease downhole from nearly seawater value (10.44 mM) at the seafloor to a minimum of 3-4 mM at the bottom of the cored section (Fig. F20).

Concentration-depth profiles for $\mathrm{B}^{3+}, \mathrm{Ba}^{2+}$, and $\mathrm{Fe}^{2+}$ define two distinct higher-concentration zones, one shallow at 20-40 mbsf, corresponding to the upper part of lithostratigraphic Unit II, and another at 160180 mbsf, corresponding to the lower part of lithostratigraphic Unit IV (Fig. F21). $\mathrm{Li}^{+}$concentrations decrease similarly to sulfate concentrations at shallow depths and reach a minimum at $\sim 40$ mbsf. From 60 to $130 \mathrm{mbsf}, \mathrm{Li}^{+}$contents increase from 11.78 to $28.04 \mu \mathrm{M}$. Below this depth, a general decreasing trend for $\mathrm{Li}^{+}$is apparent (Fig. F21). Sr ${ }^{2+}$ contents show a general decrease to $\sim 70 \mu \mathrm{M}$ at shallow depths (uppermost $40 \mathrm{mbsf}$ ), slightly lower than seawater value $\left(\mathrm{Sr}^{2+}{ }_{\text {sw }}=87 \mu \mathrm{M}\right) . \mathrm{Sr}^{2+}$ concentrations remain low between 40 and 140 mbsf. Below this depth, $\mathrm{Sr}^{2+}$ values slightly increase to $100-120 \mu \mathrm{M}$ to the bottom of the cored section (Fig. F21). $\mathrm{Mn}^{2+}$ concentrations in interstitial water show a similar trend to sulfate values, with a dramatic decrease from $145.4 \mu \mathrm{M}$ at the seafloor to $1.94 \mu \mathrm{M}$ at 30 mbsf. Below this depth, $\mathrm{Mn}^{2+}$ contents remain extremely low $(<4 \mu \mathrm{M})$, but higher values are observed at $131 \mathrm{mbsf}(18.03 \mu \mathrm{M})$ and in the interval from 168 to 176 mbsf $(5.78-9.82 \mu \mathrm{M})$ (Fig. F21).

In summary, rapid changes in interstitial water chemistry profiles occur at shallow depths down to $40 \mathrm{mbsf}$, corresponding to the upper part of lithostratigraphic Unit II. The decrease in $\mathrm{SO}_{4}{ }^{2-}$ concentrations coincides with a concomitant increase in alkalinity and decreases in $\mathrm{Mn}^{2+}, \mathrm{Ca}^{2+}, \mathrm{Mg}^{2+}, \mathrm{Sr}^{2+}$, and $\mathrm{Li}^{+}$ concentrations. These downhole variations may reflect a combination of processes, including rapid anaerobic degradation of organic matter, redox pathways, and diagenetic carbonate precipitation at shallow depths (e.g., Gieskes, 1983; Baker and Burns, 1985).

\section{Solid-phase chemistry}

Initial results for total inorganic carbon (TIC), calcium carbonate $\left(\mathrm{CaCO}_{3}\right)$, total organic carbon (TOC), total nitrogen, molar ratio of organic carbon to total nitrogen $(\mathrm{C} / \mathrm{N})$, and total hydrogen analyses on sediment squeeze cakes are listed in Table T10 and presented in Figure F22. TIC contents range from 0.07 to $3.14 \mathrm{wt} \%$ (average $=1.46 \mathrm{wt} \%$ ). Inorganic carbon concentrations initially decrease to $<0.5 \mathrm{wt} \%$ within the upper $13.5 \mathrm{mbsf}$ and then steadily increase to 2.5 $\mathrm{wt} \%$ at TD.

TOC contents range $0.03-1.99 \mathrm{wt} \%$ (average $=0.53$ $\mathrm{wt} \%)$. The results of $0 \mathrm{wt} \%$ for the sediment intervals collected at 13.5, 232.9, and 68.8 mbsf are artifacts of the method used to calculate TOC (where TOC $=$ TC - TIC) and are not included in the data analysis. TOC contents remain relatively constant throughout the hole with exception of maxima at 14.04, 167.8, and 201.3 mbsf. The maximum concentration (1.99 wt\%) occurs below the sulfate reduction zone.

Nitrogen contents of the sediments range between 0.09 and $0.26 \mathrm{wt} \%$ (average $=0.16 \mathrm{wt} \%$ ). Hydrogen concentrations of the sediments range between 0.06 and $1.14 \mathrm{wt} \%$ (average $=0.71 \mathrm{wt} \%$ ). The total nitrogen and hydrogen curves exhibit greater downhole variability than observed in Hole U1319A. The sawtooth shape of both profiles terminates at $\sim 100$ mbsf, where concentrations approach near-uniform concentrations.

Molar $\mathrm{C} / \mathrm{N}$ ratios range from 0.3 to 12.35 and average 4.21 (omitting results from 13.5, 232.85, and $68.8 \mathrm{mbsf}$ ). The considerable variability in the ratio trend can be described in three subsections of the hole. The ratio within the upper $80 \mathrm{mbsf}$ is variable with four minima at or near zero (calculations explained above). $\mathrm{C} / \mathrm{N}$ ratios are near constant values of 3.2 from 79.3 to 159.7 mbsf. The ratio rises to 7.5 below $167.8 \mathrm{mbsf}$ and then declines in a sawtooth fashion to a value of 3.2 at TD.

\section{Solid-phase initial interpretations}

Trends in data correspond to locations of seismic Reflectors R10, R20, R30, R40, and R50 (Fig. F22). Peaks occur for TIC, $\mathrm{CaCO}_{3}$, TOC, nitrogen, C/N, and hydrogen at seismic Reflector R10, and concentration minima occur directly above seismic Reflector R20. Elevated inorganic carbon concentrations are also found at seismic Reflector R30, coincident with foraminifer-bearing clay of lithostratigraphic Unit III. TOC peaks occur across seismic Reflectors R40 and R50.

The average $\mathrm{C} / \mathrm{N}$ ratio of 4.21 is indicative of organic matter derived primarily from algal material (Fig. F22) or the presence of inorganic nitrogen. Ratios are most variable within the sand and mud of lithostratigraphic Unit II and the bioturbated clays of Unit V.

\section{Organic geochemistry}

\section{Hydrocarbon gas composition}

The vertical distribution of headspace methane concentrations is shown in Figure F23. The rapid increases in methane concentrations begin with the 
disappearance of sulfate (Fig. F24). The calculated SMI depth is 22 mbsf. This inverse correlation suggests that methane results from methanogenesis, which is inhibited in the presence of sulfate. The predominant hydrocarbon found at Site U1320 was methane. Concentrations of hydrocarbon gas components are shown in Table T11. Only very minor amounts of ethane $(<1.9 \mathrm{ppmv})$ and ethylene $(<0.6$ ppmv) were detected in a few samples. No higher hydrocarbons are detectable at Site U1320. When interpreting $\mathrm{C}_{1} / \mathrm{C}_{2}$ ratios, one should consider that minor amounts of $\mathrm{C}_{2}, \mathrm{C}_{3}, \mathrm{C}_{4}$, and $\mathrm{C}_{5}$ compounds can also be generated in situ during early (low temperature) diagenesis of organic matter (e.g., Kvenvolden and Barnard, 1983). $C_{1} / C_{2}$ ratios at Site U1320 are generally high, suggesting a biogenic origin of the methane from in situ microbial activities or hydrogeological migration. Hence, the near exclusive presence of methane suggests that the hydrocarbon gases found at Site U1320 are of biogenic, not thermogenic, origin.

Concentrations of methane fluctuate with depth. The highest concentration of methane $(57,714$ ppmv) is observed at 122 mbsf. There is a mud layer above $~ 79$ mbsf (lithostratigraphic Unit II) that may play a caprock role, sealing the underlying strata. According to the lithologic description, gas-bearing strata from 79 to 159 mbsf (lithostratigraphic Units II, III, and IV) are mixed associations of sand and mud, which might serve as a natural reservoir for biogenic methane. Below 159 mbsf, methane concentrations decrease to 219 mbsf. The slight increase in methane concentrations observed between 228 and 294 mbsf is similar to the trend observed at Site U1319.

\section{Microbiology}

\section{Biomass enumeration}

Prokaryotic cell enumeration at Site U1320 was conducted using whole-round core samples for microbiology. The sampling frequency for microbiology was every 5-10 m between 2.92 and $92.4 \mathrm{mbsf}$ (nine samples) and every $\sim 20-30 \mathrm{~m}$ between 92.4 and 284.8 mbsf (seven samples). The highest biomass was found in the sample nearest to the seafloor (7.5 mbsf), which contained $1.2 \times 10^{6}$ cells $/ \mathrm{mL}$. Cell numbers sharply decrease with depth without anomalies (Fig. F25; Table T12). The trend of the vertical profile of cell density is normal, but the amount of biomass was low considering the high sedimentation rates at Site U1320.

Methane bubbles were observed in several core samples, perhaps due to biogenic methanogenesis. However, the low biomass suggests low in situ microbial activity at Site U1320, and large anomalous cell numbers in the sediments that could be related to methane production were not observed. This indicates that the biogenic methane found in high concentrations 79 to 159 mbsf (see above) were either generated in the geological past or migrated into their present location.

\section{Physical properties}

Laboratory measurements at Site U1320 were performed to provide downhole profiles of physical properties at a reference site with assumed hydrostatic pore pressure conditions.

\section{Density and porosity}

Porosities at Site U1320 range from $67 \%$ at the top of the hole to $40 \%$ near the bottom. In general, porosity decreases with depth and increasing vertical hydrostatic effective stress $\left(\sigma_{\mathrm{vh}}{ }^{\prime}\right)$ (Fig. F26).

In the uppermost part of the section, mostly in lithostratigraphic Unit II, the porosity versus vertical hydrostatic effective stress profile is jagged (Fig. F26). High variability of porosity in this unit is probably associated with sand and silt in this section. Low porosity at the boundary between lithostratigraphic Units II and III at 137 mbsf correlates well with seismic Reflector R30. Lithostratigraphic Unit III (137.5$145.3 \mathrm{mbsf}$ ) has similar porosities to those of Unit II. From the top of lithostratigraphic Unit IV (145.3174.4 mbsf), where the hydrostatic effective stress exceeds $1 \mathrm{MPa}$, porosity values gradually decrease. In this interval, which consists mostly of clay, porosities decrease $\sim 5 \%$. Nevertheless, a peak is observed near the boundary between lithostratigraphic Units IV and V at 174.4 mbsf that correlates well with seismic Reflector R40.

Gamma ray attenuation (GRA) bulk densities in lithostratigraphic Unit I ( $0-2.65 \mathrm{mbsf})$ increase with depth from 1.33 to $1.4 \mathrm{~g} / \mathrm{cm}^{3}$. In lithostratigraphic Unit II (2.65-137.50 mbsf), densities are higher and vary from 1.5 to $2.1 \mathrm{~g} / \mathrm{cm}^{3}$ (Fig. F27A). These densities depend greatly on the nature of sediments encountered. Poor recovery in lithostratigraphic Subunits IIC (37.76-82 mbsf) and IID (82-124.6 mbsf) make the results more difficult to interpret. However, the trend observed in wireline logging bulk density indicates that the overall pattern of the bulk density curve is preserved both in the moisture and density (MAD) and GRA data. The trend in bulk density mirrors that of porosity. Therefore, lithostratigraphic Unit III shows typically low bulk densities, whereas they are high within lithostratigraphic Unit IV. The boundary between lithostratigraphic Units IV and V 
is marked by a decrease in bulk density. Bulk density values then gradually increase to TD, approximating an exponential trend. Densities are $>2 \mathrm{~g} / \mathrm{cm}^{3}$ at the bottom of the hole.

Grain densities have a more constant profile, oscillating between 2.4 and $2.8 \mathrm{~g} / \mathrm{cm}^{3}$ (average $=2.72 \mathrm{~g} /$ $\mathrm{cm}^{3}$ ) (Fig. F27B). Wood and high organic contentbearing clays between 3.9 and $5 \mathrm{mbsf}$ are associated with grain densities as low as $2.1 \mathrm{~g} / \mathrm{cm}^{3}$. Grain densities within massive sand layers range from 2.65 to $2.75 \mathrm{~g} / \mathrm{cm}^{3}$. Greenish clay has a grain density of $\sim 2.7$ $\mathrm{g} / \mathrm{cm}^{3}$. Grain densities in lithostratigraphic Units III and IV are slightly lower than those of the sediments immediately above and below.

The density profile from wireline logging at Site U1320 is shown in Figure F27A for comparison purposes. In general, the patterns observed in densities measured using the multisensor track (MST), MAD methods, and wireline logging are consistent. However, wireline bulk densities are often higher than those measured by GRA and MAD. GRA and MAD results may reflect gas expansion, unloading ( 5\%), and disturbance from XCB drilling. The intervals lacking MST and MAD data because of poor core recovery are described on the basis of available wireline logging data.

\section{Noncontact resistivity}

Within lithostratigraphic Unit I (0-2.65 mbsf), mainly composed of greenish gray clay, noncontact resistivity (NCR) increases linearly with depth (Fig. F28A). This trend correlates with an increase in GRA bulk densities (Fig. F27A). The general trend in NCR correlates with wireline logging resistivity (deep, medium, and shallow induction resistivity) (Fig. F28B).

Lithostratigraphic Unit III (137.5-145.3 mbsf) consists of mostly clay, which translates to low resistivity values in the logs. High porosities at/near the boundary between Units III and IV (145.3 mbsf) are mimicked by NCR and wireline resistivities. Lithostratigraphic Units IV and V are characterized by relatively constant resistivities $(\sim 1 \Omega \mathrm{m})$, only interrupted by peaks below and above no-recovery intervals near the boundary between Units IV and V (174.4 mbsf). This general trend correlates with wireline resistivity, except between 265 and $285 \mathrm{mbsf}$, where shallow resistivities are slightly lower (probably due to a borehole washout). Wireline resistivities show two significant changes at 180 and $285 \mathrm{mbsf}$ that correlate with seismic Reflectors R40 and R60.

Wireline resistivities vary from 0.2 to $2 \Omega \mathrm{m}$ between 62.5 (top of the logged section) and 176 mbsf (average $=\sim 1.2 \Omega \mathrm{m}$ ) (Fig. F28B). In the same interval, NCR values vary from 0.4 to $1.6 \Omega \mathrm{m}$ (average $=1$
$\Omega m$ ) (which includes values near the edge of no recovery) (Fig. F28A). NCR values are consistently lower than wireline resistivities, possibly due to differences between in situ measurement and laboratory conditions (temperature and pressure), as well as the formation of voids due to gas expansion.

\section{Magnetic susceptibility}

Magnetic susceptibility values in the uppermost part of the log, corresponding to lithostratigraphic Unit I (0-2.65 mbsf), rapidly increase from $17 \times 10^{-5}$ to $50 \times$ $10^{-5}$ SI (Fig. F29). Lithostratigraphic Unit II (2.65137.50 mbsf) can be divided into several subunits based on magnetic susceptibility data that correlate with lithostratigraphic Subunits IIA-IIE (see "Lithostratigraphy"). Despite low recovery in the lower part of lithostratigraphic Unit II (Cores 308-1320A$10 \mathrm{X}$ through $14 \mathrm{X}$ ), high magnetic susceptibility values correlate with the occurrence of sand-rich turbidite sequences. The base of lithostratigraphic Unit II is characterized by a relatively constant magnetic susceptibility value of $\sim 35 \times 10^{-5} \mathrm{SI}$. Magnetic susceptibility values in lithostratigraphic Unit III (137.50$145.30 \mathrm{mbsf}$ ) are similar to those from the base of lithostratigraphic Unit II except at its base, where a peak can be correlated with ash Layer Y8 (see "Lithostratigraphy"). At Site U1319, however, ash Layer Y8 correlates with a local minimum magnetic susceptibility value. Within lithostratigraphic Unit IV (145.30-174.40 mbsf), high magnetic susceptibility values can be correlated with silt/sand layers. Magnetic susceptibilities in lithostratigraphic Unit V (174.40-299.61 mbsf) increase from $40 \times 10^{-5}$ to $90 \times$ $10^{-5}$ SI. This could indicate a downward change in the mineral composition. Lithology alternates between greenish gray, brownish green, and brownish red clays and black organic-rich clays (see "Lithostratigraphy").

\section{Thermal conductivity}

The average thermal conductivity is $1.2 \pm 0.31 \mathrm{~W} /$ $(\mathrm{m} \cdot \mathrm{K})$ (Fig. F30). The upper part of the profile (lithostratigraphic Units I-IV) has high variability in thermal conductivity $(0.8-2.2 \mathrm{~W} /[\mathrm{m} \cdot \mathrm{K}])$. The high frequency of thick sandy-silty layers in these units can provide scattered values, due to higher thermal conductivities in the sand. Values $<1.0 \mathrm{~W} /(\mathrm{m} \cdot \mathrm{K})$ may reflect low-quality measurements caused by core biscuiting. In lithostratigraphic Unit $\mathrm{V}$, thermal conductivity measurements were performed in mud/ clay sediments, as seen in the lithostratigraphic log (see "Lithostratigraphy"). In this part of the log, thermal conductivities increase from 1 to $1.3 \mathrm{~W} /$ $(\mathrm{m} \cdot \mathrm{K})$ and the trend fits an almost linear increase with depth, as expected from the decreasing porosity profile (Fig. F27C). 


\section{$P$-wave velocity}

$P$-wave velocity measurements performed on split sections resulted in acceptable data for the uppermost $20 \mathrm{~m}$ only, probably because of voids and cracks formed by gas expansion (Fig. F27C). Measurements on distilled water were carried out regularly to check that unrealistic negative values were not caused by malfunctioning equipment. Transverse velocities (along the $\mathrm{x}$ - and $\mathrm{y}$-axis) and longitudinal velocities (along the $\mathrm{z}$-axis) using the $P$-wave sensor (PWS) probes produced results for three core sections from 4.18 to $16.71 \mathrm{mbsf}$ (Fig. F27C). Average velocity along the $\mathrm{x}$-axis $=1541.1 \mathrm{~m} / \mathrm{s}$, along the $\mathrm{y}$-axis $=1496 \mathrm{~m} / \mathrm{s}$, and along the $\mathrm{z}$-axis $=1528.3 \mathrm{~m} / \mathrm{s}$. These values are near the velocity of the control measurements in distilled water, indicating high porosities and low consolidation of sediments in these three sections (Fig. F27C).

\section{Shear strength}

Undrained shear strength measured using the automated vane shear (AVS) apparatus consistently matched those measured using the handheld penetrometer (Fig. F31A).

Peak undrained shear strengths increase systematically downhole from near zero within lithostratigraphic Unit I to $\sim 100 \mathrm{kPa}$ at $160 \mathrm{mbsf}$ (Fig. F31A, F31B). Considerable scatter in the data appears below 160 mbsf. As seen in the corresponding measurements at Site U1319, this scatter could partially result from $\mathrm{XCB}$ coring. The $\mathrm{XCB}$ causes biscuiting and local failure planes in the core. The residual shear strength profile has relatively high values in the upper 80 mbsf. From that point onward the residual undrained shear strength profile shows much lower values. No significant variations are observed until 180 mbsf. Then values gradually increase to $\sim 50 \mathrm{kPa}$ in lithostratigraphic Unit V.

The sensitivity (peak/residual shear strength) is low in the intervals from 0 to 110 and 185 to $300 \mathrm{mbsf}$ (Fig. F31C). In the intermediate interval that composes the lower part of lithostratigraphic Units II, III, and the upper part of IV, higher sensitivities are caused by relatively low values of residual shear strength.

Peak undrained shear strengths measured at this site plot within 0.2 and 0.025 ratios with respect to the vertical hydrostatic effective stress (Fig. F32). These ratios are rather low, especially when compared to the values observed in the uppermost sediment column for conventional piston cores.

\section{Summary}

At Site U1320, MST, MAD, and shear strength data show two different types of behavior. The lower part of lithostratigraphic Unit V is similar to the profile recorded at Site U1319. The sequence above has greater variations in bulk density and porosity, which are the result of alternating lithologies encountered at this site (see "Lithostratigraphy"). Overall, Sites U1319 and U1320 show comparable trends in porosity versus vertical hydrostatic effective stress. Clays in lithostratigraphic Unit V (which correspond to those of lithostratigraphic Unit VI at Site U1319) possibly show slightly higher porosities relative to vertical hydrostatic effective stresses. This could suggest that lithostratigraphic Unit V at Site U1320 is slightly underconsolidated.

Undrained shear strength values increase with depth from near $0 \mathrm{kPa}$ at the top of Hole U1320A to almost $200 \mathrm{kPa}$ at the bottom. An interval with relatively constant values of $\sim 100 \mathrm{kPa}$ occurs between 110 and 170 mbsf (lower part of lithostratigraphic Unit II, Unit III, and upper part of Unit IV). This interval also has low residual undrained shear strengths and high sensitivities that coincide with an MTD seen on seismic reflection profiles (see "Lithostratigraphy"). Below this interval, the undrained shear strength profile has a more serrated pattern but increases with depth.

\section{Downhole measurements}

Site U1320 marked the second location drilled during Expedition 308 and the first time that downhole wireline logging operations were conducted. The primary logging objectives in Hole U1320A were to

- Provide in situ measurements of the physical properties,

- Define the lithostratigraphy where core recovery was incomplete, and

- Determine the lithology and facies of turbidites to allow lateral correlation between Sites U1319, U1320, and U1321.

\section{Operations}

\section{Wireline logging}

Following coring operations in Hole U1320A, the hole was conditioned for wireline logging by displacing $96 \mathrm{bbl}$ of $8.9 \mathrm{ppg}$ sepiolite mud, running a wiper trip, and placing the pipe at $62.5 \mathrm{mbsf}$ (1542.9 mbrf). Three tool strings were deployed in the following order:

1. The triple combo tool string consisting of the Hostile Environment Gamma Ray Sonde (HNGS), Accelerator Porosity Sonde (APS), Hostile Environment Litho-Density Sonde (HLDS), and Dual Induction Tool; 
2. The FMS-sonic tool string consisting of the Scintillation Gamma Ray Tool (SGT), Dipole Sonic Imager (DSI), General Purpose Inclinometry Tool, and FMS; and

3. The WST for a check shot survey.

All wireline tool deployments were performed with the wireline heave compensator. Main and repeat passes were recorded with the triple combo and FMSsonic tool strings to a total depth of 299.6 mbsf. Rig floor preparations for wireline logging operations began on 9 June 2005 at $2155 \mathrm{~h}$ and were completed by 10 June at $1730 \mathrm{~h}$.

In the first pass with the triple combo tool string, we encountered an obstruction at 173 mbsf that prevented the tool string from reaching the bottom of the hole. On the second pass, the triple combo tool string was successfully lowered to 299.6 mbsf. HLDS caliper readings of $\sim 43 \mathrm{~cm}$ show washouts between 102 and 103 mbsf and from 167 to 173 mbsf.

The FMS-sonic tool string deployment reached 299.6 mbsf with both main and repeat passes. The lockable float valve (LFV) temporarily obstructed tool string entry into the borehole, but this problem was overcome. During the first pass, data were collected at a logging speed of $275 \mathrm{~m} / \mathrm{h}$ and the DSI was run in $P$ and $S$-wave (P\&S) mode with a sampling rate of 15 $\mathrm{Hz}$ to acquire high-quality compressional wave velocity data. During the second pass, $P \& S$, cross-dipole, and Stoneley modes were recorded at $3 \mathrm{~Hz}$ sampling rate. The LFV was not locked in position at the time of reentering the pipe; therefore, seawater was pumped down the pipe and the tool string was pulled safely into the pipe. The FMS-sonic tool string was retrieved to the rig floor, and rigdown was completed at $1004 \mathrm{~h}$ on 10 June 2005.

The marine mammal watch began by placing observers at the bow and stern of the JOIDES Resolution $1 \mathrm{~h}$ prior to the check shot operations. The WST was rigged up during the initial stages of the marine mammal watch and lowered through the drill pipe at $\sim 1000 \mathrm{~m} / \mathrm{h}$. The LFV obstructed lowering the tool into the borehole, and seawater was pumped to help open the LFV. Approximately 20 min was spent trying to bypass the washout zone at 173 mbsf, after which the tool was successfully run down to 299.6 mbsf. A 30 min "soft shooting start" began during the tool's descent and was completed when the tool reached 299.6 mbsf. Based on the HLDS caliper measurements, 14 stations in $\sim 20 \mathrm{~m}$ intervals were selected for the check shot (Table T13). The GI seismic source had a 45 in 3 generator chamber volume, 105 in $^{3}$ injector chamber volume, and total pressure of 2000 psi. The recording length was $5 \mathrm{~s}$ with a sampling rate of $1 \mathrm{~ms}$ and a $40 \mathrm{~ms}$ delay time. At $1205 \mathrm{~h}$ (local time), a single common bottlenose dolphin was spotted $5 \mathrm{~m}$ off the port stern quarter. The GI source was shut down and the firing circuit secured. Following a 30 min observation period with no further marine mammal sightings, a $30 \mathrm{~min}$ "soft shooting start" began at 500 psi and finished at 2000 psi. The experiment lasted $\sim 3 \mathrm{~h}$ with $\sim 140$ shots being fired.

\section{Log data quality}

The log data were depth-shifted using the FMS-sonic second pass as the reference depth curve with 1478 mbrf as the water depth. Environmental corrections were also made.

Hole diameter was recorded by the hydraulic caliper on the HLDS and by the calipers on the FMS (Fig. F33). HNGS and SGT data were corrected for borehole diameter. APS and HLDS data were corrected for standoff and hole diameter. The caliper data show that the hole diameter in the interval between 176 and 296 mbsf, which corresponds to lithostratigraphic Unit V, was relatively uniform $(\sim 25 \mathrm{~cm})$. Enlarged borehole intervals $>30 \mathrm{~cm}$ were observed at 100,110 , and 170 mbsf. These zones correspond to alternating sand and silt/clay layers identified in lithostratigraphic Units I-IV.

\section{Results}

\section{Gamma radiation}

SGT and HNGS gamma ray measurements are in good agreement to 211 mbsf. Gamma ray data display large variations in the upper part of the borehole (65-176 mbsf), ranging from 10 to 110 gAPI (Fig. F33). Low gamma ray values ( $<60$ gAPI) can be correlated to sand-prone layers in core samples, whereas clay layers display higher values (>70 gAPI). However, low gamma ray values observed in lithostratigraphic Unit III may be related to the high abundance of calcareous foraminifers and microfossils usually characterized by low radiogenic element concentration. The spectral measurements, consisting of contributions from the radioactive decay of ${ }^{40} \mathrm{~K},{ }^{232} \mathrm{Th}$, and ${ }^{238} \mathrm{U}$ isotopes, show that the decay of ${ }^{232} \mathrm{Th}$ is the main gamma ray contributor (Fig. F33). ${ }^{232} \mathrm{Th}$ is commonly transported to depositional environments as clay fraction showing an affinity to terrestrial clay minerals. The range of ${ }^{232} \mathrm{Th}$ values measured in Hole U1320A fall within values reported for illite and smectite (Rider, 1996). Clays observed in core samples support this interpretation (see "Lithostratigraphy").

\section{Resistivity}

Deep-, medium-, and shallow-induction resistivity data from Hole U1320A show similar values except 
between 265 and 285 mbsf, where the shallow resistivity is slightly lower (Fig. F33). The lower shallow resistivity could be an indication of fluid invasion into a more permeable layer. Resistivity varies from 0.2 to $2 \mathrm{~m}$ between the top of the logged section and 176 mbsf. Low resistivity values $(<0.7 \mathrm{~m})$ recorded at $70,76,110$, and $176 \mathrm{mbsf}$ correspond to low gamma ray values and borehole washouts. The interval below 176 mbsf displays minimal variations in electrical resistivity, with the exception of changes at 180 and 285 mbsf, which correlate with seismic Reflectors R40 and R60. Preliminary correlations with the Hole U1320A lithostratigraphy shows that sand intervals have resistivity lower than $\sim 0.7 \mathrm{~m}$.

\section{Density}

Bulk density data were recorded in high-resolution mode. Enlarged borehole conditions degrade measurement quality; therefore, density data where caliper readings are $>40 \mathrm{~cm}$ are low and unreliable. The bulk density logs display large variations between 65 and 176 mbsf, similar to the gamma ray data, with values ranging from 1.1 to $2.3 \mathrm{~g} / \mathrm{cm}^{3}$ and prominent anomalies at 80, 110, 140, and 170 mbsf (Fig. F34). From 176 to 299.6 mbsf density is characterized by a systematic increase from 1.75 to $2.2 \mathrm{~g} / \mathrm{cm}^{3}$. This increase is only interrupted by a sand-rich layer at 230 mbsf, where the density decreases to $1.8 \mathrm{~g} / \mathrm{cm}^{3}$.

\section{Neutron porosity}

Neutron porosity data were recorded in high-resolution mode. Porosity data estimated from core data were compared to neutron porosity data (Fig. F34). Neutron porosity is inconsistent in the upper borehole section, varying from $42 \%$ to $>70 \%$ (Fig. F34). High neutron porosity correlates with low density and compressional velocity, indicating possible washout zones. However, high porosity values may also reflect (1) fracture porosity that is not reflected in moisture and density measurements, which are measured on intact samples, or (2) hydrogen bound in minerals such as clays or in hydrocarbons, which contribute to the measurement; therefore, the raw neutron porosity values are often overestimates.

\section{Formation MicroScanner imaging}

Preliminary shipboard processing provided static and dynamic normalized FMS images (see "Downhole measurements" in the "Methods" chapter). FMS images (Fig. F35) show evidence for slump surfaces, high-angle faulting, and lithologic changes. The resistivity contrast between the sand and clay sediments compares well with the other log data. Where caliper values are high, FMS images are not reliable. Preliminary analyses of the FMS images show that in many intervals the borehole is irregular, resulting in an uneven contact of the FMS pads with the borehole wall. Nevertheless, some good-quality images provide information that could not be gleaned from the cores, particularly where sedimentary and structural features were severely disturbed by the extended core barrel (XCB) coring process (see "Lithostratigraphy;" Fig. F4).

\section{Discussion}

Hole U1320A wireline logs were separated into two zones on the basis of changes in velocity, resistivity, bulk density, and porosity. These zones correspond to major lithology changes identified in cores. Gamma ray data indicate interbedded sand, silt, and clay in the upper section of the borehole, which correlate with lithostratigraphic Units I, II, III, and IV. These units represent muddy and sandy turbidites to $\sim 180$ mbsf, roughly equivalent to the position of seismic Reflector R40 (Fig. F33).

In general, sand-dominated layers have gamma radiation $<60$ gAPI and resistivity $<1.1 \Omega \mathrm{m}$, whereas layers dominated by clay have higher values. Alternating units measured with downhole logs can be correlated to seismic Reflectors R20, R30, and R40. A clear separation of thin-bedded intervals based on the measurements alone is difficult because of the limited vertical resolution of the logging tools. Nevertheless, within intervals of poor core recovery (70120 and $170-190 \mathrm{mbsf}$ ), the log data provide an excellent means to infer lithology and define a nearly complete stratigraphic section for Site U1320. The largest variations in physical properties for the shallow section are observed in density $\left(1.1-2.05 \mathrm{~g} / \mathrm{cm}^{3}\right)$ and neutron porosity (40\%-70\%). Washout zones $\sim 3$ $\mathrm{m}$ thick were encountered at 110 and $170 \mathrm{mbsf}$. These intervals are interpreted as sand-rich layers characterized by increased neutron porosity and caliper readings $(\sim 38 \mathrm{~cm})$ and low density, gamma ray, resistivity, and sonic velocity values. The foraminifer-bearing clay, lithostratigraphic Unit III, has increased resistivity $(>1.4 \Omega \mathrm{m})$, bulk density $(\sim 1.9 \mathrm{~g} /$ $\left.\mathrm{cm}^{3}\right)$, and velocity $(\sim 1.65 \mathrm{~km} / \mathrm{s})$ (Fig. F36), which correlates to seismic Reflector R30. This unit also contains the $84 \mathrm{ka}$ ash Layer Y8, which could not be distinguished in the wireline data. Below $~ 180 \mathrm{mbsf}$, porosity decreases systematically because of sediment compaction.

Data from 299.6 to 170 mbsf are homogeneous and correlate to lithostratigraphic Unit V. This highly bioturbated unit is characterized by mud, clays, the absence of sand layers, and an overall homogeneous lithology (see "Lithostratigraphy"). Density and velocity data display a systematic increase downhole $\left(1.7-2.1 \mathrm{~g} / \mathrm{cm}^{3}\right.$ and $\left.1.5-1.8 \mathrm{~km} / \mathrm{s}\right)$, interrupted at 
230 mbsf, near the projected depth of seismic Reflector R50. Below seismic Reflector R50, bulk density and sonic velocity values increase downhole but on a separate trend from the upper part of lithostratigraphic Unit V (Fig. F34). There are no obvious changes in lithology across this interval, despite the decrease in bulk density and sonic velocity. However, the section below seismic Reflector R50 shows a noticeable increase in methane content (see "Geochemistry and microbiology"). The change near seismic Reflector R50 may be related to a change in the compaction trend.

\section{Logging while drilling and measurement while drilling}

\section{Operations}

Hole U1320B was the first LWD/MWD hole drilled during Expedition 308. Operations began with the initial makeup of the BHA, tool initialization, and calibration. The LWD tools $(17.15 \mathrm{~cm}$ collars $)$ included the GVR tool with a $23.18 \mathrm{~cm}$ button sleeve, MWD (PowerPulse) tool, Array Resistivity Compensated tool, and Vision Density Neutron (VDN) tool. Memory and battery life allowed for $\sim 40 \mathrm{~h}$ of drilling without circulation; when circulating above 375 gpm, battery power was not used. Hole U1320B was spudded at 1479 mbrf with an initial pump rate of $125 \mathrm{gpm}$ and bit rotation of $10 \mathrm{rpm}$. Below 1510 mbrf (31 mbsf) drilling proceeded with a flow rate of $300 \mathrm{gpm}$ and bit rotation of $45 \mathrm{rpm}$. The mud pulsing system began transmitting data after achieving 395 gpm between 1510 and 1528 mbrf (31-49 mbsf). Total depth (320 mbsf) was reached with an average ROP of $\sim 25 \mathrm{~m} / \mathrm{h}$. Real-time data were transmitted to the surface at a rate of $24 \mathrm{~Hz}$ for 13 drilling hours. Hole U1320B was drilled $20 \mathrm{~m}$ deeper than Hole U1320A to ensure that all LWD/MWD sensors recorded measurements to the total depth of Hole U1320A.

\section{Logging data quality}

Figure F37 shows the quality control logs for the Hole U1320B LWD data. The target ROP of $25 \mathrm{~m} / \mathrm{h}$ $( \pm 5 \mathrm{~m} / \mathrm{h})$ was generally achieved except in the upper $8 \mathrm{~m}$ of the hole, where a rapid jet-in was necessary to start the hole. Density caliper log values range between $42 \mathrm{~cm}$ at the top of Hole U1320B where sediments were unconsolidated to $25 \mathrm{~cm}$ near the bottom of the hole where the sediments were more compacted. Several washouts were observed from 0 to $108 \mathrm{mbsf}$, where the caliper readings were $>42 \mathrm{~cm}$. The bulk density correction varies from -0.06 to 0.2 $\mathrm{g} / \mathrm{cm}^{3}$ (mean $\left.=0.06 \mathrm{~g} / \mathrm{cm}^{3}\right)$ (Fig. F37), which indicated good quality bulk density measurements.
The depth (mbsf) for the LWD logs were calculated by identifying the gamma ray signal associated with the seafloor and shifting the logging data to that seafloor reference. For Hole U1320B, it was determined that the gamma ray log pick for the seafloor was at a depth of 1481 mbrf, which was $2 \mathrm{~m}$ deeper than the drillers' depth. The rig floor logging datum was located $10.4 \mathrm{~m}$ above sea level for this hole.

\section{Annular pressure while drilling and equivalent circulating density}

Pressure within the borehole was monitored during MWD operations (see discussion in "Downhole measurements" in the "Methods" chapter) as APWD, APWD excess of hydrostatic (APWD*), and equivalent circulating density referenced to the seafloor $\left(E C_{\text {rsf }}\right)$. APWD* increases slightly with depth. There are several excursions that correspond to low gamma ray values (interpreted as sand intervals) where the density-derived caliper measured enlarged borehole dimensions (Fig. F38). We interpret that sediment loading within the annulus caused these localized increases, which returned to normal conditions after the interval was drilled. Below $100 \mathrm{mbsf}$, both the $\mathrm{ECD}_{\text {rsf }}$ and $\mathrm{APWD}^{*}$ curves show uniform profiles with minor anomalies at $\sim 143,165,209$, and 270 mbsf (Fig. F38). The largest anomalies were 0.88 ppg and $0.23 \mathrm{MPa}$ increases in the $\mathrm{ECD}_{\text {rsf }}$ and $\mathrm{APWD}^{*}$ curves.

\section{Interpretation}

Hole quality in the upper 100 mbsf is highly variable with several caliper measurements $\geq 42 \mathrm{~cm}$. Deeper than $100 \mathrm{mbsf}$, the caliper measured an average diameter of $26.4 \mathrm{~cm}$. The GVR gamma ray log is also highly variable from 0 to 110 mbsf; below this depth gamma radiation is nearly constant ( $74 \mathrm{gAPI})$ with only a $10 \mathrm{~m}$ interval ( 165-175 mbsf) measuring a low value of 15.8 gAPI. From the gamma ray log, we interpret a series of sand and clay interlayers dominating the stratigraphy above $\sim 110$ mbsf. The interval from 165 to 175 mbsf reflects a sand interval that correlates with high caliper reading and seismic Reflector R40. GVR deep button resistivity increases from 0.3 to $2.8 \mathrm{~m}$ from the seafloor to $316 \mathrm{mbsf}$. The variations in resistivity are interpreted as variations in sand and clay content within units of variable thicknesses, especially above 110 mbsf and at 165 mbsf.

The VDN bulk density log increases from $1.0 \mathrm{~g} / \mathrm{cm}^{3}$ at shallow depths to $2.1 \mathrm{~g} / \mathrm{cm}^{3}$ near the bottom of the hole. Below 110 mbsf these data are consistent with variations in core MAD measurements (Fig. F39). Porosity decreases from $95 \%$ to $43 \%$; these val- 
ues are generally higher than those obtained from MAD measurements on core samples (Fig. F39), most likely due to hydrogen bound in clays that contributes to an overestimate in the logging measurement. These trends in the lower part of the hole record compaction where pore volume and water content are decreasing with depth because vertical effective stress is increasing. The density and porosity values in the shallower section reflect the presence of sand units and an enlarged borehole. The PEF log from Hole U1320B follows similar trends as those observed in the gamma ray, resistivity, and density. The PEF log shows a systematic increase from $~ 110$ mbsf followed by a similar gradual decrease before reaching 165 mbsf. These variations are interpreted as gradual changes in clay/sand content (Fig. F39).

GVR resistivity images show thin sand beds within lithostratigraphic Subunit IIE and a sharp contact with the top of lithostratigraphic Unit III that correlates to seismic Reflector R30 (Fig. F40). In addition, these images show steeply dipping beds within clayrich lithostratigraphic Unit V (Fig. F41). Borehole breakouts have also been identified within lithostratigraphic Unit V (Fig. F42). Most of the steeply dipping beds have a north-south orientation, whereas the borehole breakouts have an east-west orientation suggesting a north-south maximum stress direction and deformation.

\section{Core-log-seismic integration}

\section{Core-log-seismic interpretation}

Compressional velocity was measured both with the DSI log and with the WST (check shot). DSI compressional velocities from the top of the logged section to $299.6 \mathrm{mbsf}$ range from 1.53 to $1.82 \mathrm{~km} / \mathrm{s}$ (Fig. F36). Between 70 and 176 mbsf, compressional velocities are more variable.

The lowest velocities are at 110 and 176 mbsf and correspond to borehole washouts (Fig. F37). Seismic surfaces R20, R30, R40, R50, and R60 correspond to contrasts in velocity and density.

In addition to the wireline sonic data, a check shot was completed (Figs. F36, F43; Table T13). The check shot velocities are compared with the predrill timedepth prediction (see Equation 1 in "Background and objectives" in the "Site U1319" chapter) in Figure F43. Between 80 and 200 mbsf the check shot velocities are slightly larger than the velocities predicted prior to drilling.

Wireline and LWD data correlate well (Fig. F44). The largest variations in $\log$ responses occur from the seafloor to $\sim 110$ mbsf, which corresponds to lithostratigraphic Units I and II. These units consist of intercalated layers of clay and sand separated by bio- turbated muddy intervals ranging between 1 and 10 $\mathrm{m}$ in thickness (see "Lithostratigraphy"). These variations are clearly defined in the LWD data. Seismic Reflectors R10-R40 correlate with low density, resistivity, gamma ray, and sonic velocity values, suggesting that these intervals represent transitions from mud-rich layers to sand-prone layers.

LWD and wireline observations are linked to seismic data through a time-depth conversion using check shot data from Hole U1320A. We used LWD density data and the wireline sonic log to construct reflection coefficients for Hole U1320B (Fig. F45). A velocity of $1600 \mathrm{~m} / \mathrm{s}$ was assumed from 0 to $50 \mathrm{mbsf}$. A $200 \mathrm{~Hz}$ minimum-phase Ricker wavelet was convolved with the reflection coefficients to create the synthetic seismogram. The successful correlation of events between the synthetic seismogram and the high-resolution seismic data is achieved from 0 to 140 mbsf; below 140 mbsf no reliable tie is established. Based on the time-depth model, six regional reflections (SF and seismic Reflectors R10, R30, R40, R50, and R60) mapped on high-resolution seismic data have been correlated with logging data from Holes U1320A and U1320B.

\section{Temperature and pressure measurements}

\section{Temperature/dual pressure probe}

Two deployments of the T2P probe were completed in Hole 1320A (Table T14). The first deployment occurred at 126.3 mbsf (below Core 308-U1320A-15X) and the second at 213.0 mbsf (below Core 308U1320A-24X). Both deployments used the tapered needle probe (Fig. F10 in the "Methods" chapter).

\section{T2P Deployment 3}

T2P Deployment 3 used the tapered needle probe. The tapered shaft is stronger than the straight shaft used in T2P Deployment 2 (Hole U1319A; 80.5 mbsf). A drill bit elevation of $1 \mathrm{~m}$ off hole bottom was employed when loading the colleted delivery system in the BHA. This was $11 \mathrm{~m}$ less standoff than that of T2P Deployment 2. It was hoped that a smaller drill bit standoff would aid vertical penetration of the probe into the formation and minimize bending of the needle probe. Details of the deployment are summarized in Table T15.

The $\mathrm{T} 2 \mathrm{P}$ recorded temperature and pressure at the tip; however, the shaft transducer did not record any data during the deployment (Fig. F46). The tip pressure increased during penetration into the sediment and a sharp pressure decrease occurred when the drill string was picked up. Pressure then dissipated until the probe was removed from the sediment. The pressure prior to pulling the tip was $14.24 \mathrm{MPa}$, 
which is significantly less than the hydrostatic pressure $(16.04 \mathrm{MPa})$. Temperature recorded exhibits frictional heating during penetration into the formation when the drill bit was backed off and when the probe was pulled from the formation (Fig. F46). Heating when the drill bit was backed off may indicate that the probe was slightly pulled out of the sediment; this could create subhydrostatic pressure at the tip. The end temperature measurement was $7.23^{\circ} \mathrm{C}$. We interpret this to be the equilibrium temperature in the sediment.

\section{T2P Deployment 4}

T2P Deployment 4 procedures were similar to those of Deployment 3 except we did not use the drill string to push the T2P into the formation. We relied on the weight of the tool string to push the tool into the formation. The deployment was completed after Core 308-U1320A-24X. Table T16 provides an event $\log$ for the deployment.

Pressure was recorded at the tip and the shaft sensors throughout the deployment, and temperature was measured at the tip (Fig. F47). The tip pressure and temperature records increased during penetration into the formation and then dissipated. The final pressure recorded, $18.43 \mathrm{MPa}$, slightly exceeds hydrostatic $(18.32 \mathrm{MPa})$. The final temperature recorded was $9.04^{\circ} \mathrm{C}$. Shaft pressure did not increase during penetration into the sediment. One possible explanation for this was insufficient penetration of the shaft into the sediment. If the sediment stiffness was high, it may have prevented significant penetration of the tool by its own self-weight. To ensure penetration, future deployments were completed with the drill string pushing the probe into the sediment.

\section{Davis-Villinger Temperature-Pressure Probe}

The DVTPP was deployed immediately after Cores 308-1320A-23X (203.4 mbsf) and 32X (289.9 mbsf) (Table T14). Each deployment followed the standard DVTPP deployment procedure (see "Davis-Villinger Temperature-Pressure Probe" in "Downhole measurements" in the "Methods" chapter) to achieve 1 $m$ of penetration into the sediment.

The DVTPP deployments had similar pressure and temperature responses: (1) pressure and temperature increased penetration into the formation, (2) pressure dissipation curves were subhydrostatic, and (3) in situ temperature was measured successfully. At $203.4 \mathrm{mbsf}$, the pressure at the end of the deployment was $1 \mathrm{MPa}$ less than hydrostatic (Fig. F48), whereas at 289.9 mbsf the end-pressure was $\sim 2.5$ MPa less than hydrostatic (Fig. F49). We interpreted these low pressures as caused by an internal leak in the probe. We reassembled the DVTPP to troubleshoot leaks. Equilibrium temperatures $\left(10.20^{\circ} \mathrm{C}\right.$ at $203.4 \mathrm{mbsf}$ and $11.04^{\circ} \mathrm{C}$ at $289.9 \mathrm{mbsf}$ ) are based on the last formation reading. Each of the temperature decay curves were of good quality.

\section{Summary}

Logging operations at Site U1320 provided crucial information about the character and physical properties of the sediments. Core-log integration provided a detailed picture of the bedding style and lithofacies at this site and yielded the following insights:

- Hole U1320A wireline logs can be separated into two intervals on the basis of changes in velocity, resistivity, bulk density, and porosity. These intervals correspond to the major lithology changes identified in the cores. Gamma ray data indicate intercalated layers of sand, silt, and clay in the upper section of the borehole, which were defined as lithostratigraphic Units I, II, III, and IV. These units represent muddy and sandy mass transport deposits (turbidites) to a depth of $\sim 180$ mbsf, roughly equivalent to seismic Reflector R40.

- In intervals of poor core recovery (70-120 and 170-190 mbsf), log data constrain lithology and define a nearly complete stratigraphic section for Site U1320.

- Data retrieved from 180 mbsf to 299.6 mbsf are homogeneous and correlate to lithostratigraphic Unit V. In this unit, porosity decreases systematically, which suggests sediment compaction. It was possible to relate seismic Reflector R50 to the density and velocity data despite no obvious changes in lithology across this interval.

- The wireline sonic log and check shot survey provided complementary measures of velocity. A synthetic seismogram for Hole U1320A was constructed using wireline velocity and LWD density data. The correlation between the synthetic seismogram and the high-resolution seismic data is good in the shallow section and allows a qualitative correlation between several seismic reflections with observations in core and logging data in the deeper section.

- LWD/MWD data from Hole U1320B supplements the intervals not covered by the wireline measurements. GVR resistivity images allow identification of thin sand beds within the upper $110 \mathrm{mbsf}$ and steeply dipping beds within clay-rich lithostratigraphic Unit V. East-west-orientated borehole breakouts within lithostratigraphic Unit V suggest a north-south-oriented maximum stress direction. 


\section{References}

Badalini, G., Kneller, B., and Winker, C.D., 2000. Architecture and processes in the late Pleistocene Brazos-Trinity turbidite system, Gulf of Mexico continental slope. Deep-Water Reservoirs of the World: Proc. GCSSEPM 20th Annu. Res. Conf., 16-34.

Baker, P.A., and Burns, S.J., 1985. The occurrence and formation of dolomite in organic-rich continental margin sediments. AAPG Bull., 69:1917-1930.

Bassinot, F.C., Labeyrie, L.D., Vincent, E., Quidelleur, X., Shackleton, N.J., and Lancelot, Y., 1994. The astronomical theory of climate and the age of the Brunhes-Matuyama magnetic reversal. Earth Planet. Sci. Lett., 126:91108. doi:10.1016/0012-821X(94)90244-5

Beaubouef, R.T., Abreu, V., and Van Wagoner, J.C., 2003. Basin 4 of the Brazos-Trinity slope system, western Gulf of Mexico: the terminal portion of a late Pleistocene lowstand system tract. In Roberts, H.H., Rosen, N.C., Fillon, R.H., and Anderson, J.B. (Eds.), Shelf Margin Deltas and Linked Downslope Petroleum Systems: Global Significance and Future Exploration Potential: Proc. 23 Ann. Res. Conf., GCSSEPM Found., 45-66.

Beaubouef, R.T., and Friedmann, S.J., 2000. High resolution seismic/sequence stratigraphic framework for the evolution of Pleistocene intra slope basins, western Gulf of Mexico: depositional models and reservoir analogs. Deep-Water Reservoirs of the World: Proc. GCSSEPM 20th Annu. Res. Conf., 40-60.

Berggren, W.A., Hilgen, F.J., Langereis, C.G., Kent, D.V., Obradovich, J.D., Raffi, I., Raymo, M.E., and Shackleton, N.J., 1995. Late Neogene chronology: new perspectives in high-resolution stratigraphy. Geol. Soc. Am. Bull., 107:1272-1287. doi:10.1130/00167606(1995)107<1272:LNCNPI>2.3.CO;2

Cisowski, S.M., and Hall, F.R., 1997. An examination of the paleointensity record and geomagnetic excursions recorded in Leg 155 cores. In Flood, R.D., Piper, D.J.W., Klaus, A., and Peterson, L.C. (Eds.), Proc. ODP, Sci. Results, 155: College Station, TX (Ocean Drilling Program), 231-243.

Drexler, J.W., Rose, W.I., Jr., Sparks, R.S.J., and Ledbetter, M.T., 1980. The Los Chocoyos ash, Guatemala: a major stratigraphic marker in middle America and three ocean basins. Quat. Res., 13:327-345. doi:10.1016/00335894(80)90061-7

Flood, R.D., Piper, D.J.W., Klaus, A., et al., Proc. ODP, Init. Repts., 155: College Station, TX (Ocean Drilling Program).

Freed, W.K., and Healy, N., 1974. Excursions of the Pleistocene geomagnetic field recorded in Gulf of Mexico sediments. Earth Planet. Sci. Lett., 24:99-104. doi:10.1016/0012-821X(74)90013-2

Gieskes, J.M., 1983. The chemistry of interstitial waters of deep-sea sediments: interpretation of deep-sea drilling data. In Riley, J.P., and Chester, R. (Eds.), Chemical Oceanography (Vol. 8): London (Academic), 221-269.

Hine, N., and Weaver, P.P.E., 1998. Quaternary. In Bown P.R. (Ed), Calcareous Nannofossil Biostratigraphy: Dordrecht (Kluwer Academic Publishers), 266-283.

Kvenvolden, K.A., and Barnard, L.A., 1983. Gas hydrates of the Blake Outer Ridge, Site 533, Deep Sea Drilling Project Leg 76. In Sheridan, R.E., Gradstein, F.M., et al., Init. Repts. DSDP, 76: Washington (U.S. Govt. Printing Office), 353-365.

Mallarino, G., Drexler, A.W., Beaubouef, R.T., Abreu, V., and Labeyre, L., in press. Sea level influence on the nature and timing of a mini-basin sedimentary fill (northwestern slope of the Gulf of Mexico). AAPG Bull.

Rider, M.H., 1996. The Geological Interpretation of Well Logs (2nd ed.): Caithness (Whittles Publishing).

Stupavsky, M., and Gravenor, C.P., 1984. Paleomagnetic dating of Quaternary sediments: a review. In Mahaney, W.C. (Ed.), Quaternary Dating Methods: Amsterdam (Elsevier).

Winker, C.D., 1996. High-resolution seismic stratigraphy of a late Pleistocene submarine fan ponded by salt-withdrawal minibasins on the Gulf of Mexico continental slope. Proc. 3rd Annu. Offshore Technol. Conf., 28(1):619628.

Winker, C.D., and Booth, J.R., 2000. Sedimentary dynamics of the salt-dominated continental slope, Gulf of Mexico: integration of observations from the seafloor, near-surface, and deep subsurface. Deep-Water Reservoirs of the World: Proc. GCSSEPM 20th Annu. Res. Conf., 10591086.

Publication: 8 July 2006

MS 308-104 
Figure F1. Reflection seismic section of dip Line 3020 in the immediate vicinity of Site U1320, showing positions of seismic Reflectors R10 through R60 and the seafloor reflector (SF). Surfaces also delineated in Table T1 in the "Site U1319" chapter.

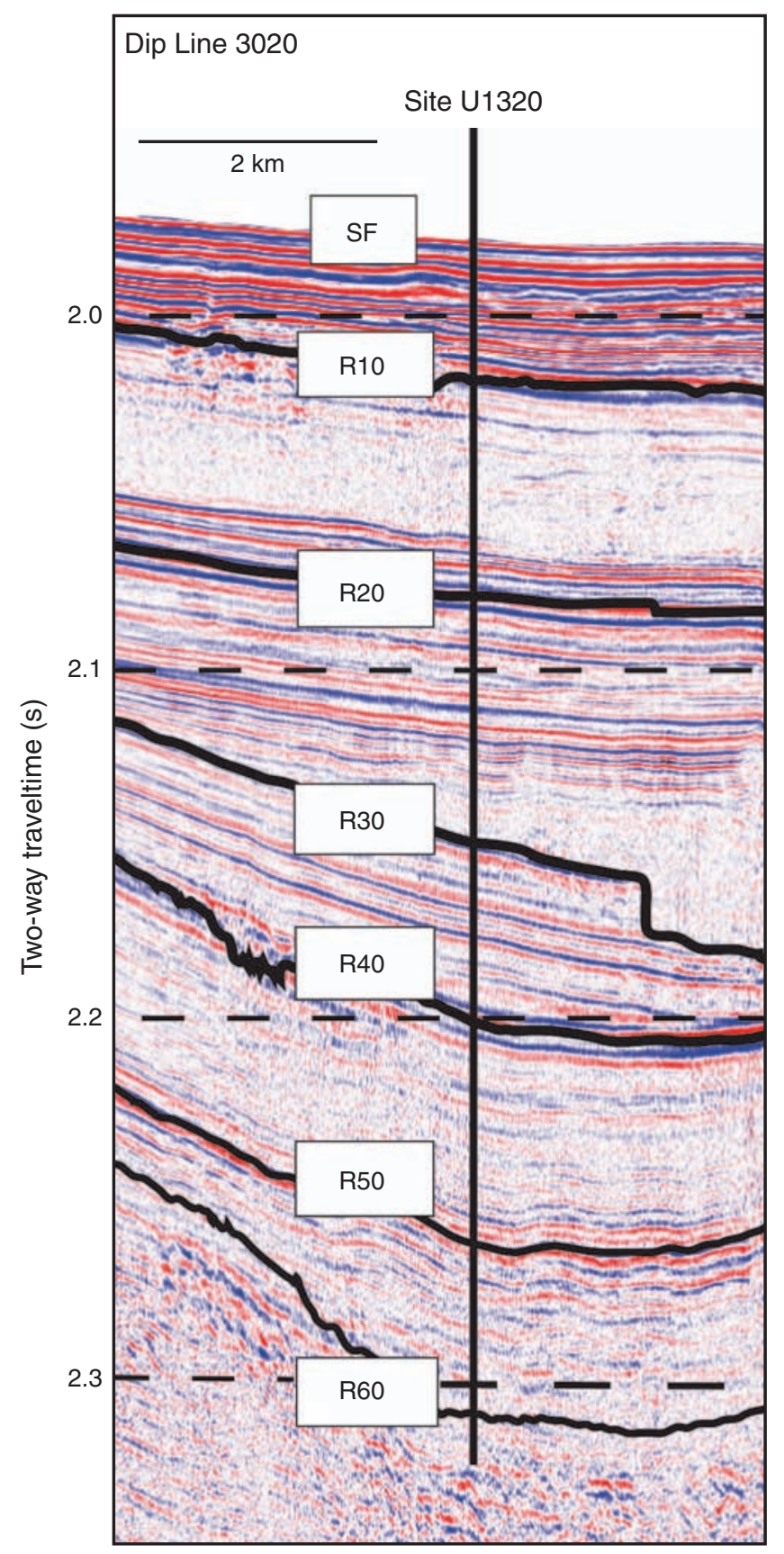


Figure F2. Lithostratigraphic summary. Core recovery (black = recovered, white $=$ missing, red $=$ overlapping due to core expansion), key seismic reflectors, Formation MicroScanner (FMS) and resistivity-at-the-bit (RAB) gamma ray (GR) logs. A slight depth shift was applied to the FMS data to match the unshifted RAB GR log. Colors and width of boxes indicate lithology and grain size, respectively. Clear boxes represent inferred lithology from MWD/LWD gamma ray logs. Bends at the top of sand package symbols represent fining upward. Differences between the cored hole (U1320A) and the logged hole (U1320B) are shown in the middle of the diagram, where local erosion is interpreted to explain the differences in log character.

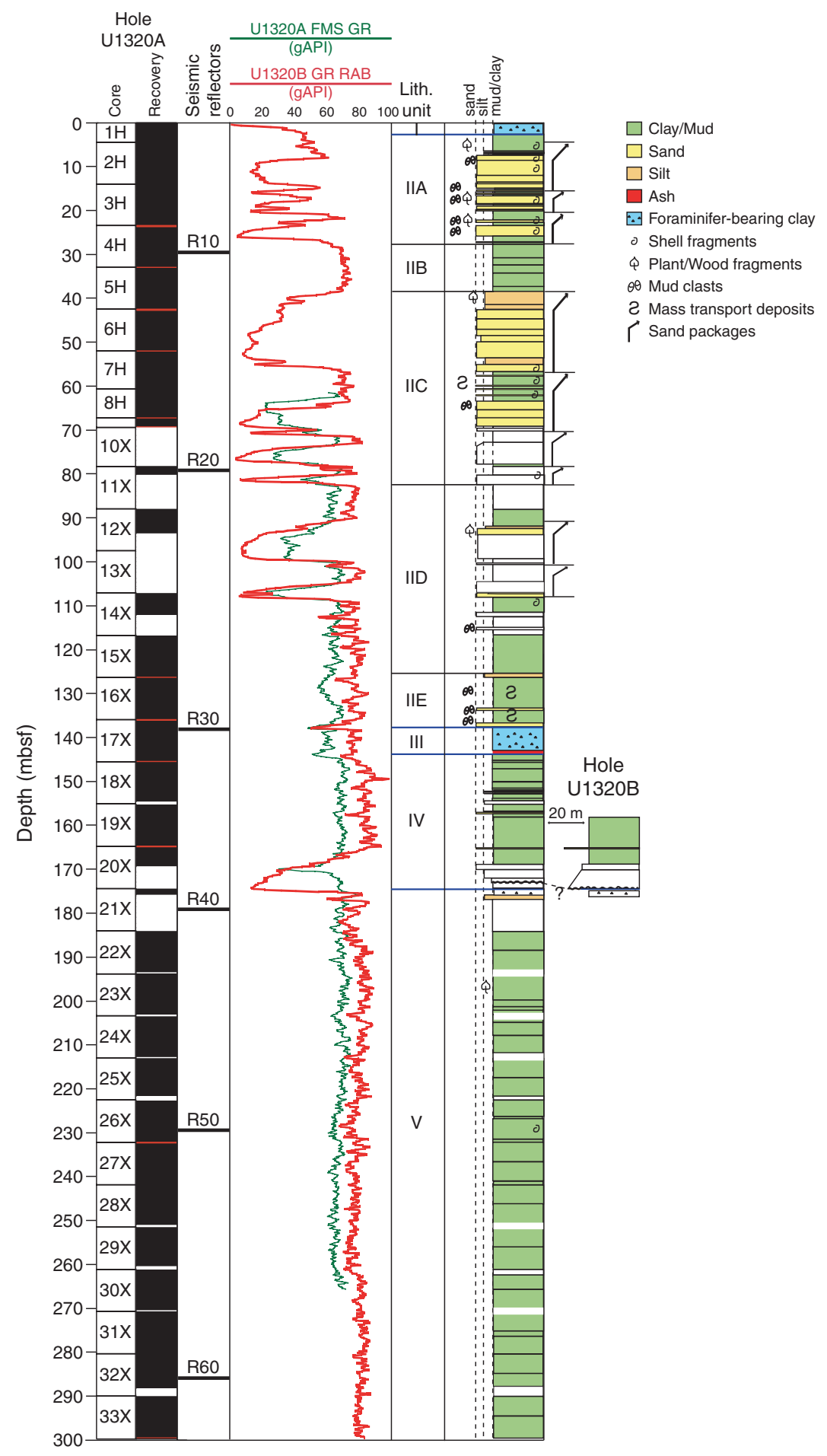


Figure F3. Lithostratigraphic Subunits IIA-IIE. A. Mud with organic-rich fine-sand laminae at 34-35 and 46$50 \mathrm{~cm}$ (interval 308-U1320A-2H-1, 28-58 cm). B. Massive fine upper sand (interval 308-U1320A-3H-3, 0-32 $\mathrm{cm}$ ). C. Mud with fine-sand laminae at 46, 48, 50, 61-62, 63-64, 68, 69, 71, and $75.5 \mathrm{~cm}$ (interval 308U1320A-3H-5, 45-75 cm). D. Sharp contact at $93 \mathrm{~cm}$ of massive fine upper sand above mud at the base of Subunit IIA (interval 308-U1320A-4H-2, 73-107 cm). (Continued on next page.)

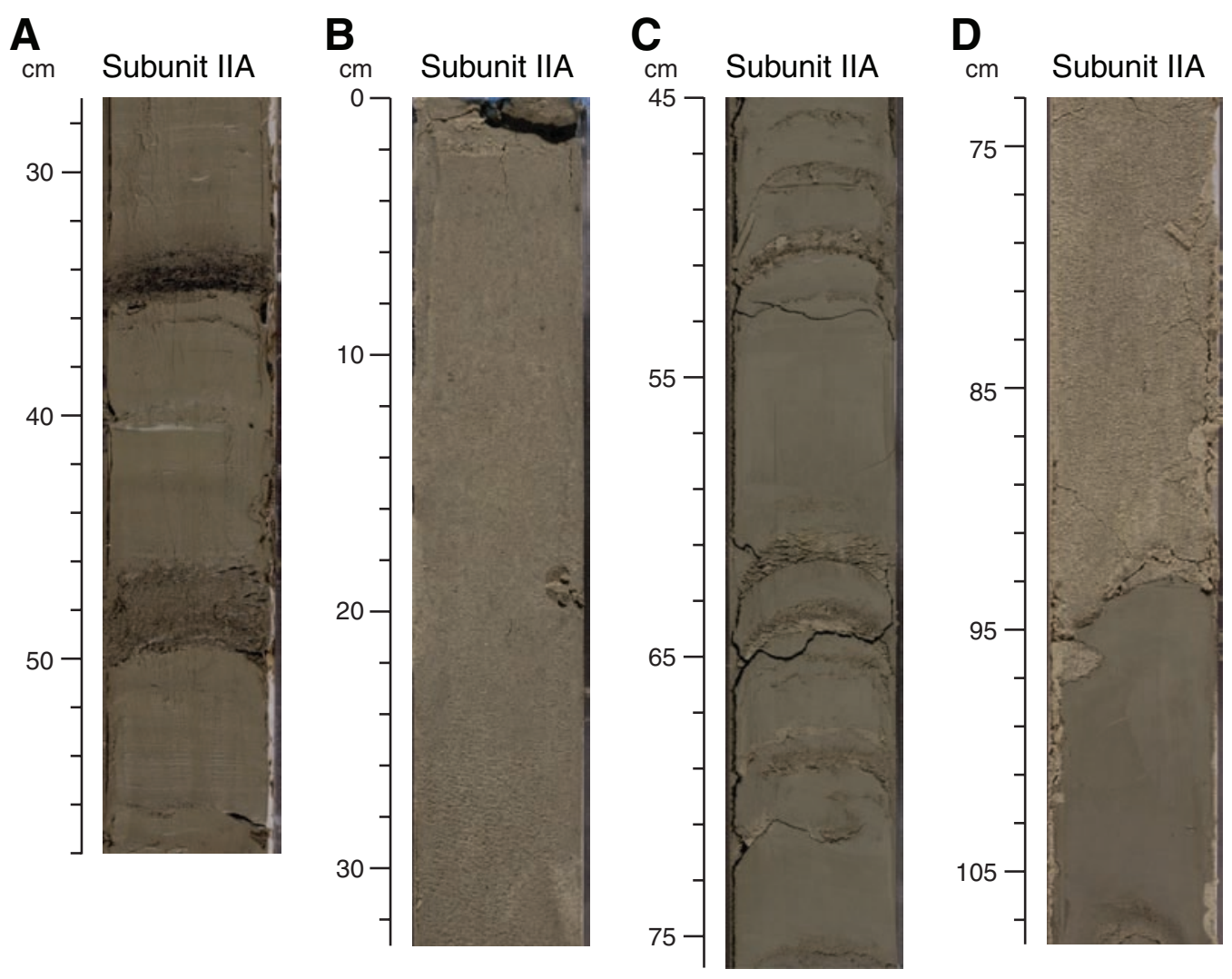


Figure F3 (continued). E. Possible burrows in clay (interval 308-U1320A-4H-5, 20-56 cm. F. Massive fine upper sand (interval 308-U1320A-9H-1, 0-20 cm). G. Very fine sand with plant fragments and wood (interval 308-U1320A-12X-4, 5-40 cm). H. Debris flow with mud clasts (interval 308-U1320A-15X-5, 60-94 cm). I. Clay with fine sand laminae and mud clasts (interval 308-U1320A-16X-5, 108-142 cm).
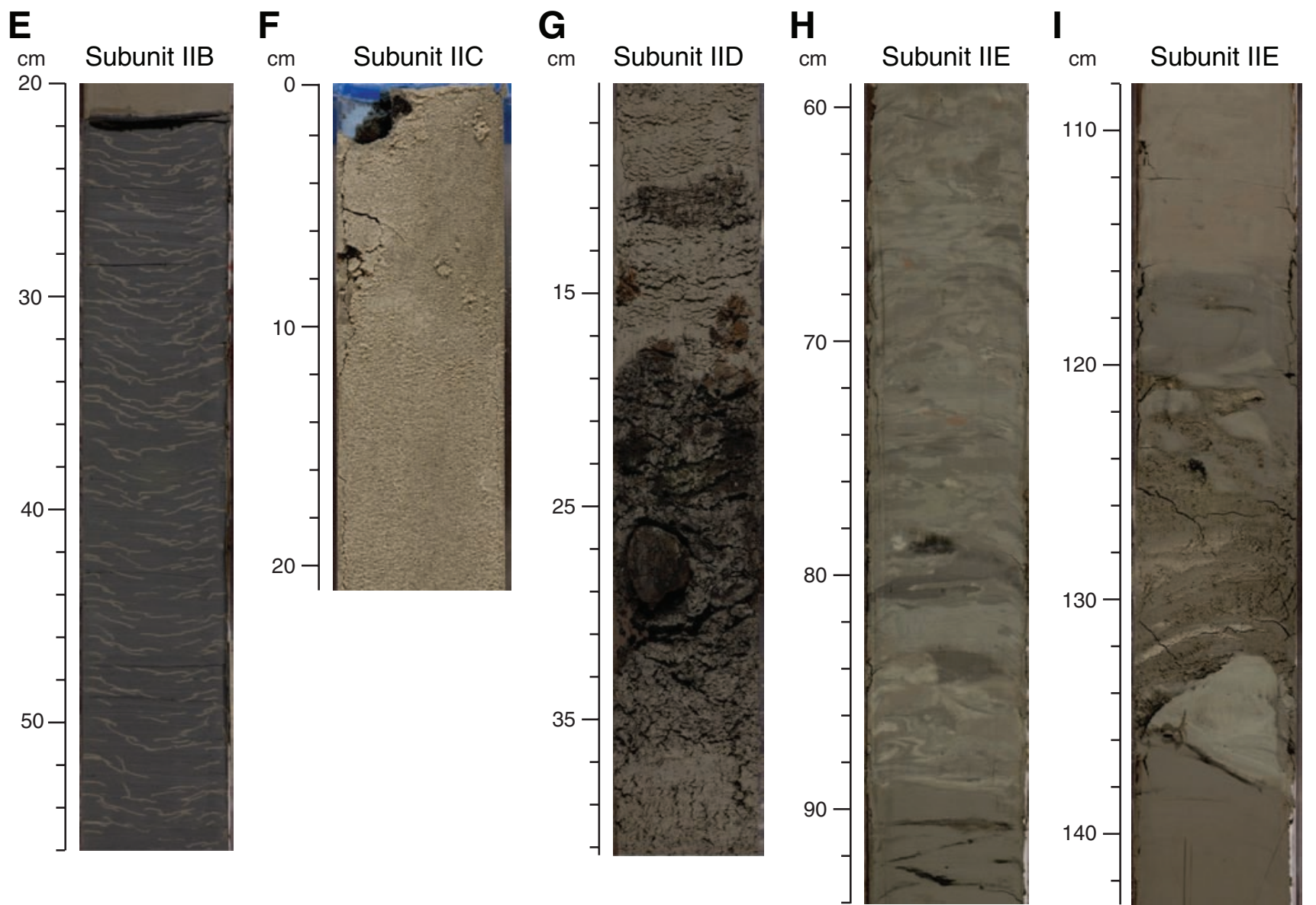
Figure F4. Correlation between core and Formation MicroScanner (FMS) borehole image for an interval in lithostratigraphic Subunit IIE interpreted as a mass transport deposit. Steep, variable dip bedding surfaces can be seen in both core and FMS images, together with clasts of various sizes.

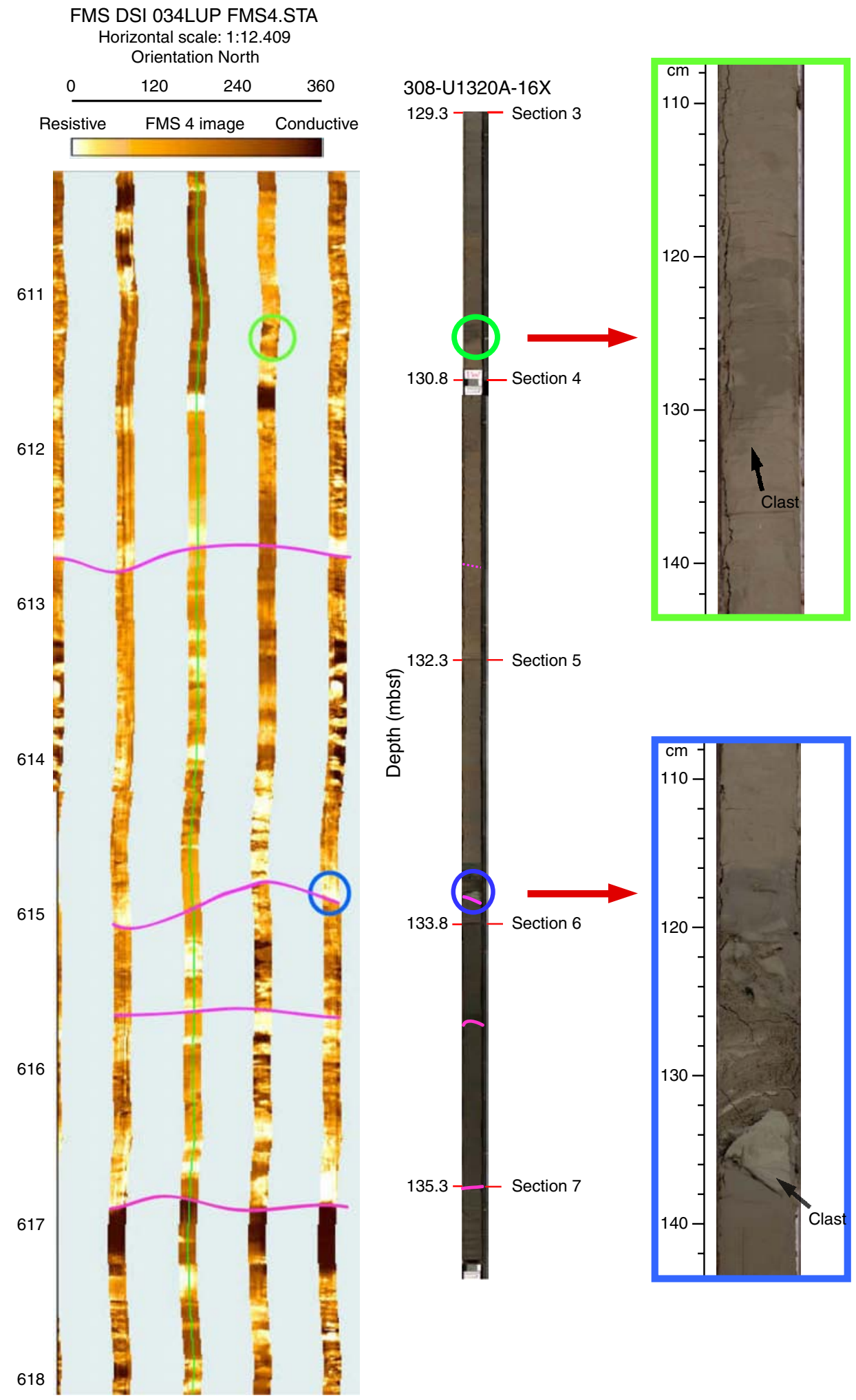


Figure F5. Lithostratigraphic Unit III. A. Sharp contact at the top of Unit III, with laminated very fine sand above and foraminifer-bearing clay below at $91 \mathrm{~cm}$ (interval 308-U1320A-17X-2, 68-102 cm). B. Laminated mud with burrows and discontinuous silt laminae at $108.5 \mathrm{~cm}$ (interval 308-U1320A-17X-2, 98-132 cm). C. Bioturbated clay, showing a large dark burrow at 124-134 cm (interval 308-U1320A-17X-6, 108-142 cm). D. Bioturbated clay showing a large dark burrow at $130-134 \mathrm{~cm}$ and scattered fine sand grains (interval 308-U1320A-17X-6, 131-150 cm). E. Bioturbated clay with fine sand-filled burrows near the base of Unit III at 80-86 cm (interval 308-U1320A-17X-7, 72-94 cm).

$\mathbf{A}_{\mathrm{cm}}$

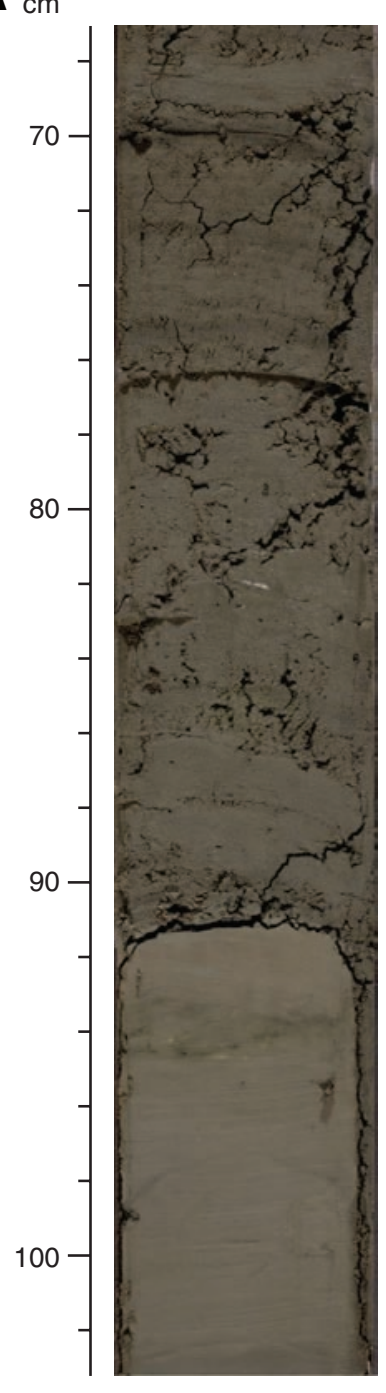

$\mathbf{B}_{\mathrm{cm}}$

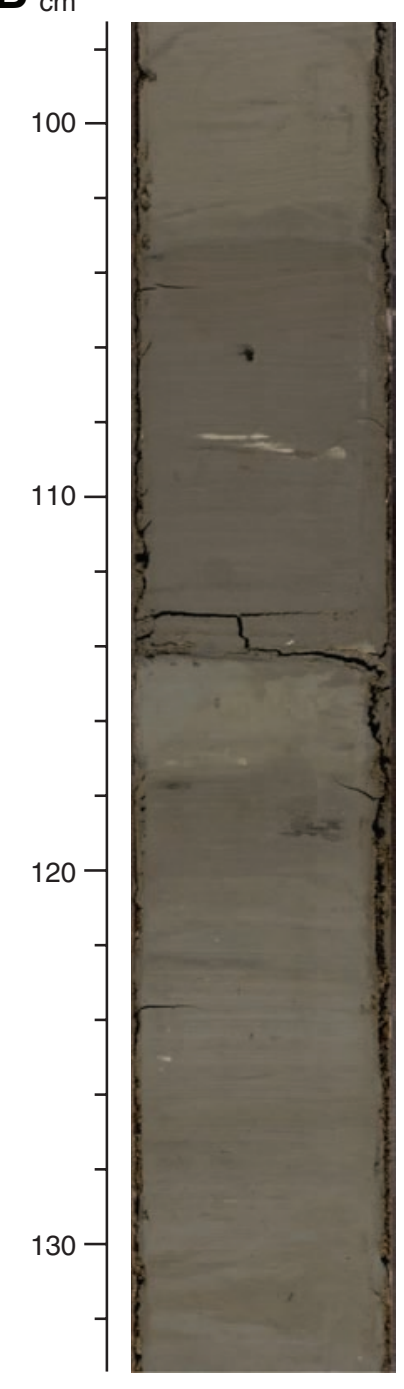

$\mathbf{C}_{\mathrm{cm}}$

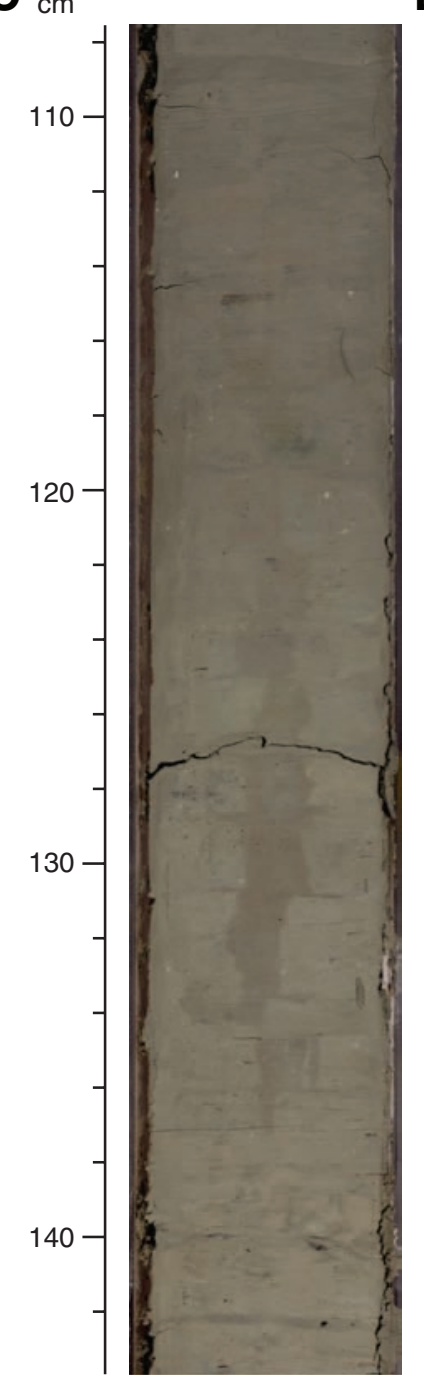

$\mathbf{E}_{\mathrm{cm}}$
D $\mathrm{cm}$

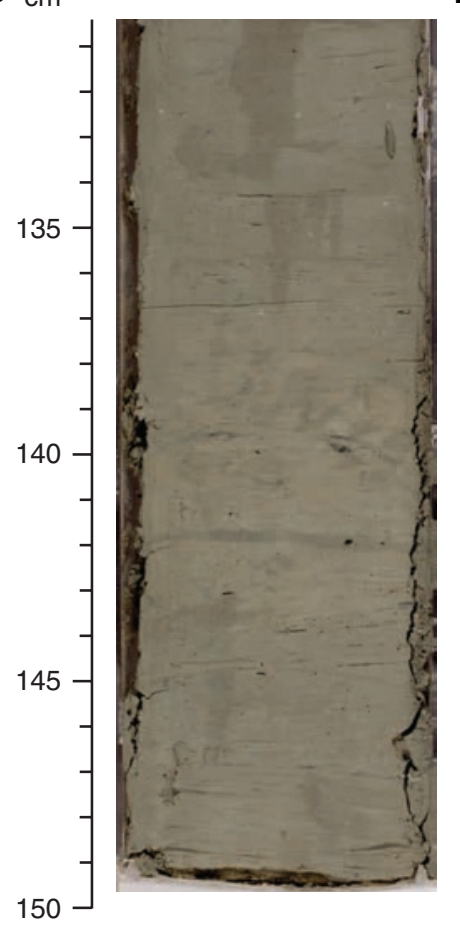

80

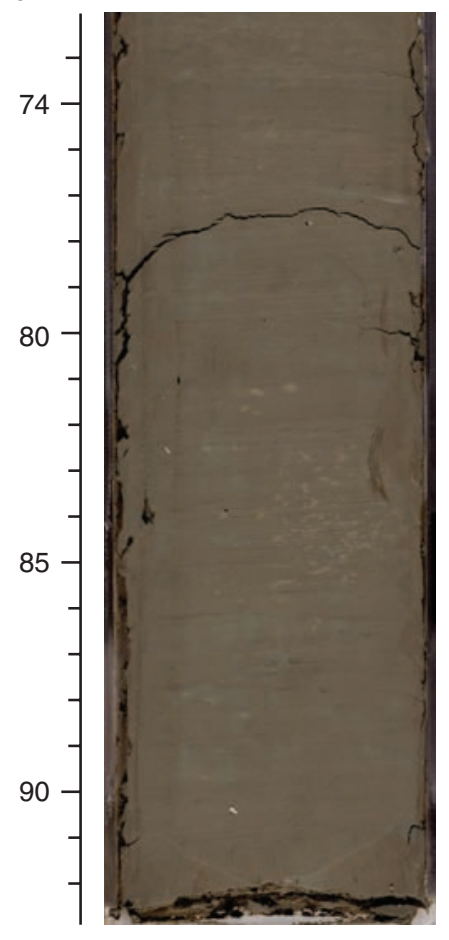


Figure F6. Ash Layer Y8 in Lithostratigraphic Unit III occurs as a small lens in Section 308-U1320A-17X-6. The original layer was probably disrupted by XCB coring. A. DIS image of Section 308-U1320A-17X-6. B. Close-up between 65 and $78 \mathrm{~cm}$. C. Smear slide photo of volcanic glass under plane-polarized light.

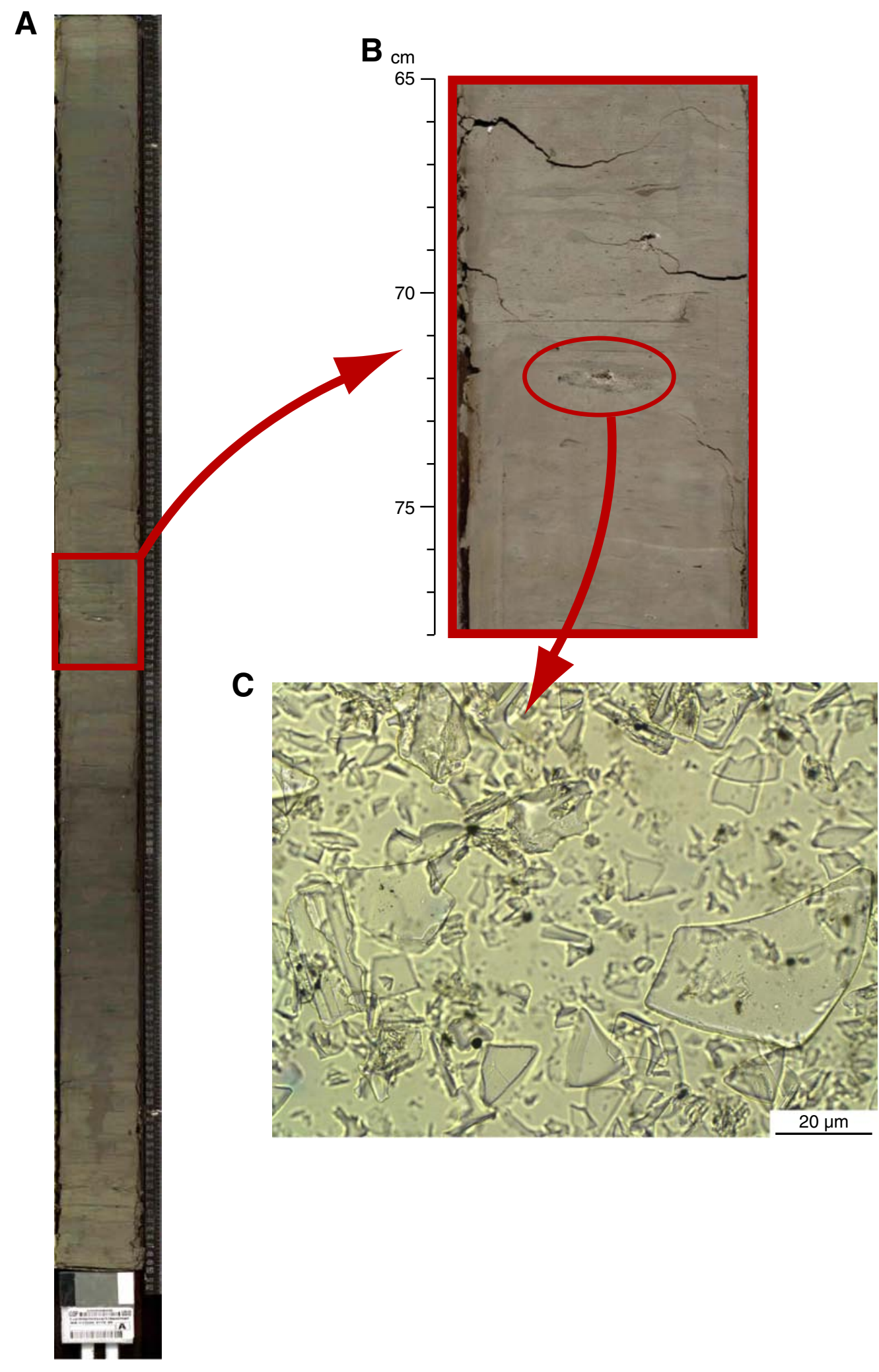


Figure F7. Lithostratigraphic Unit IV. A. Homogeneous bioturbated clay with pyrite nodules at 3.5 and $10.5 \mathrm{~cm}$ (interval 308-U1320A-18X-3, 0$20 \mathrm{~cm}$ ). B. Mottled clay (interval 308-U1320A-18X-3, 78-112 cm). C. Intensely bioturbated and color-banded mud; light colored sands at 19-21 and 35-37 cm (interval 308-U1320A-18X-5, 15-42 cm). D. Mottled clay with nodule at $88 \mathrm{~cm}$ (interval 308-U1320A-19X-2, 72-96 cm). E. Silt and color-banded mud at base of Unit IV (interval 308-U1320A-21X-1, 0-26 cm).
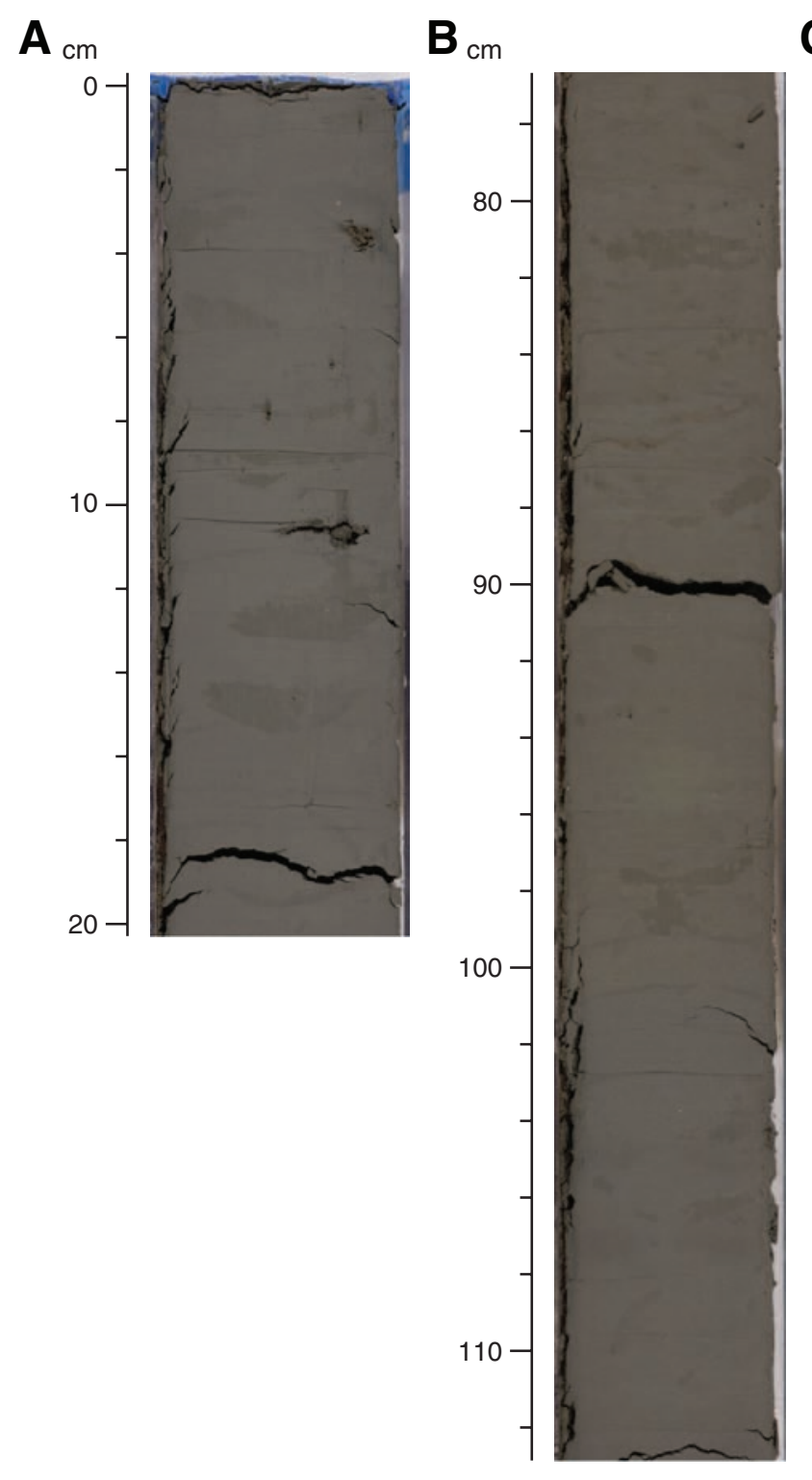

$\mathbf{C}_{\mathrm{cm}}$

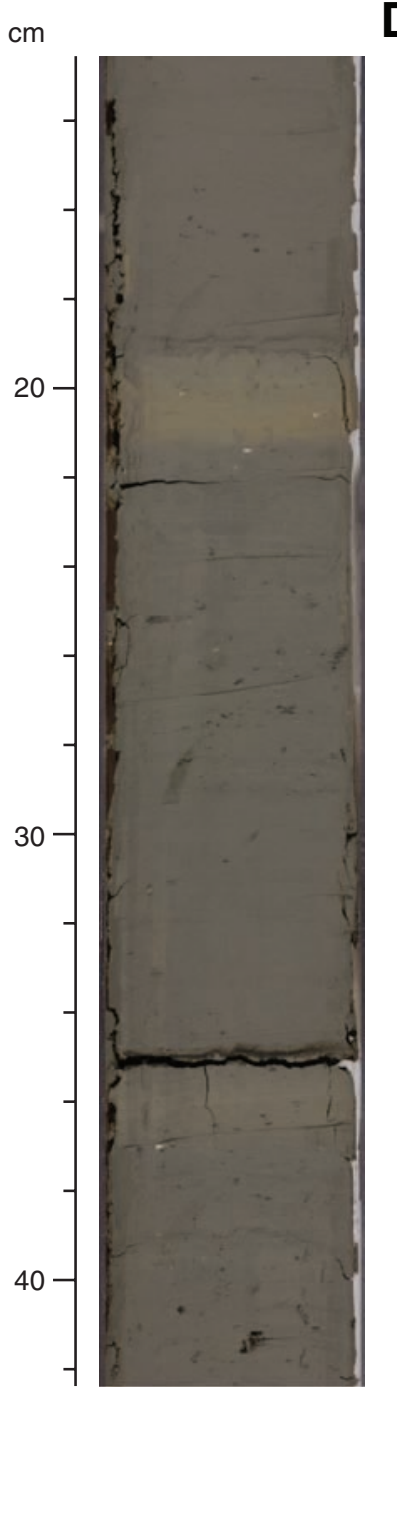

$\mathbf{D}_{\mathrm{cm}} \quad \mathbf{E}_{\mathrm{cm}}$

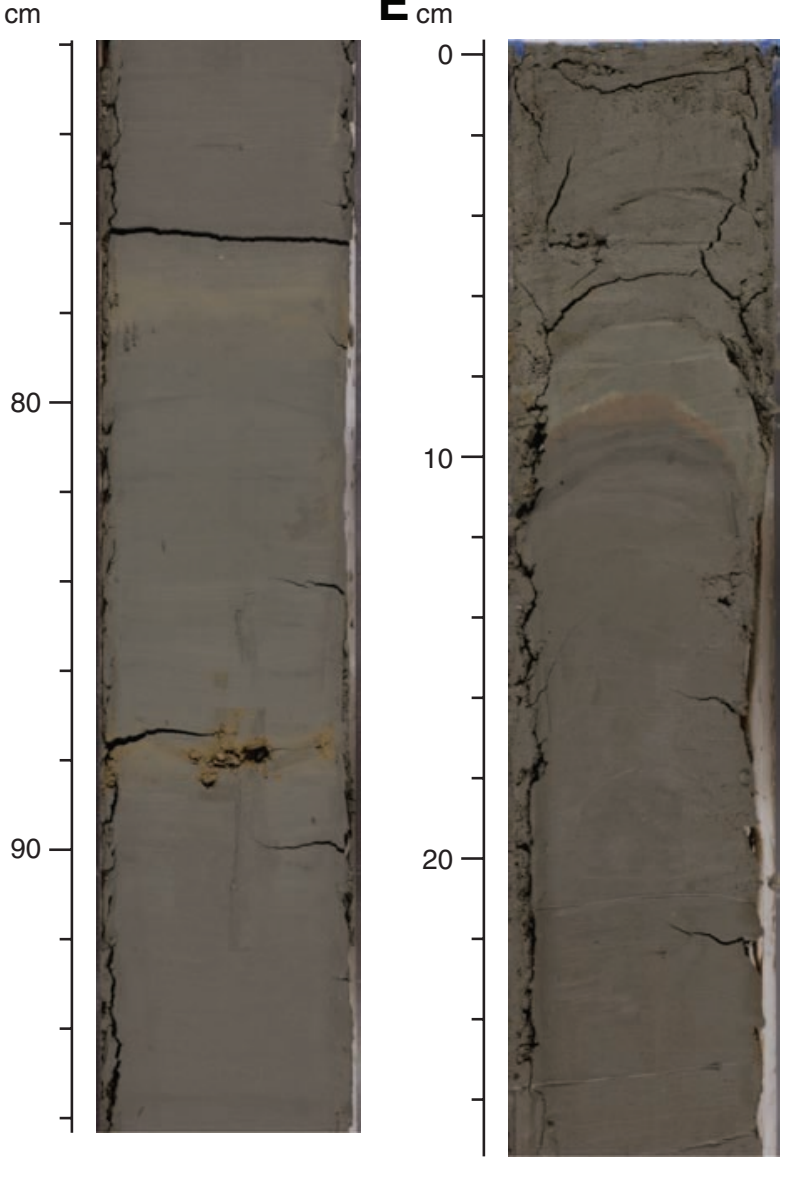


Figure F8. Lithostratigraphic Unit V. A. Homogeneous bioturbated clay (interval 308-U1320A-24X-1, 68-102 $\mathrm{cm})$. B. Laminated foraminifer-bearing clay (interval 308-U1320A-25X-1, 28-62 cm). C. Greenish gray clay with iron oxide reddish staining at 85-92 cm (interval 308-U1320A-27X-3, 62-97 cm). D. Color-banded clay with bioturbation (interval 308-U1320A-28X-3, 50-86 cm).

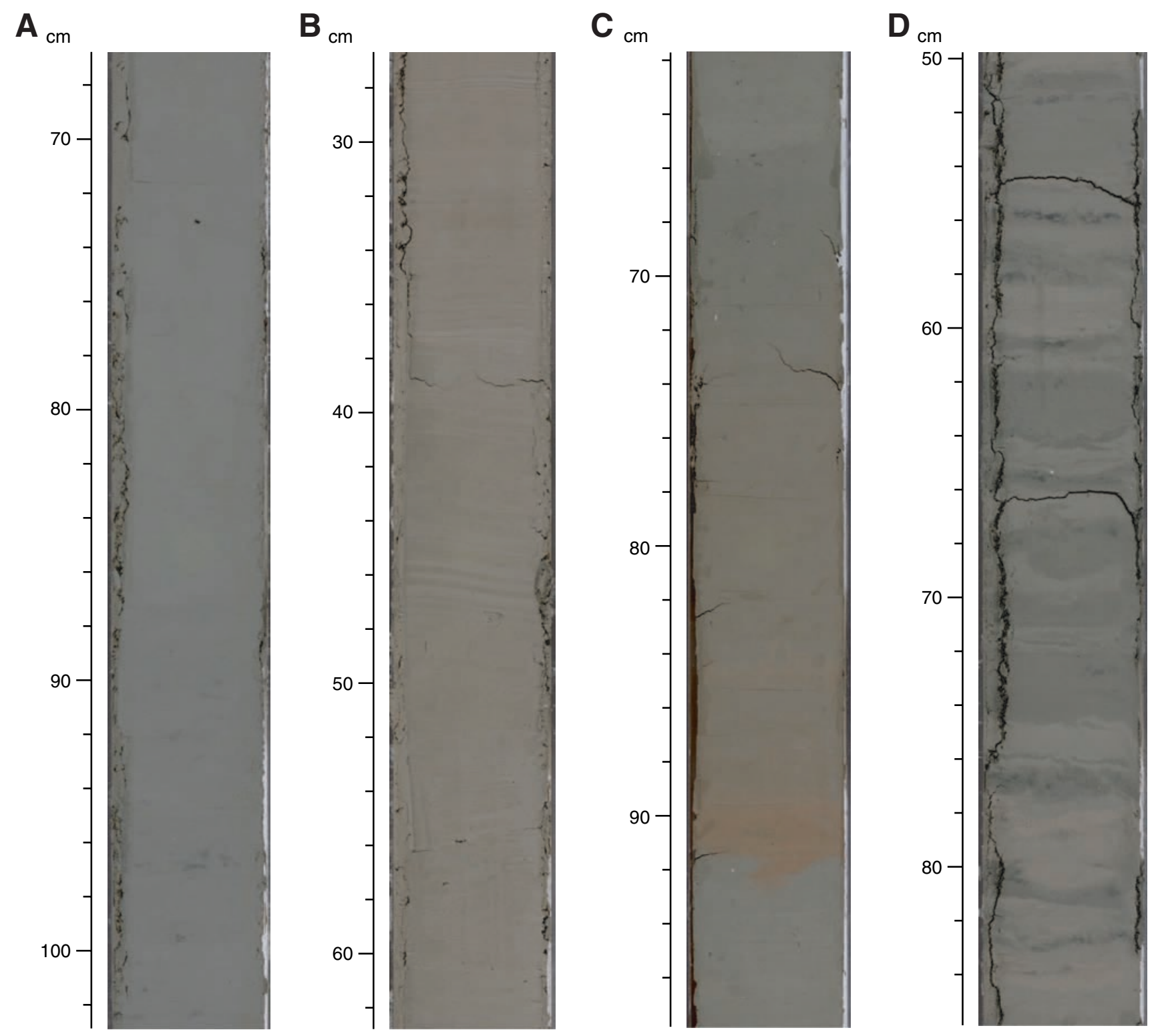


Figure F9. Summary of smear slide analyses including major (dominant) and minor lithologies.

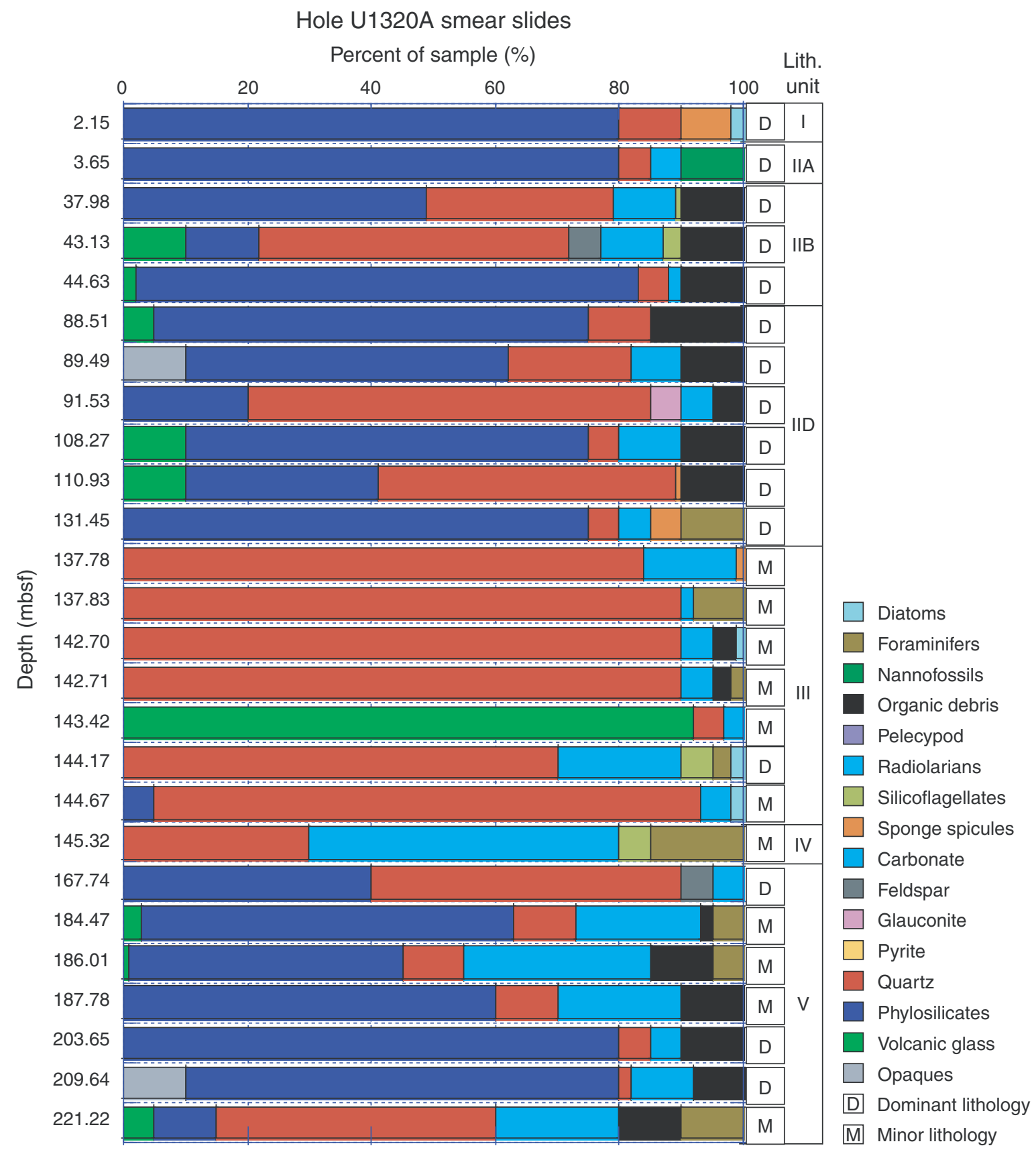


Figure F10. Biostratigraphic summary for Site U1320, along with nannofossil and foraminifer zones and assemblages, gamma radiation (GR), seismic reflectors, and lithostratigraphy. FMS = Formation MicroScanner, $\mathrm{RAB}=$ resistivity-at-the-bit.

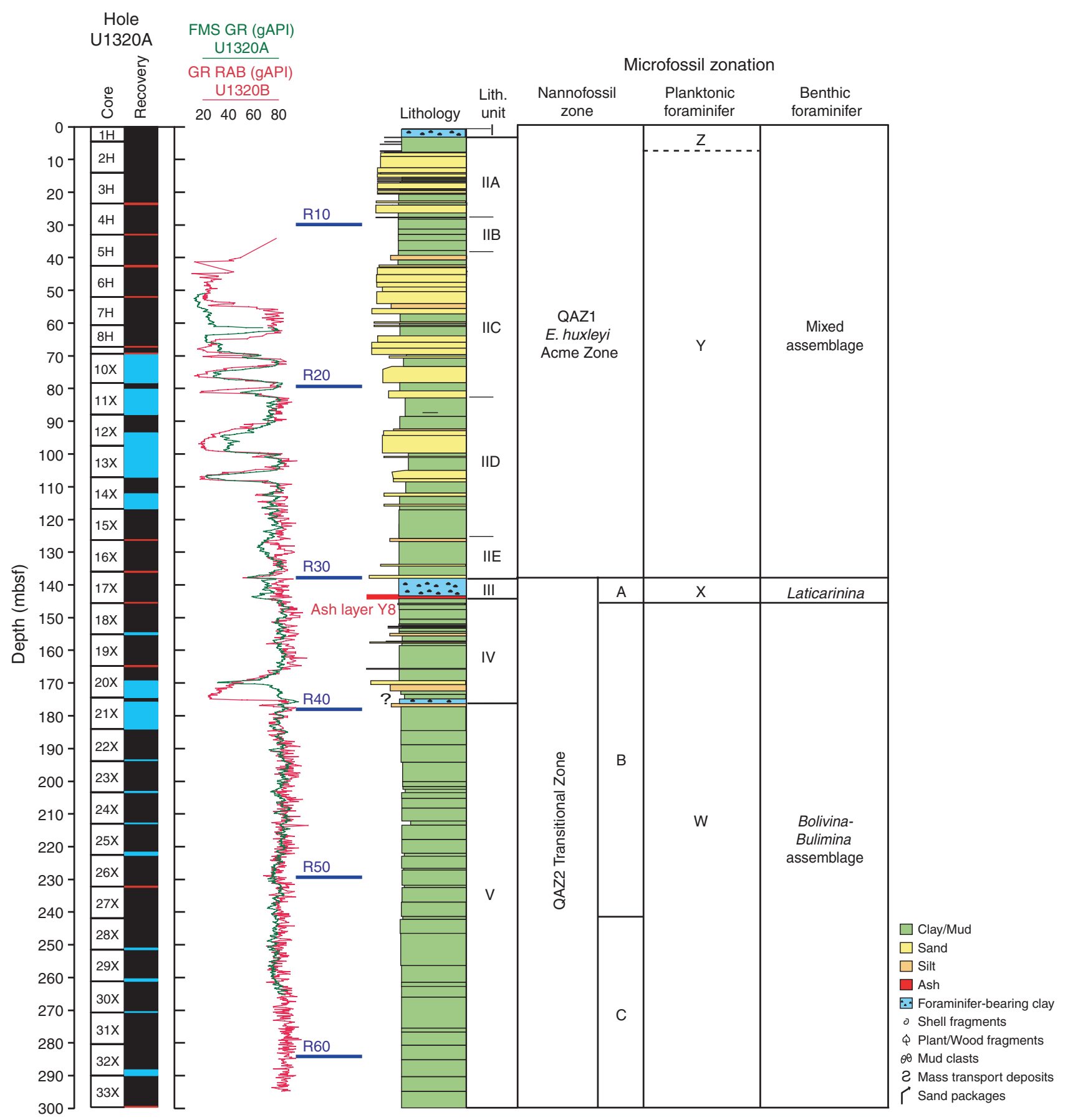




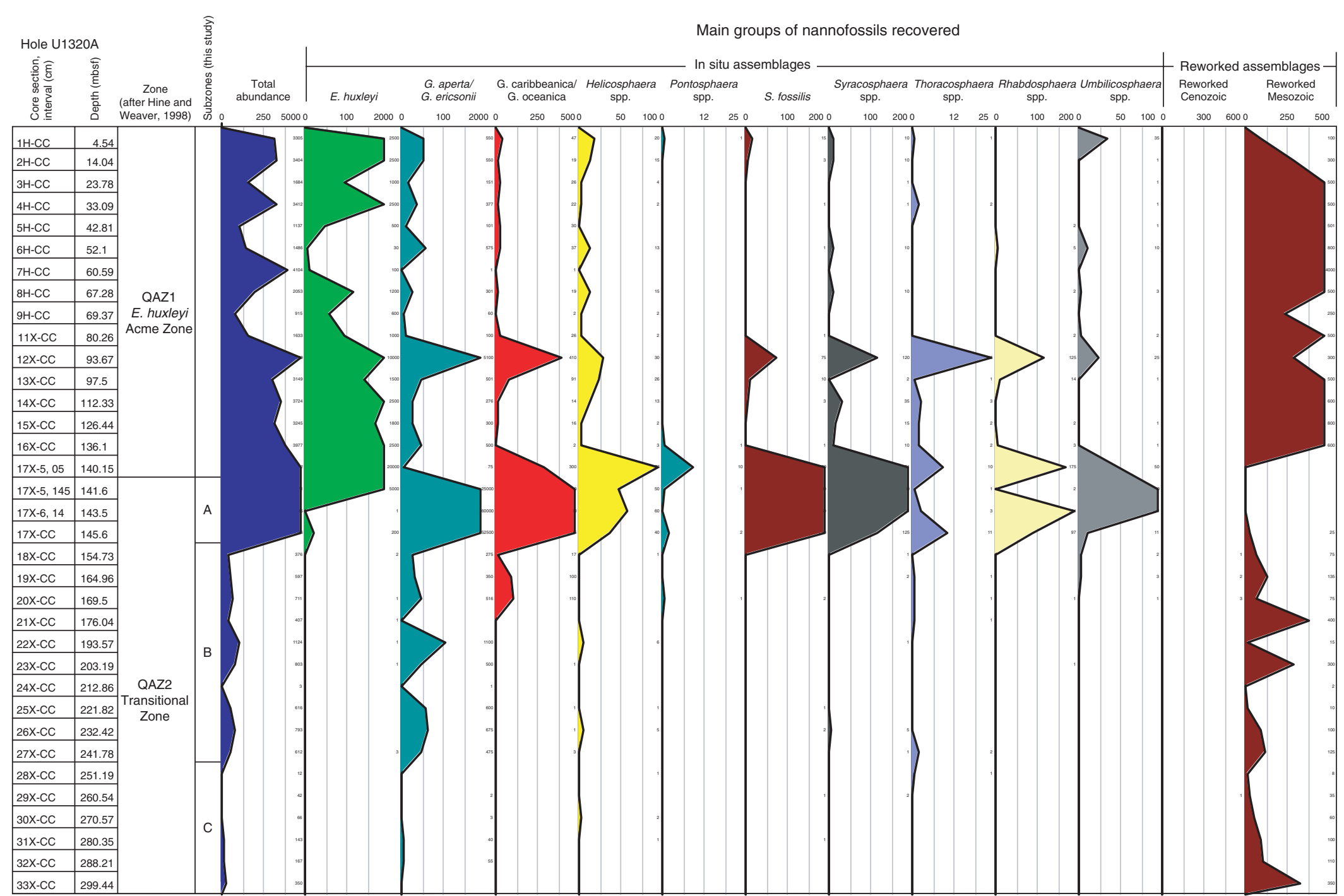




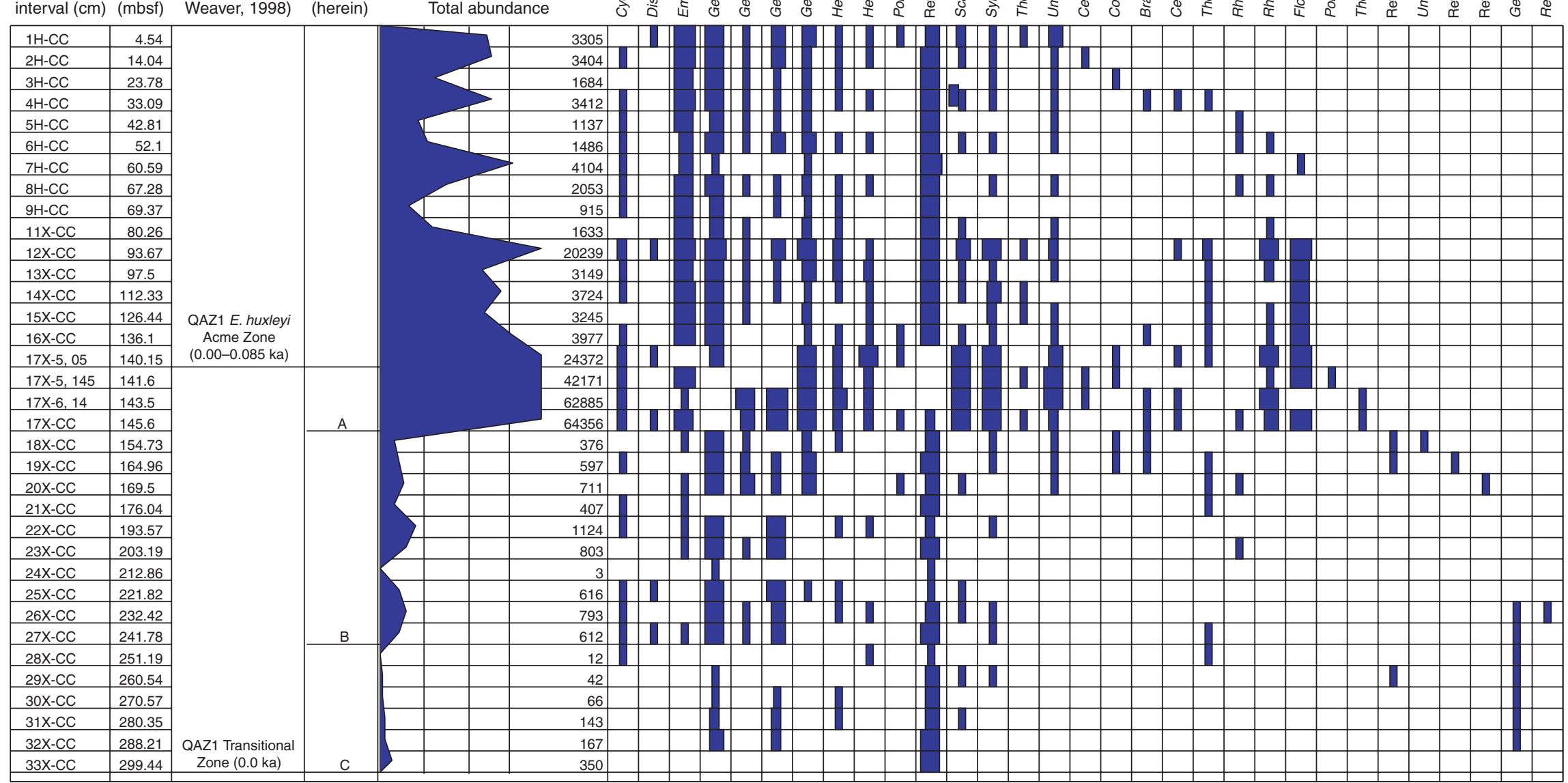
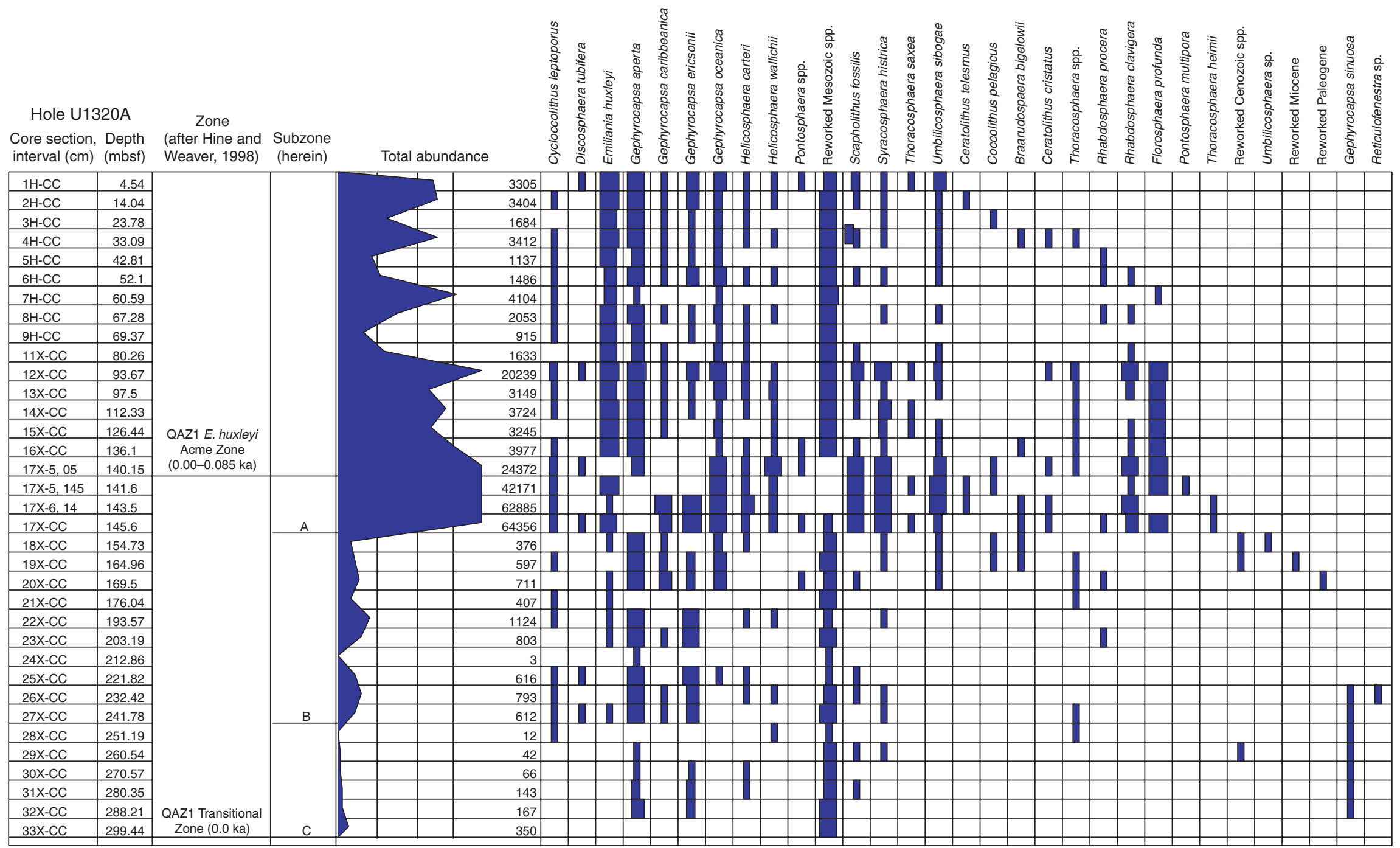
Figure F13. Planktonic foraminifer biostratigraphy and abundance of selected taxa from Hole U1320A along with lithostratigraphic units, seismic reflectors, and marine isotopic stages (MIS).

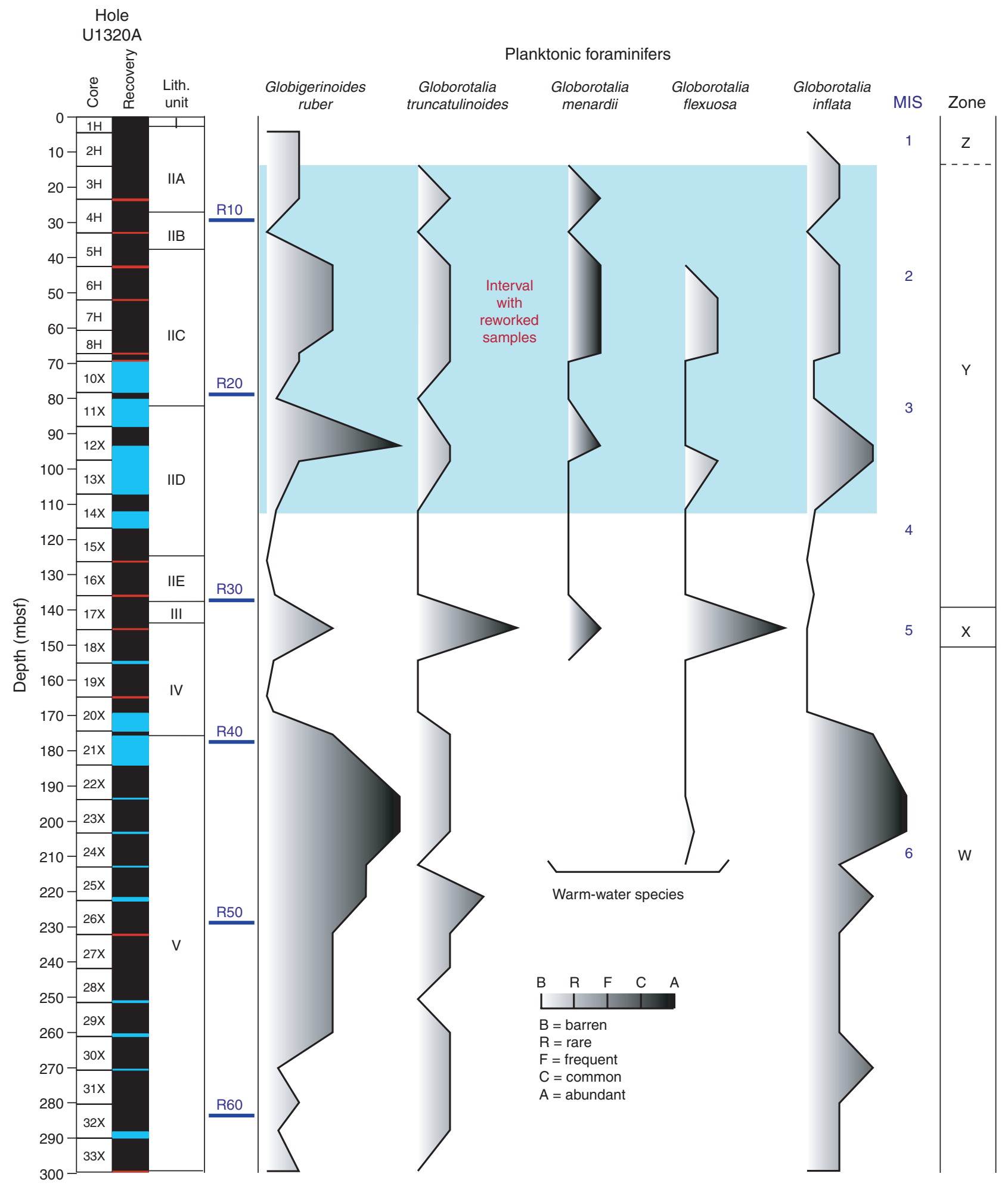


Figure F14. Distribution of selected epifaunal and infaunal benthic foraminifer species from Hole U1320A along with lithostratigraphic units, seismic reflectors, and marine isotopic stages (MIS).

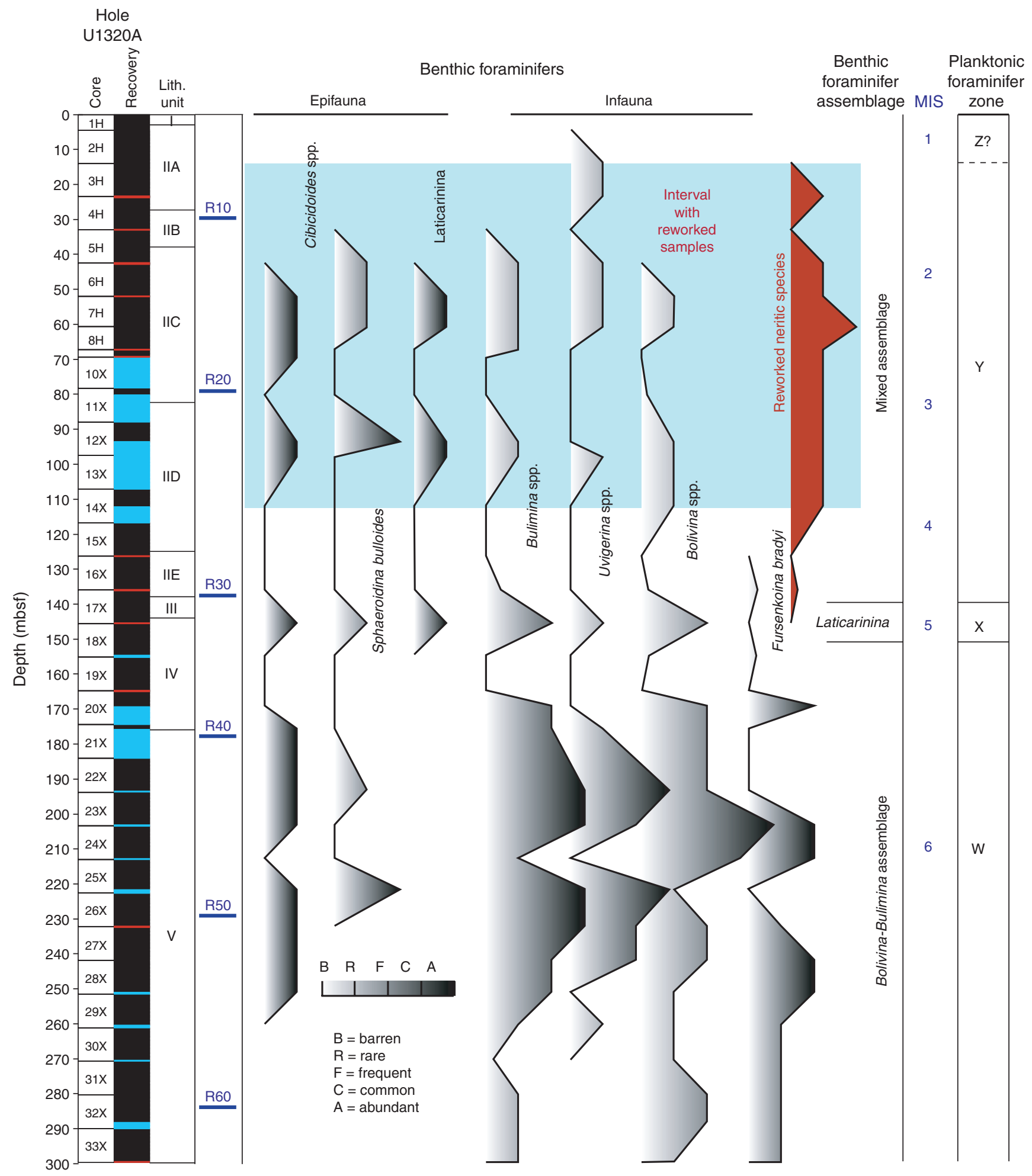


Figure F15. Microfossil and magnetostratigraphic datums and calculated sedimentation rates for Site U1320. Lithostratigraphic units and seismic reflectors are described in "Background and objectives" and "Lithostratigraphy," respectively. $\mathrm{MIS}=$ marine isotope stage. $\mathrm{LO}=$ last occurrence. $\mathrm{AL}=$ ash Layer $\mathrm{Y} 8 . \mathrm{PF}=$ planktonic foraminifer, $\mathrm{N}=$ nannofossil. $\mathrm{MTP}=$ magnetostratigraphic tie point.

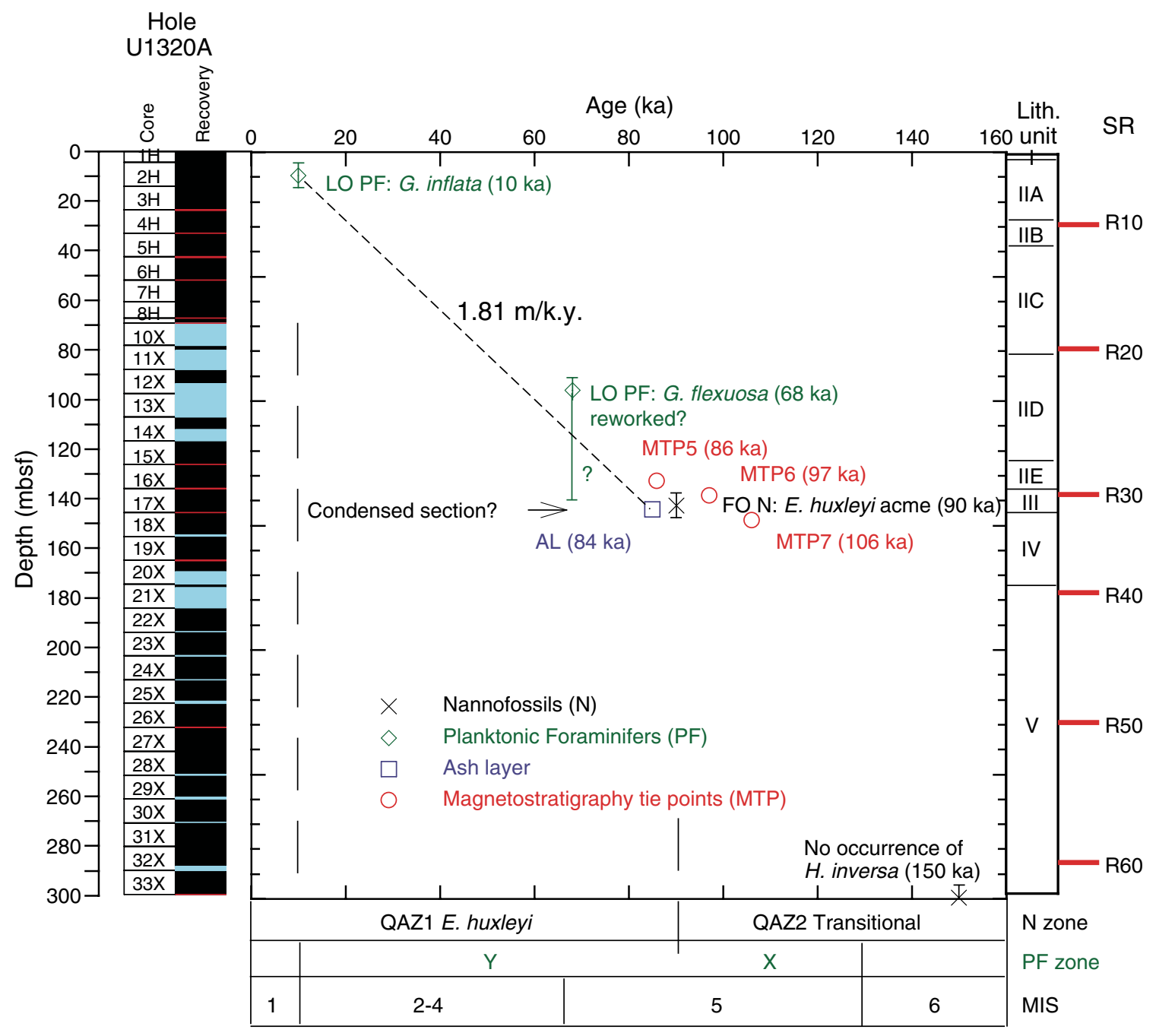


Figure F16. Uncorrected shipboard measurements on archive-half core sections of (A) natural remanent magnetization at $20 \mathrm{mT}$ AF demagnetization $\left(\mathrm{NRM}_{2 \mathrm{mT}}\right)$, (B) declination, and $(\mathrm{C})$ inclination. Depths have been corrected for voids in the core; paleomagnetic intervals, lithostratigraphic units, and seismic reflectors $(\mathrm{SF}=$ seafloor) are also shown.

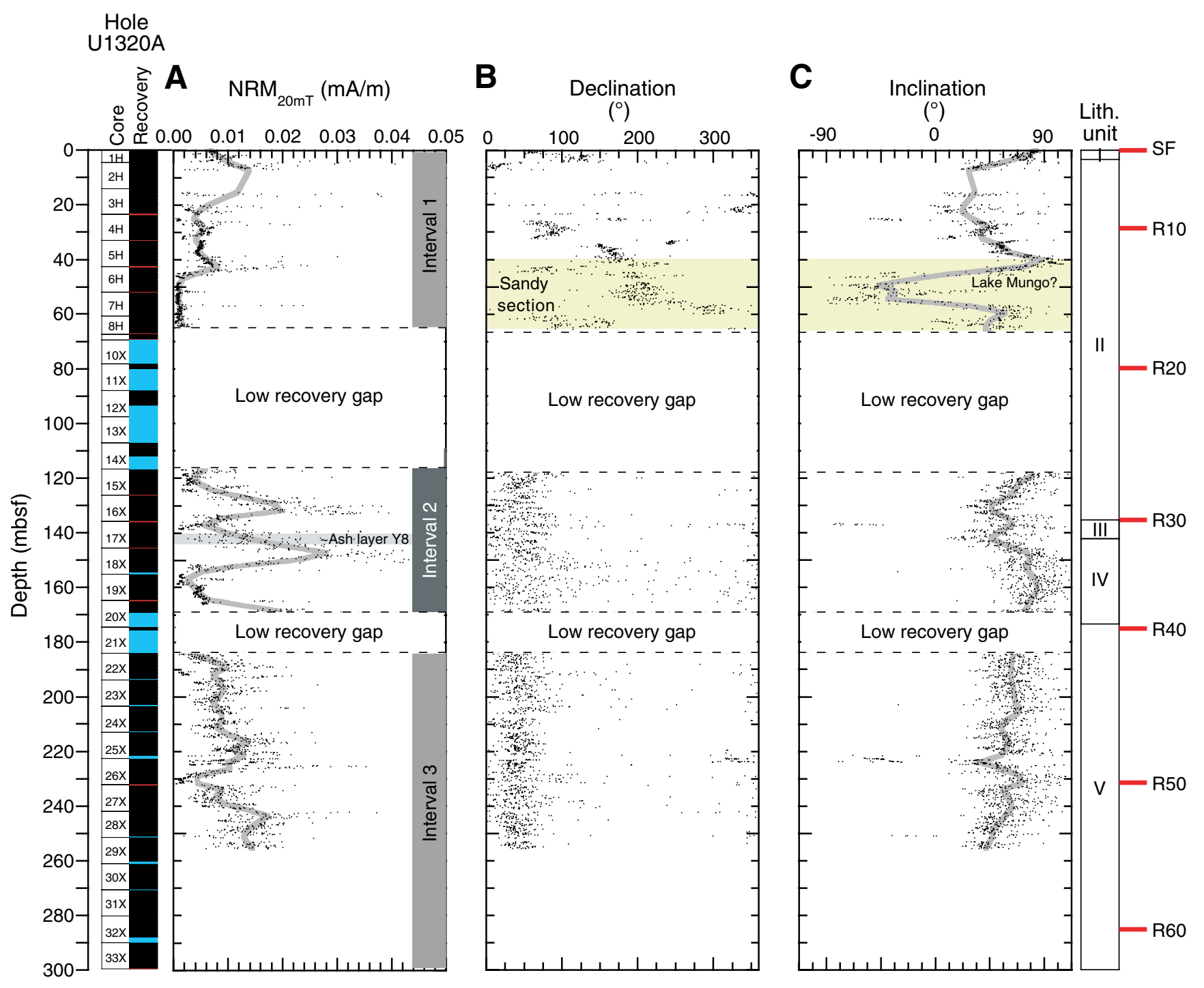


Figure F17. Preliminary magnetostratigraphic age model for Hole U1320A. A. $\delta^{18} \mathrm{O}$ record (Bassinot et al., 1994) vs. age. Marine isotopes Stages 3.1 through 5.5 are shown. B. NRM $\mathrm{N}_{20 \mathrm{~m}}$ intensity, showing the graphical correlation of the magnetostratigraphic tie points (MTP2-MTP12) with marine isotopic stages. C. MS2F sensor magnetic point susceptibility $(\kappa)$ performed on archive-half cores at $10 \mathrm{~cm}$ resolution. D. Multisensor track (MST) $\mathrm{k}$ performed on whole cores at $1 \mathrm{~cm}$ resolution measurements. E. Bulk density. Depths have been corrected for voids in the core; lithostratigraphic units, and seismic reflectors $(\mathrm{SF}=$ seafloor $)$ are also shown.
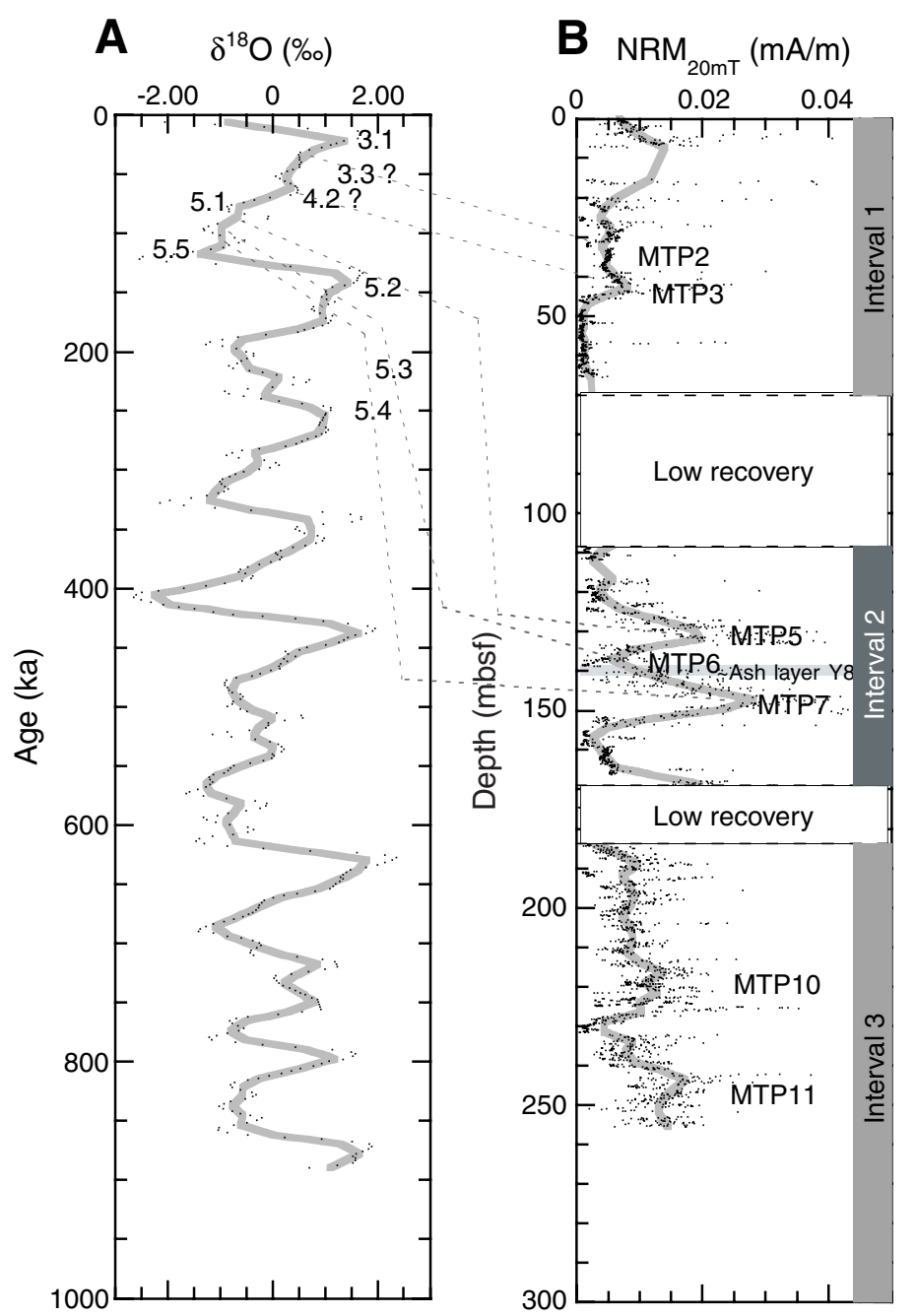

C $\kappa\left(10^{-5} \mathrm{SI}\right) \mathrm{MS} 2 \mathrm{~F}$

D $\kappa\left(10^{-5} \mathrm{SI}\right) \mathrm{MST}$

E Bulk density $\left(\mathrm{g} / \mathrm{cm}^{3}\right)$
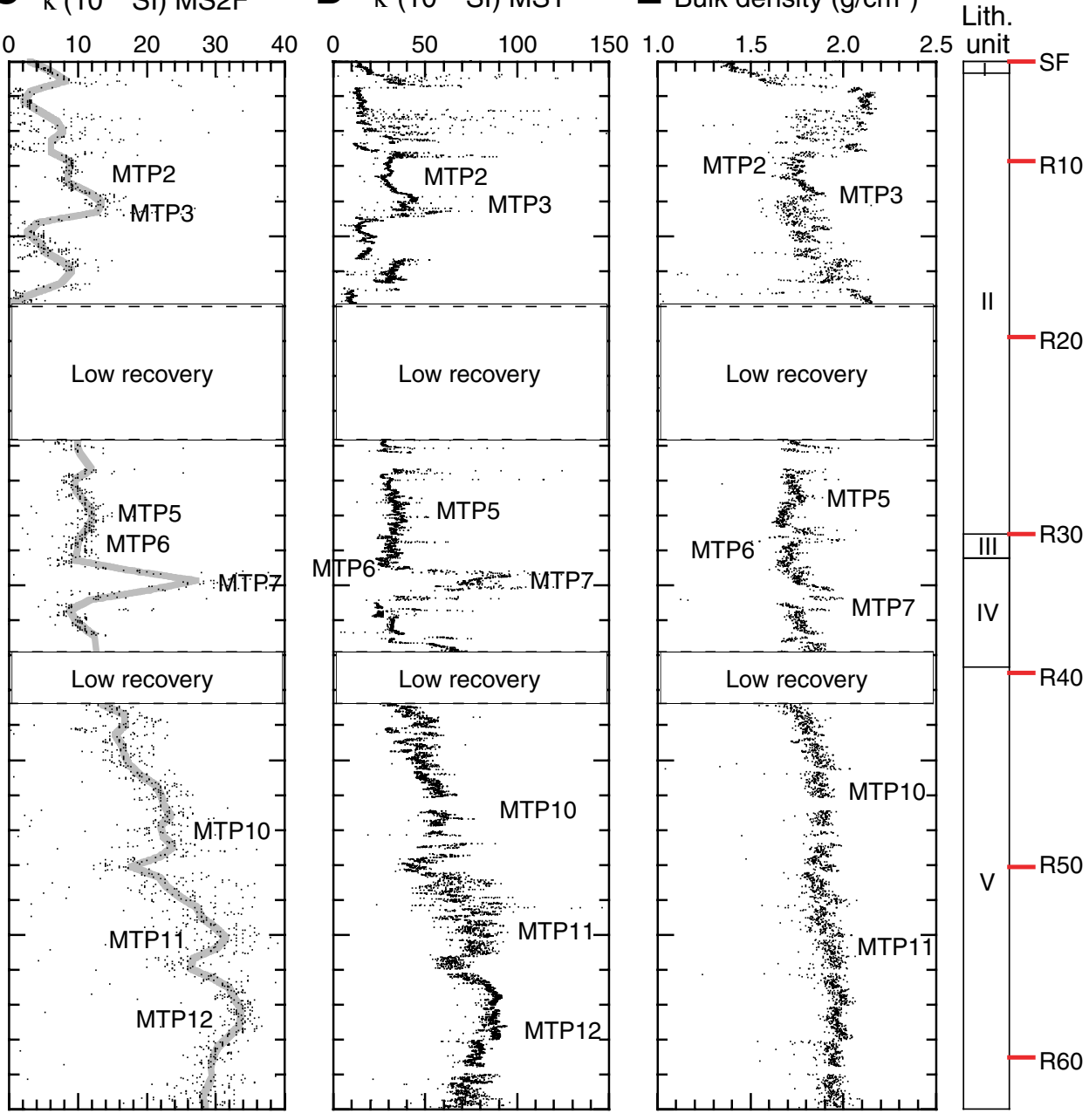

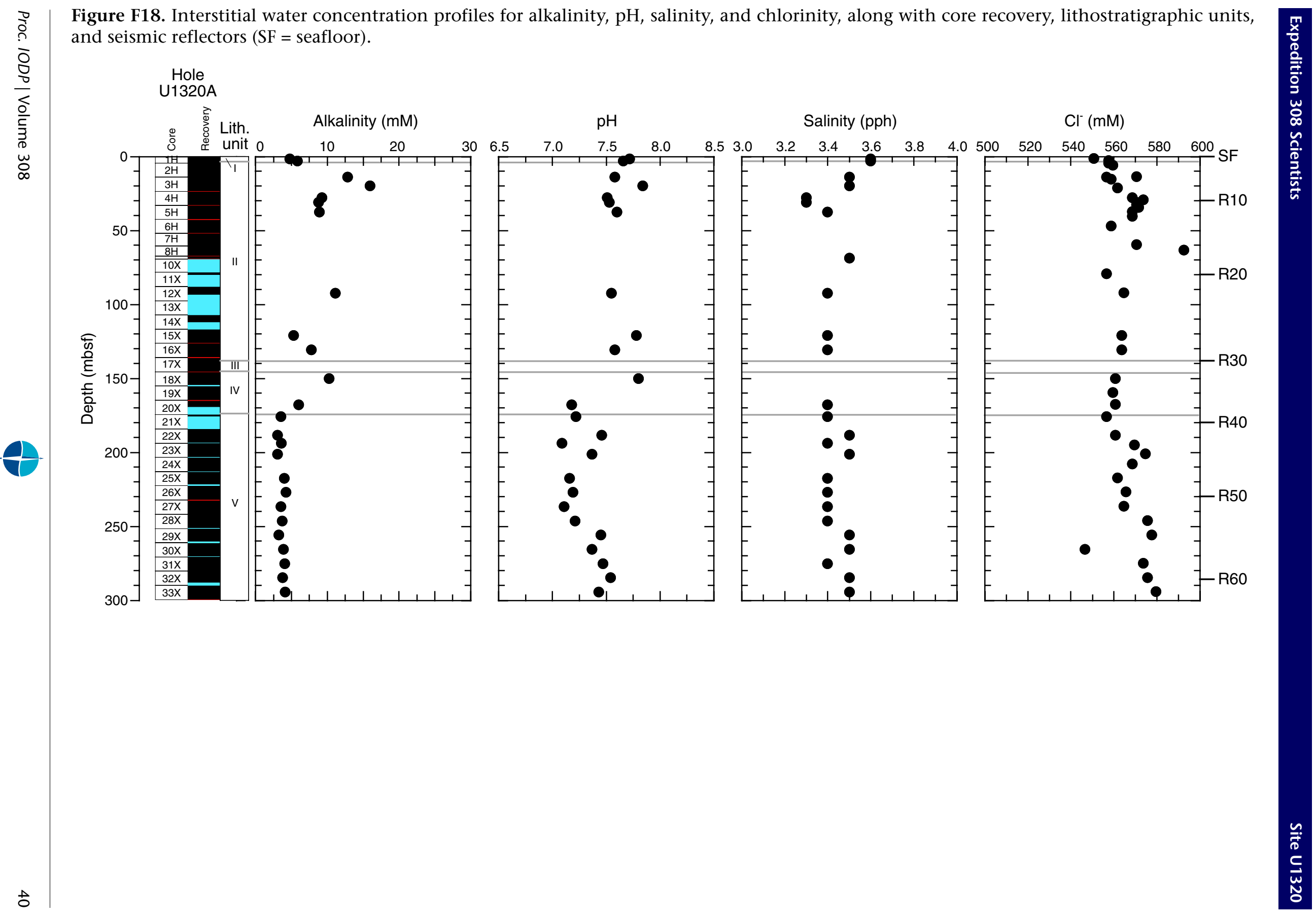

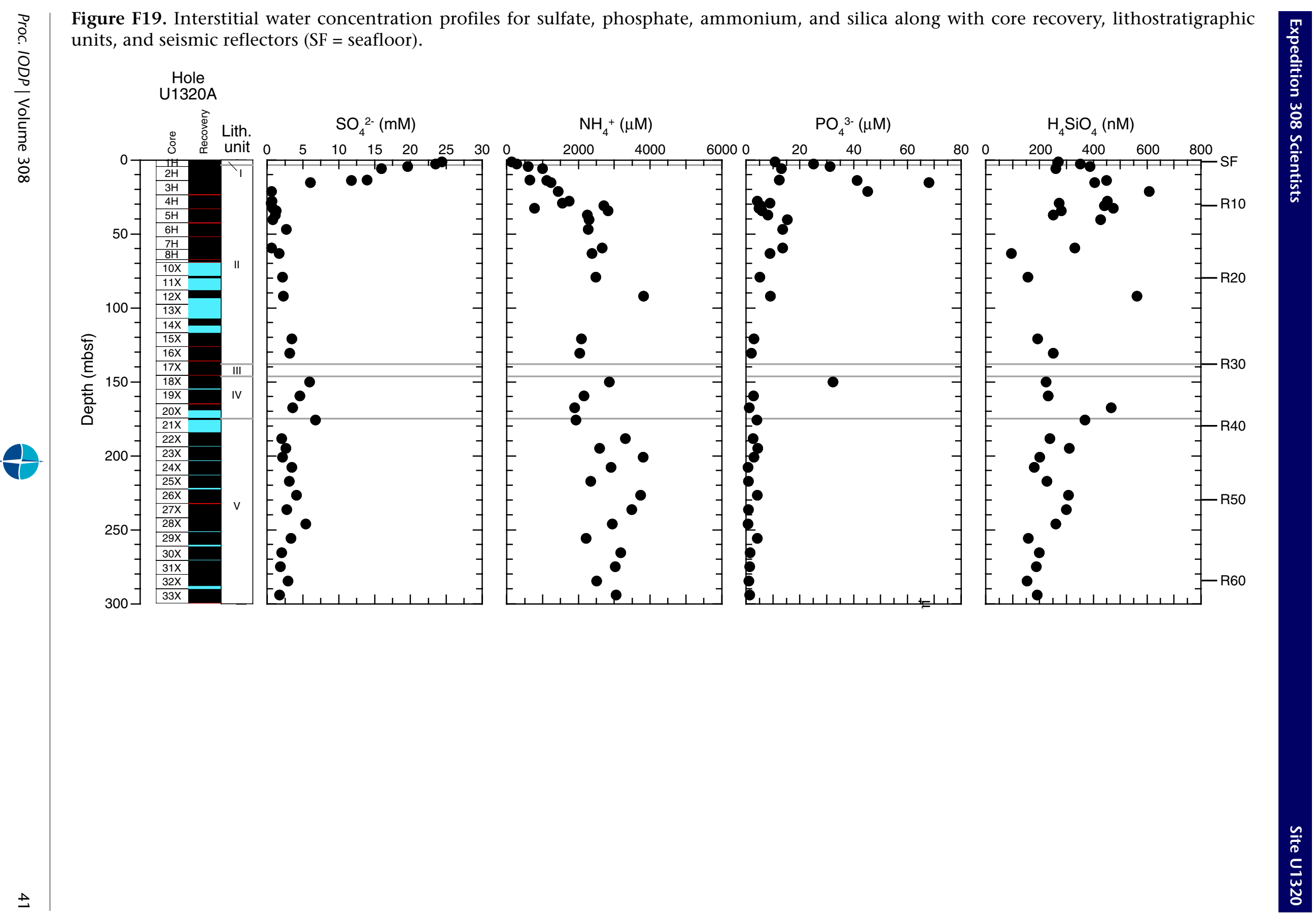

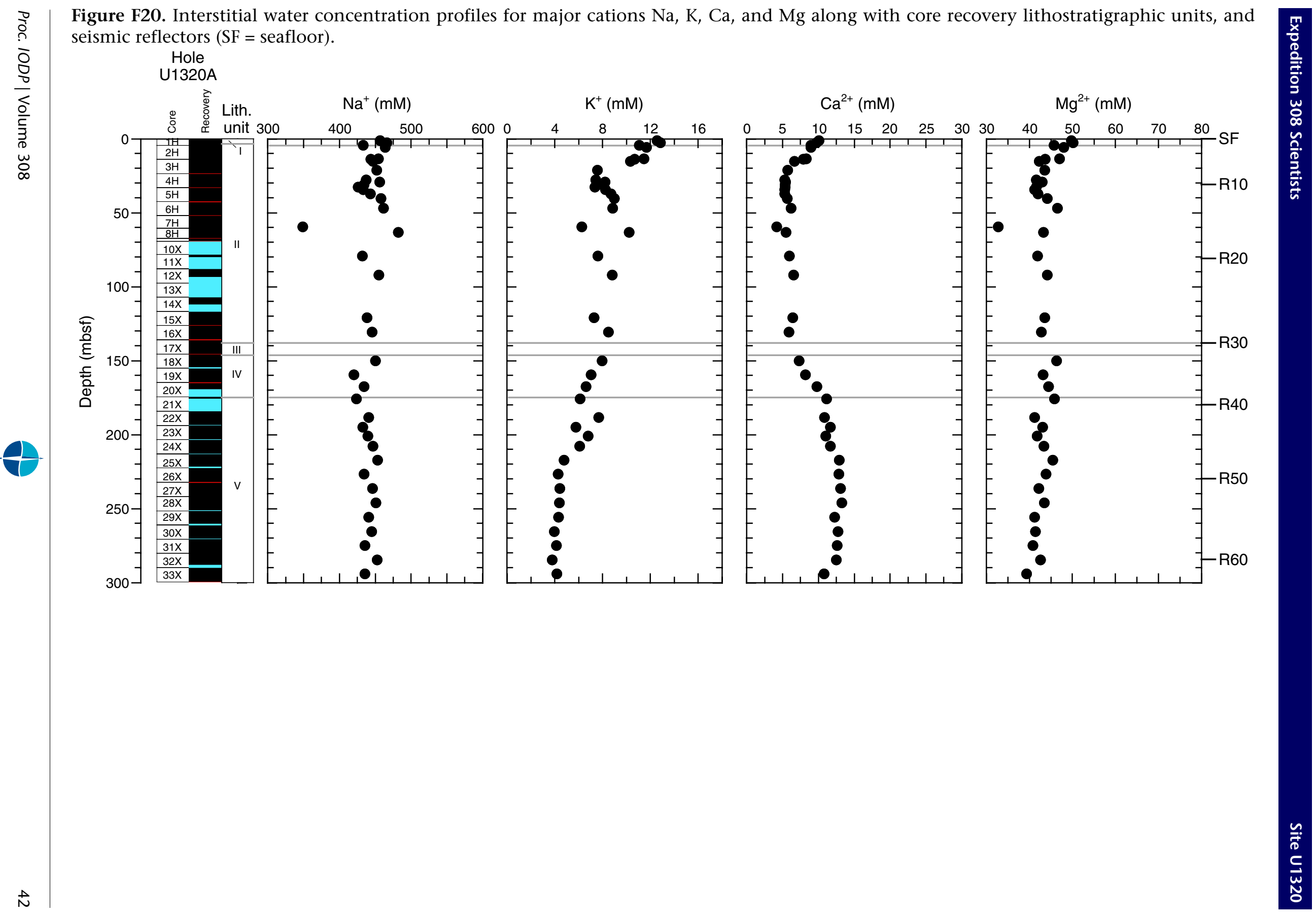
Figure F21. Downhole variations in trace metals $\left(\mathrm{B}^{3+}, \mathrm{Li}^{+}\right.$, and $\left.\mathrm{Sr}^{2+}\right)$ along with core recovery, lithostratigraphic units, and seismic reflectors $(\mathrm{SF}=$ seafloor). (Continued on next page.)

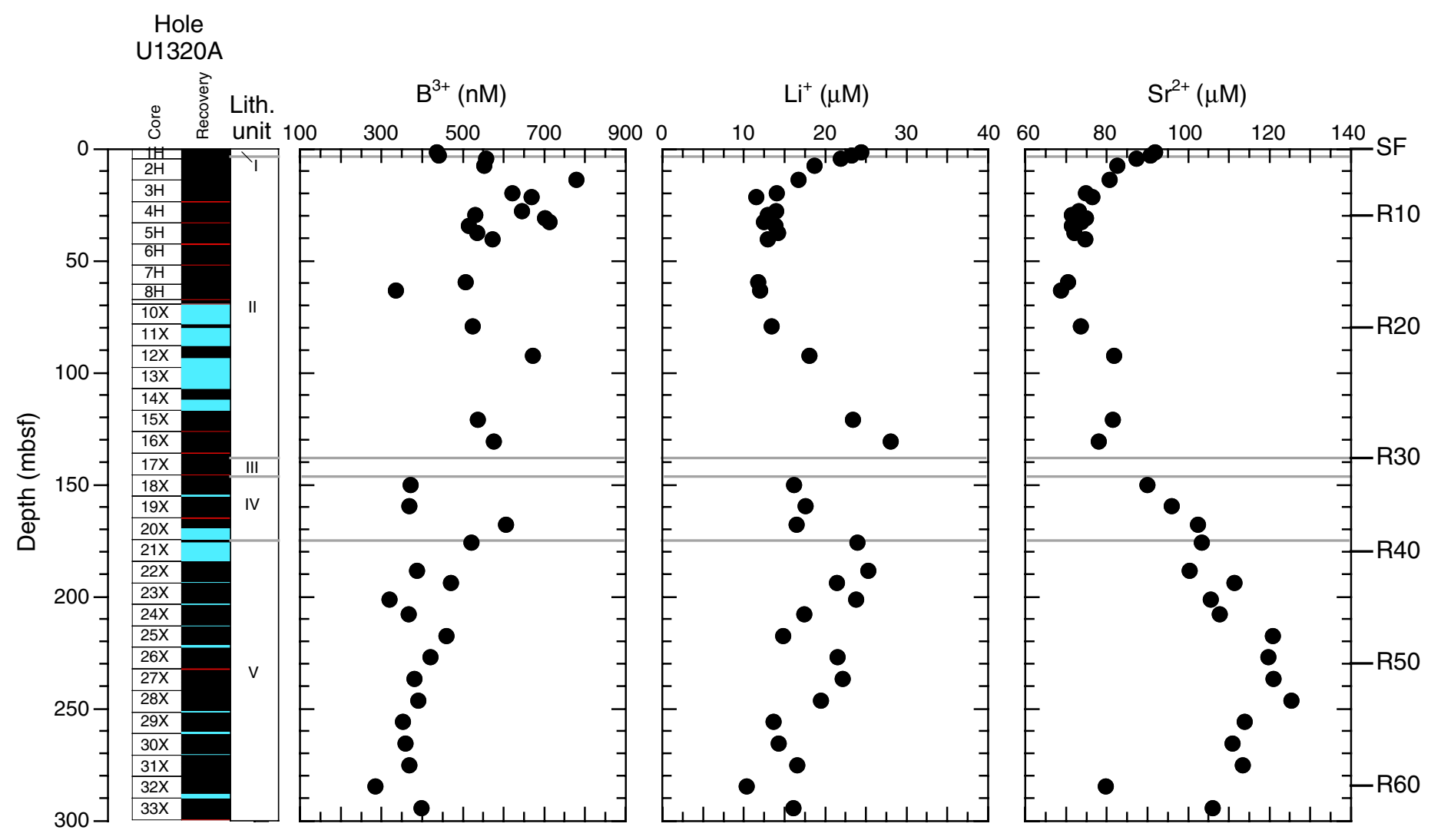




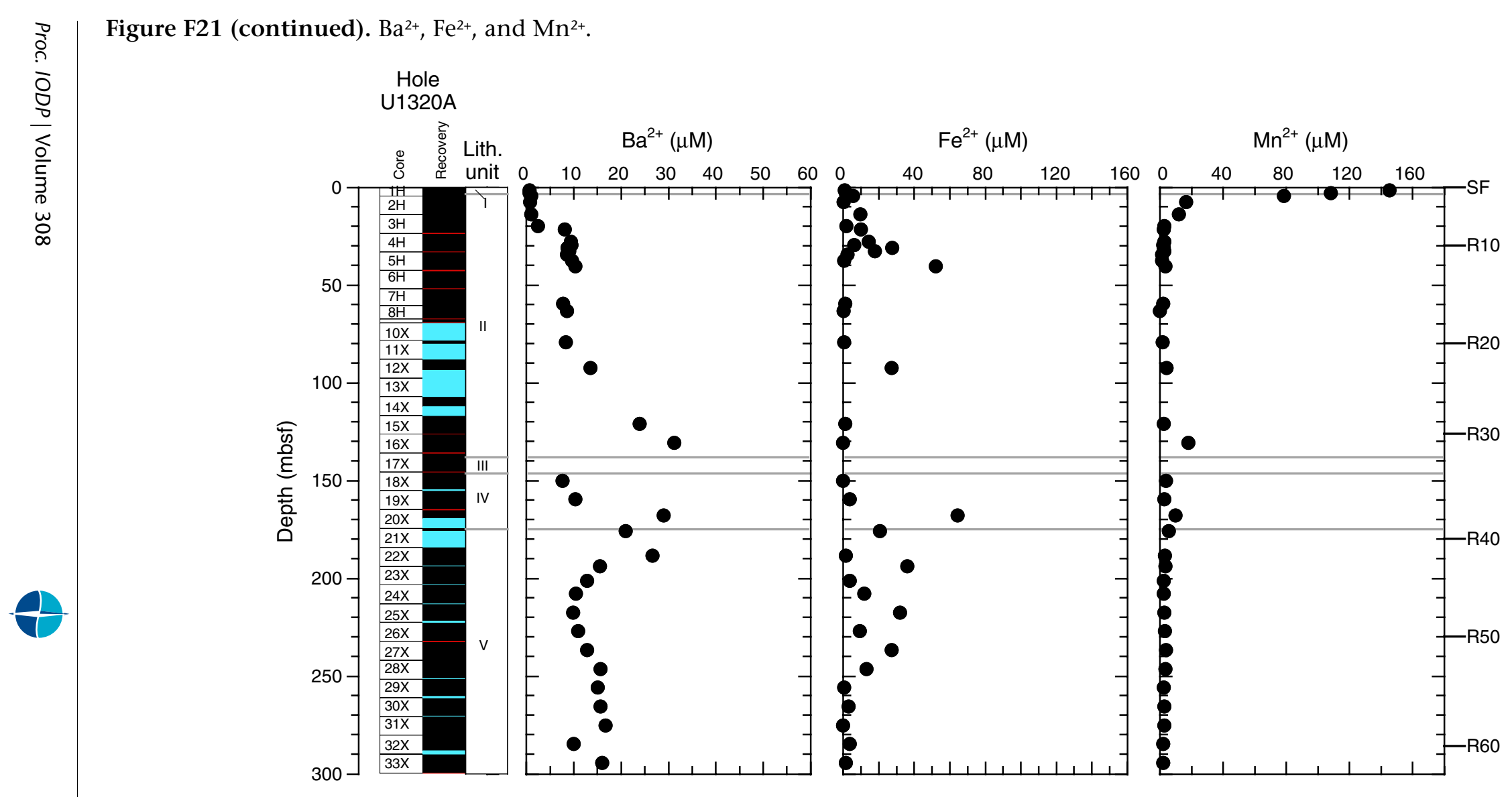


Figure F22. Downhole variations in total inorganic carbon (TIC), calcium carbonate $\left(\mathrm{CaCO}_{3}\right)$, total organic carbon (TOC), total nitrogen (TN), C/ $\mathrm{N}$, and total hydrogen $(\mathrm{TH})$ in sediments from Hole U1320A along with core recovery, lithostratigraphic units, and seismic reflectors $(\mathrm{SF}=$ seafloor).
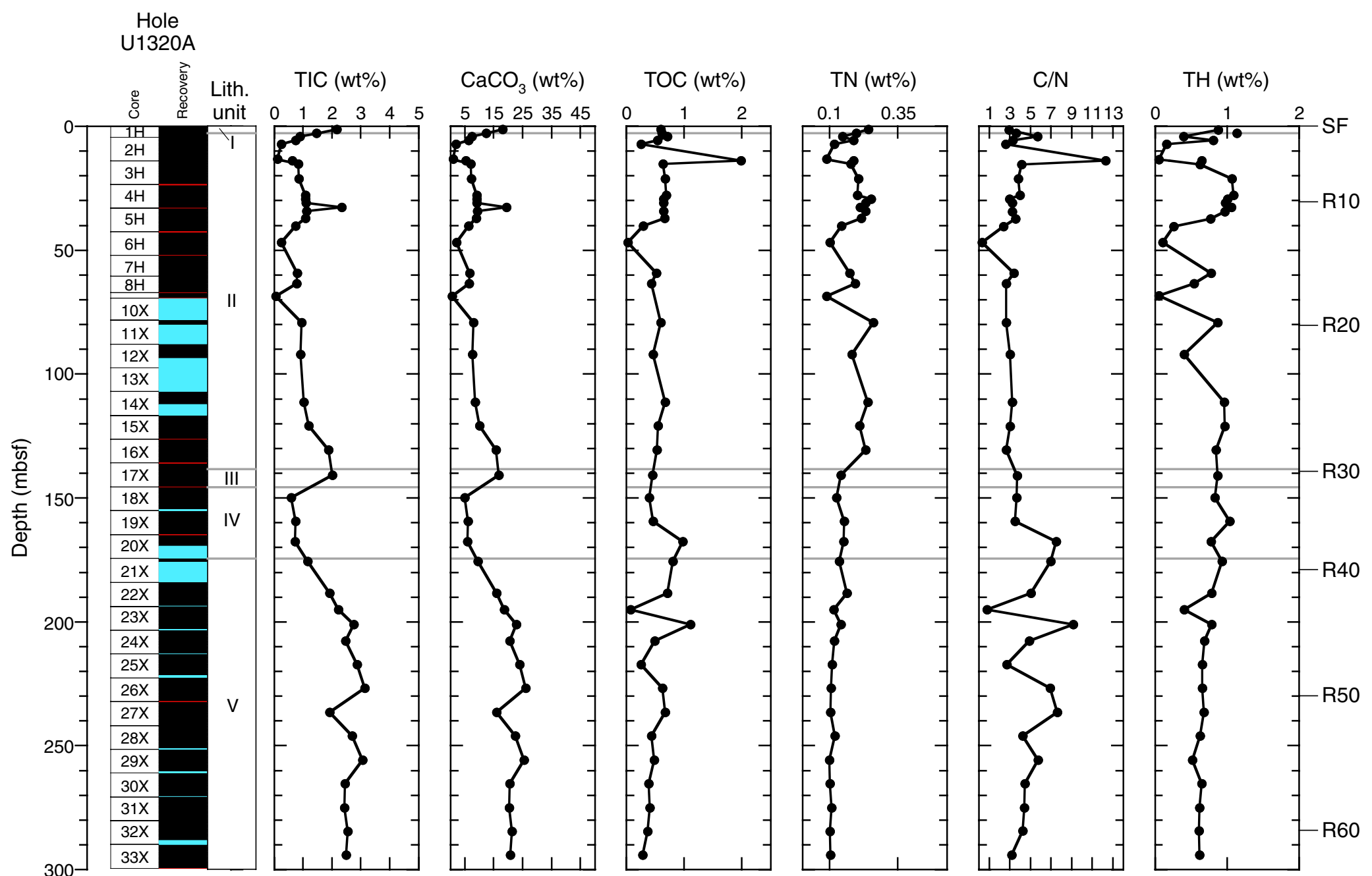
Figure F23. Headspace gas concentrations of methane and ethane in Hole U1320A along with core recovery, lithostratigraphic units, and seismic reflectors ( $\mathrm{SF}=$ seafloor).

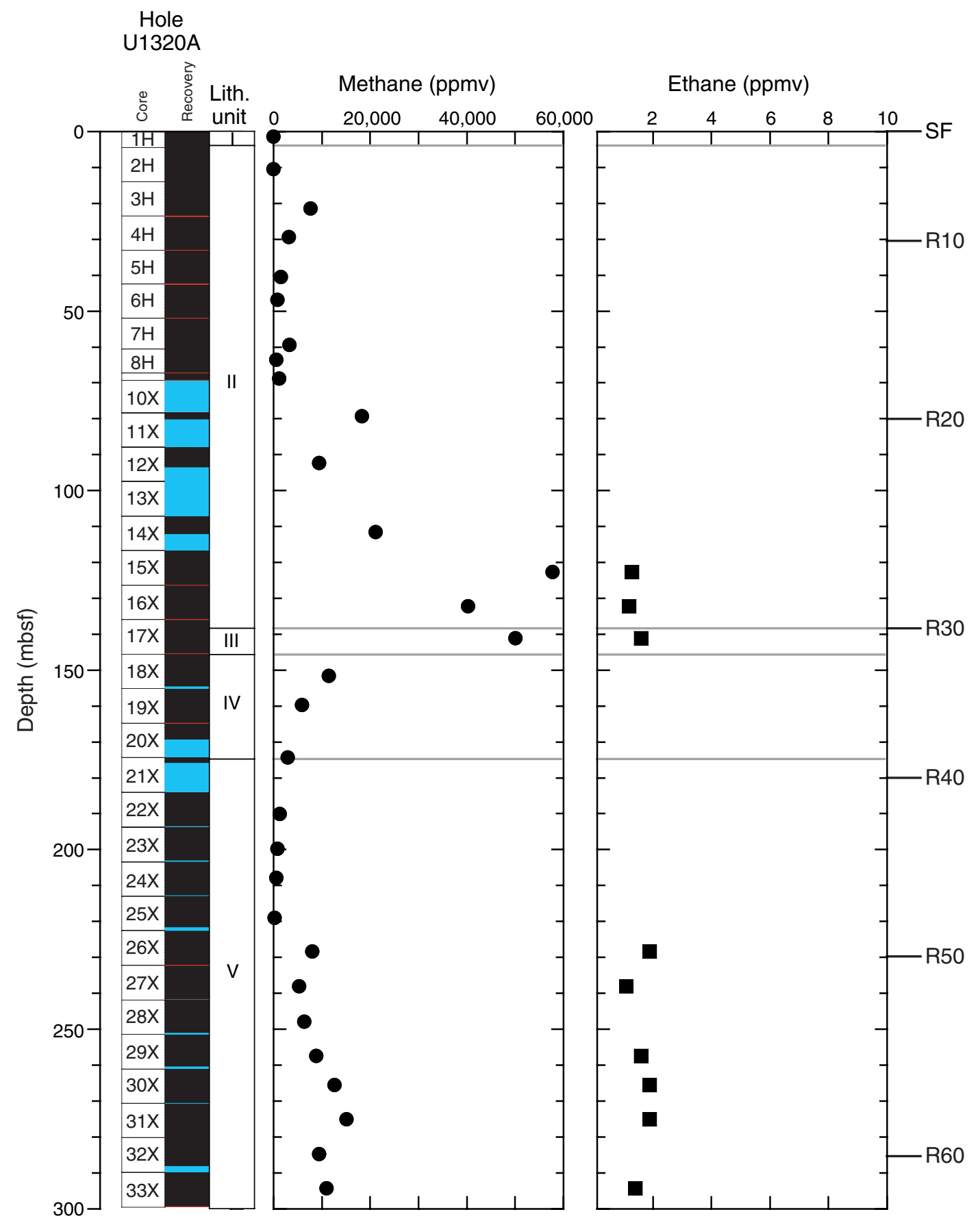


Figure F24. Methane and sulfate concentrations along with lithostratigraphic units and seismic reflectors (SF = seafloor).

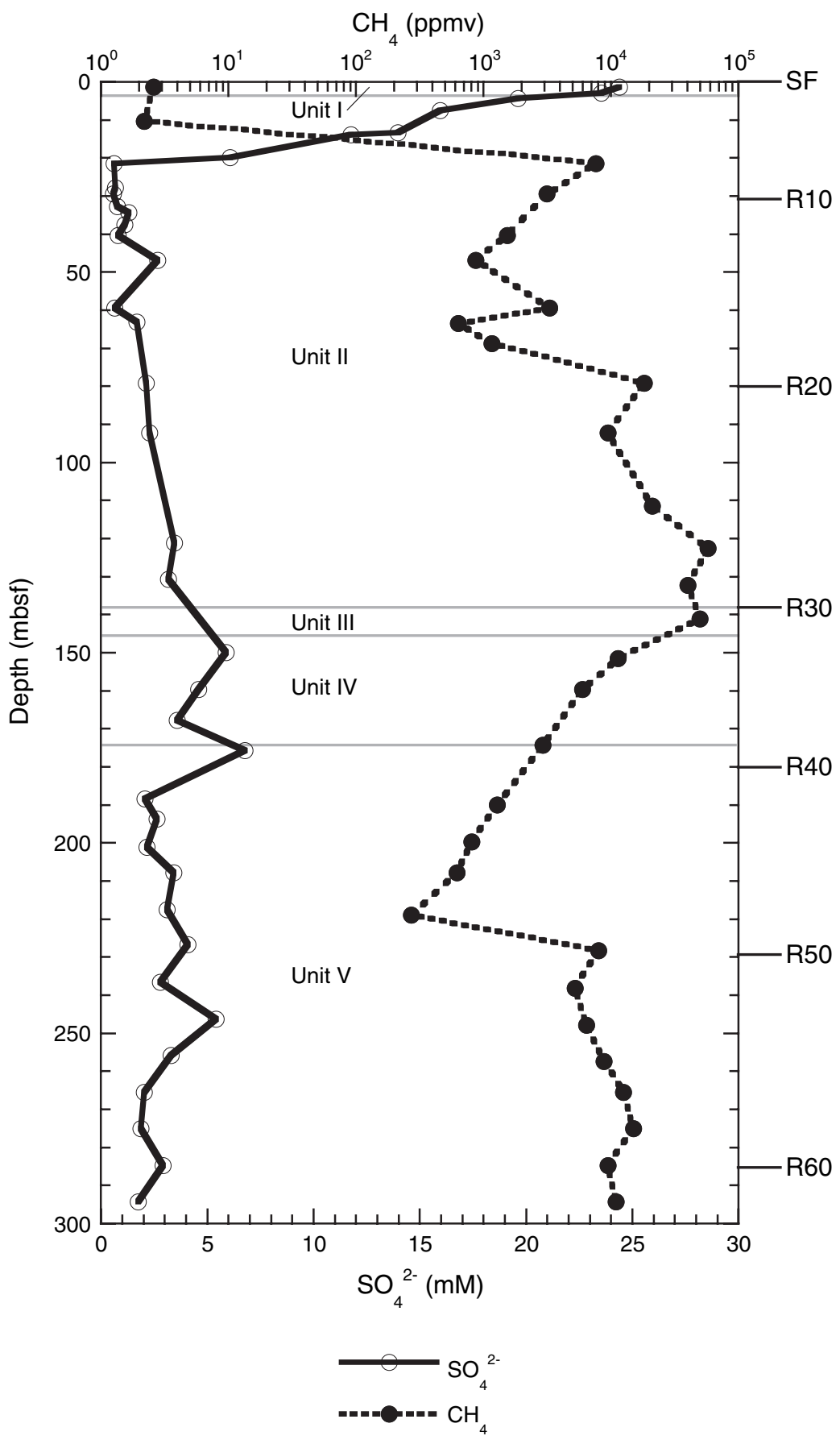


Figure F25. Vertical profile of cell density in Hole U1320A along with lithostratigraphic units and seismic reflectors $(\mathrm{SF}=$ seafloor$)$.

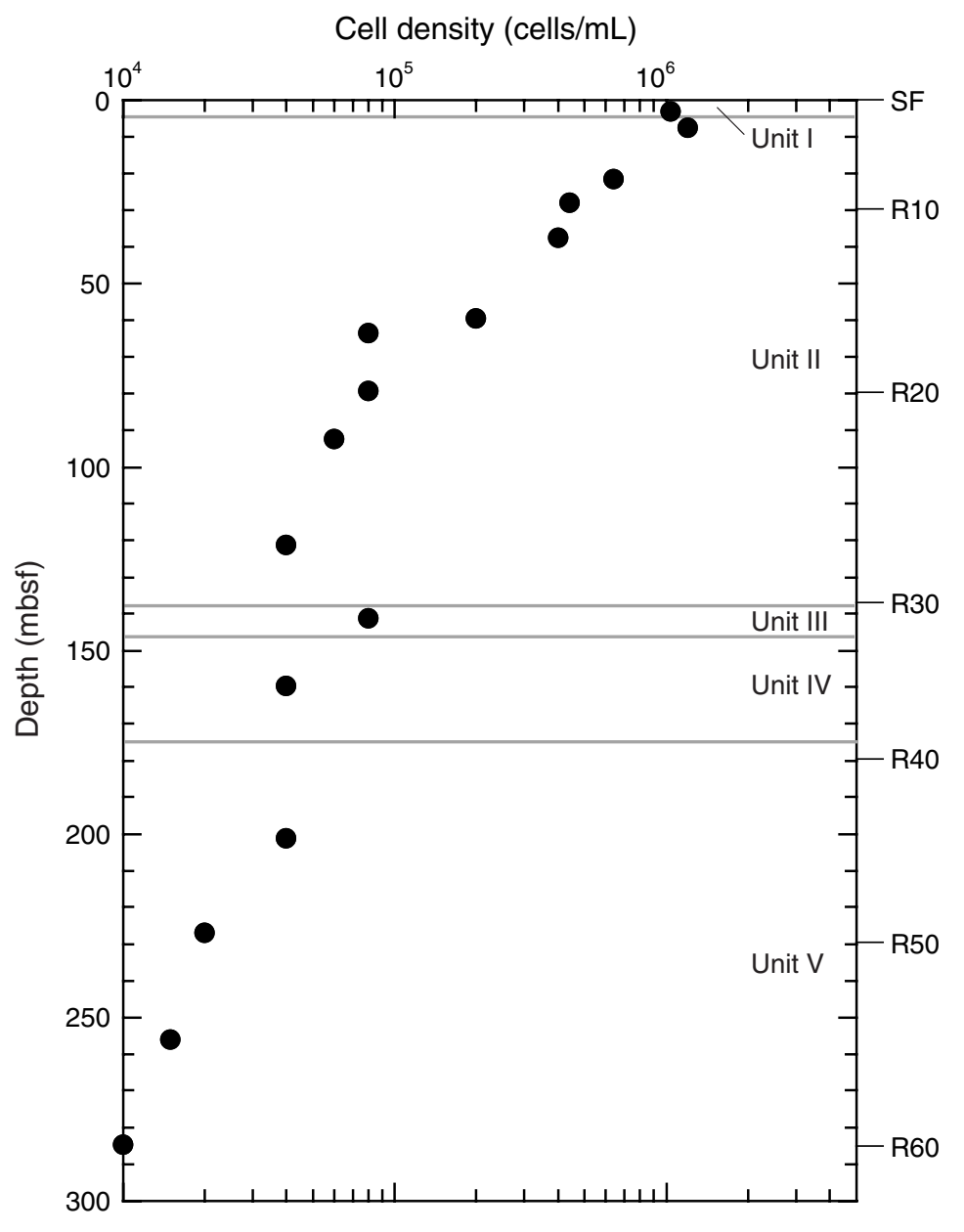


Figure F26. Porosity vs. vertical effective stress. The vertical hydrostatic effective stress $\left(\sigma_{\mathrm{vh}}{ }^{\prime}\right)$ profile is obtained assuming that hydrostatic conditions exist in the sediment column.

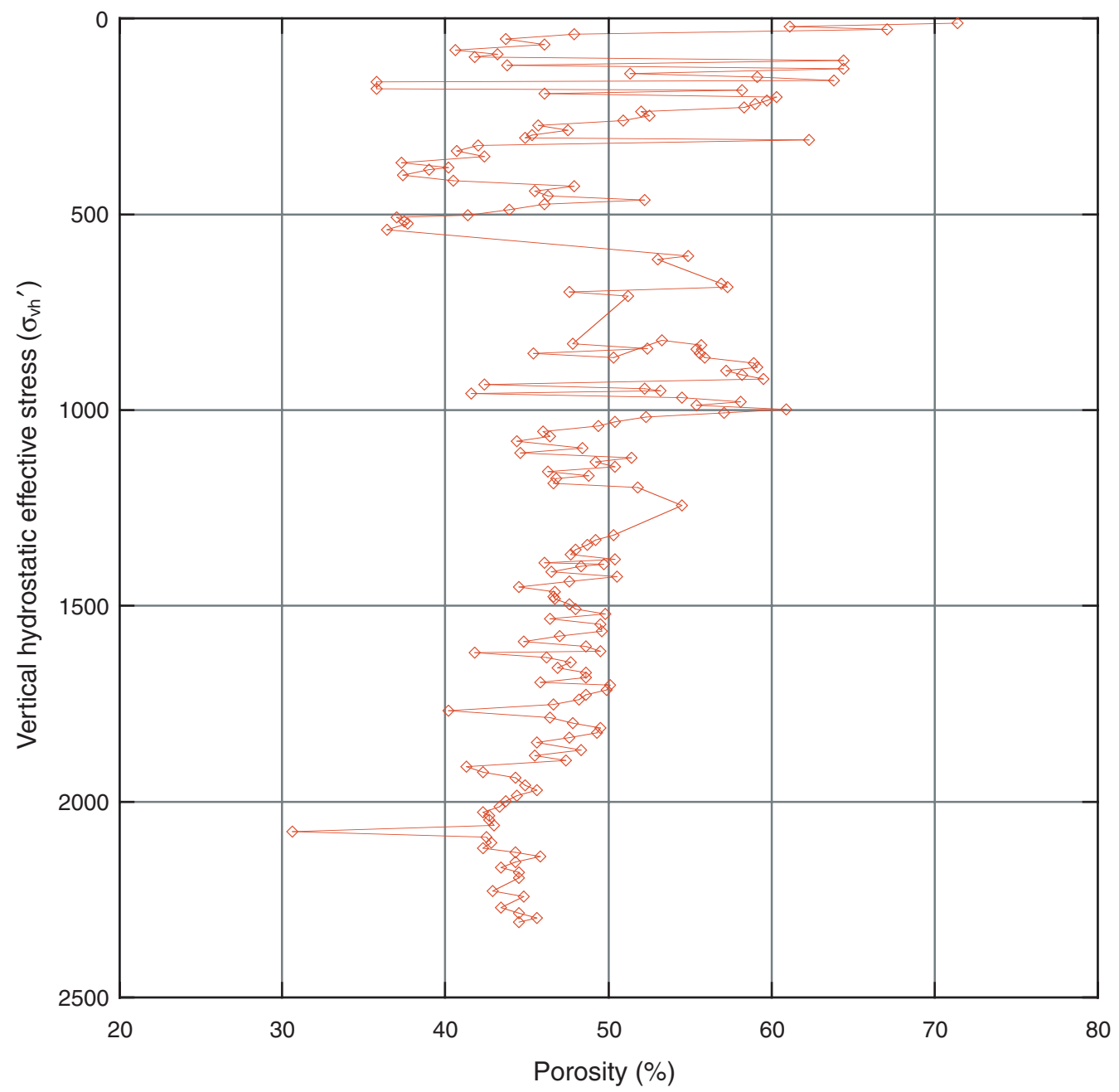


Figure F27. (A) Bulk density from moisture and density (MAD), multisensor track (MST), and measurement while drilling (MWD); (B) grain density; (C) porosity and $P$-wave velocity from the MST (uppermost $20 \mathrm{~m}$ only, probably due to voids and cracks), along with lithostratigraphic units and seismic reflectors $(\mathrm{SF}=$ seafloor$)$.

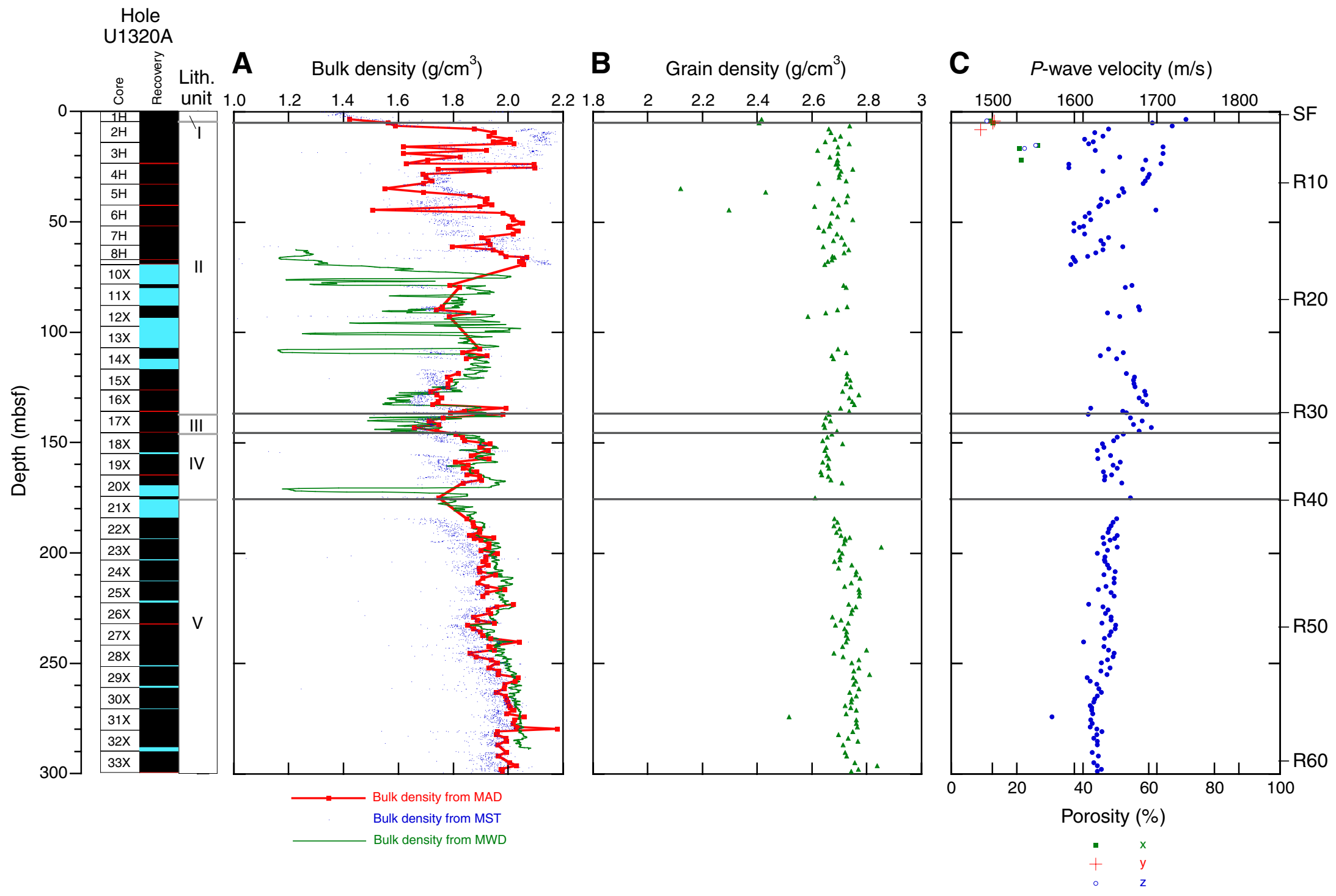


Figure F28. (A) Noncontact resistivity (from MST) and (B) resistivity from wireline logging (deep, medium, and shallow induction), along with lithostratigraphic units and seismic reflectors ( $\mathrm{SF}=$ seafloor).

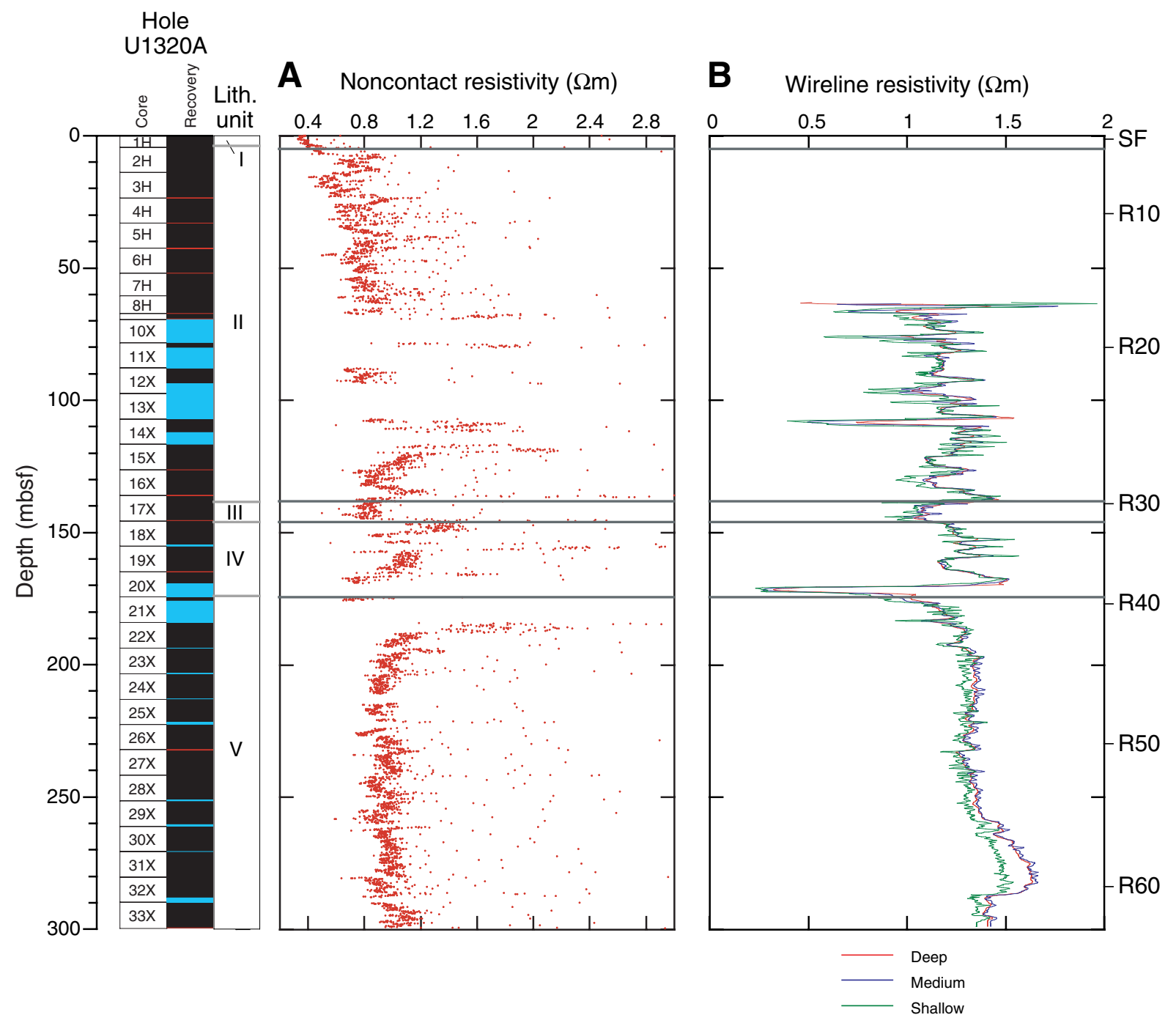


Figure F29. Magnetic susceptibility along with lithostratigraphic units and seismic reflectors $(\mathrm{SF}=$ seafloor $)$.

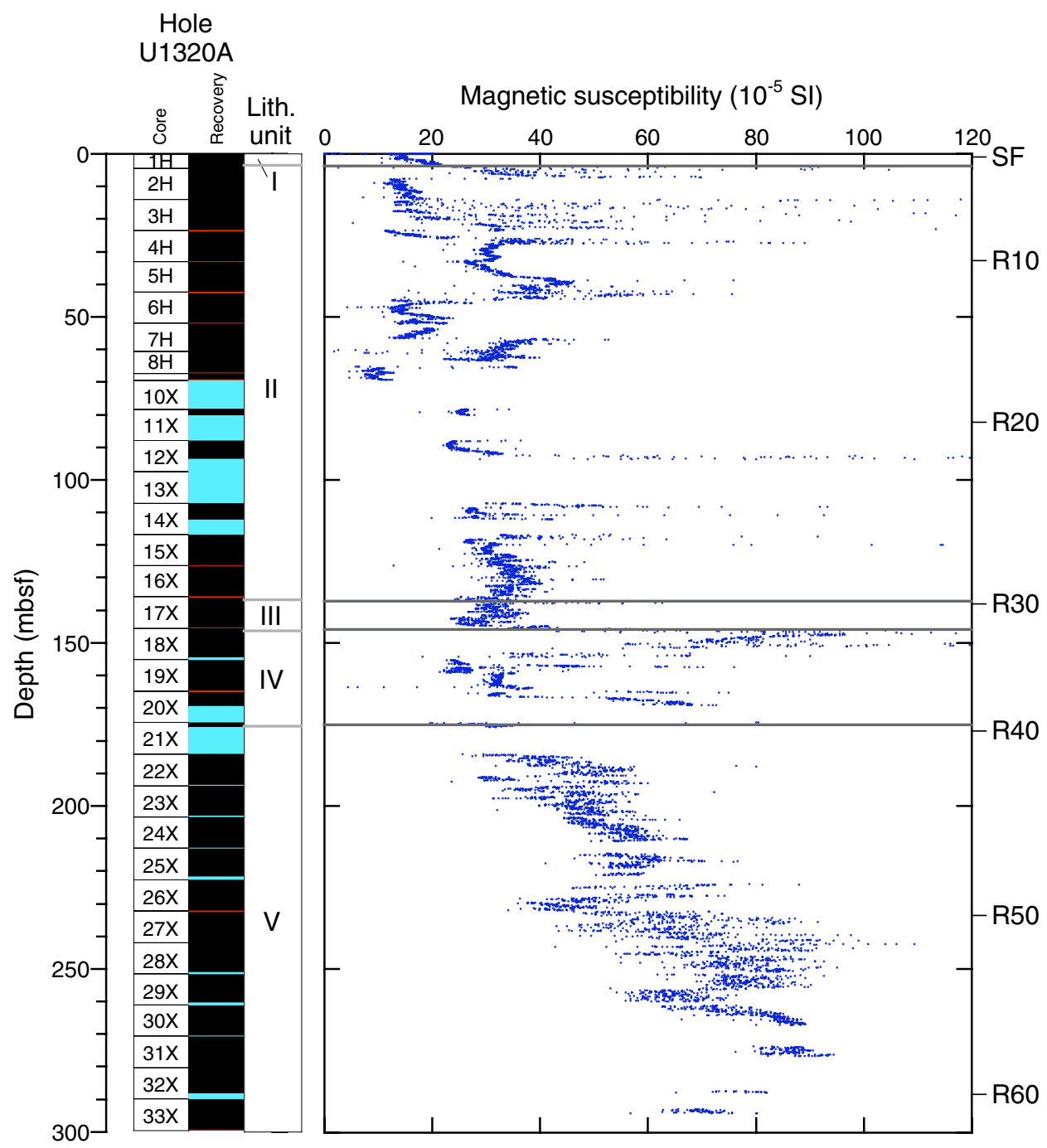


Figure F30. Thermal conductivity along with lithostratigraphic units and seismic reflectors (SF = seafloor).

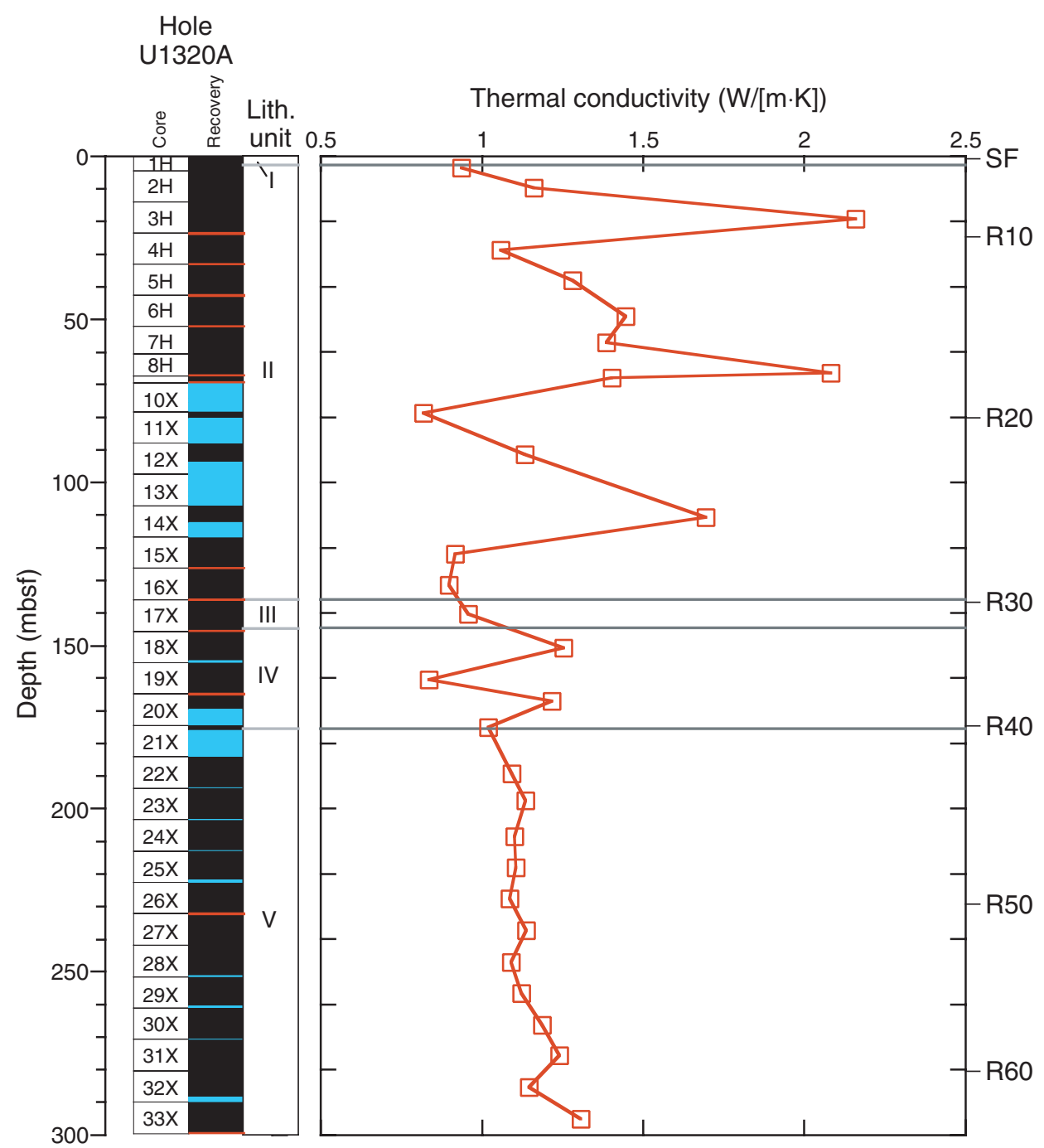


Figure F31. (A) Peak and residual undrained shear strength from vane shear tests, (B) peak undrained shear strengths measured using the vane and the pocket penetrometers, and (C) sensitivity (peak/residual undrained shear strength), along with lithostratigraphic units and seismic reflectors $(\mathrm{SF}=$ seafloor$)$.

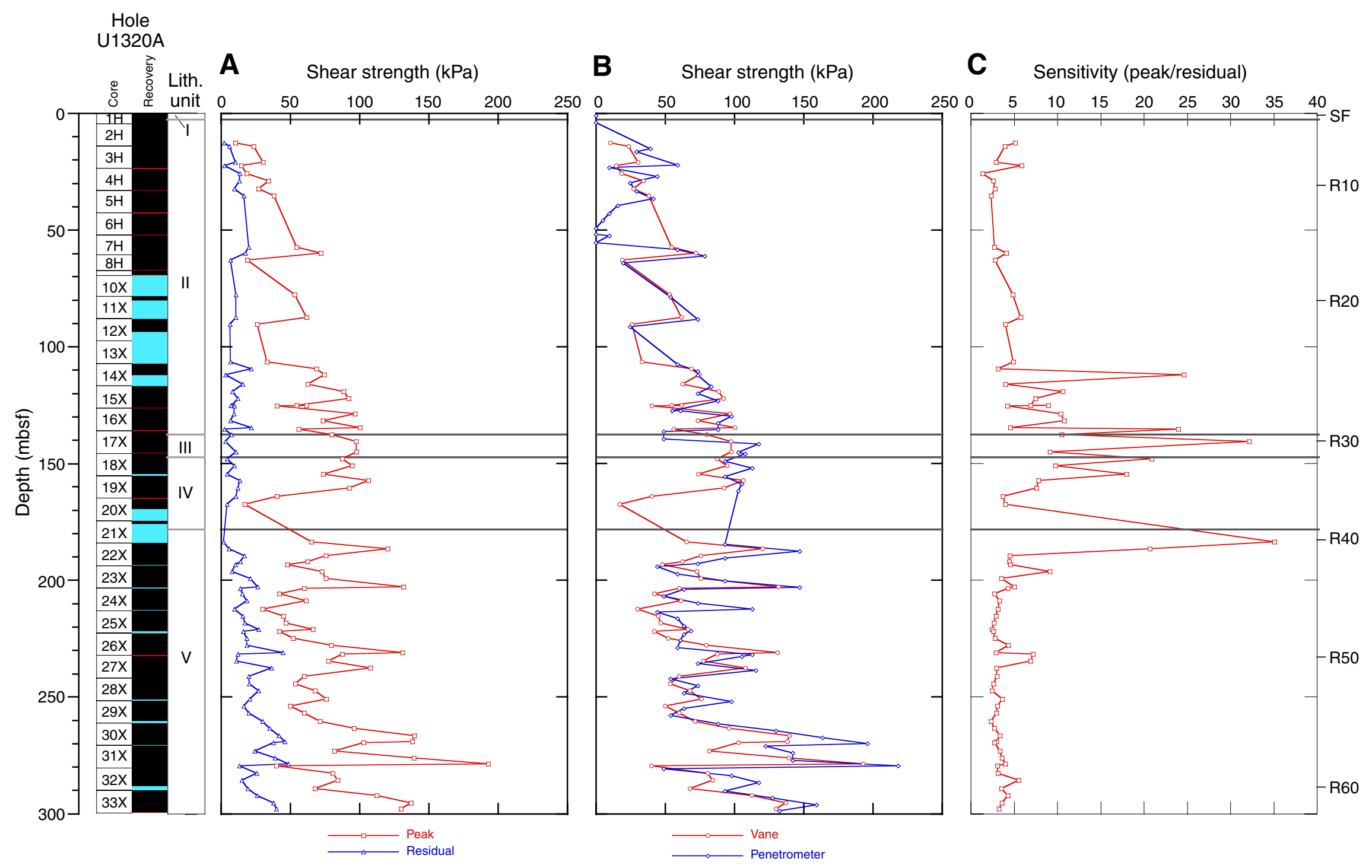


Figure F32. (A) Comparison between the undrained peak shear strength (red squares) and isolines representing constant peak shear strength to vertical hydrostatic effective stress $\left(\sigma_{\mathrm{vh}}{ }^{\prime}\right)$ ratios and $(\mathbf{B})$ vertical hydrostatic effective stress $\left(\sigma_{\mathrm{vh}}{ }^{\prime}\right)$ and total vertical stress $\left(\sigma_{\mathrm{v}}\right)$ based on hydrostatic conditions, along with lithostratigraphic units and seismic reflectors (SF = seafloor).

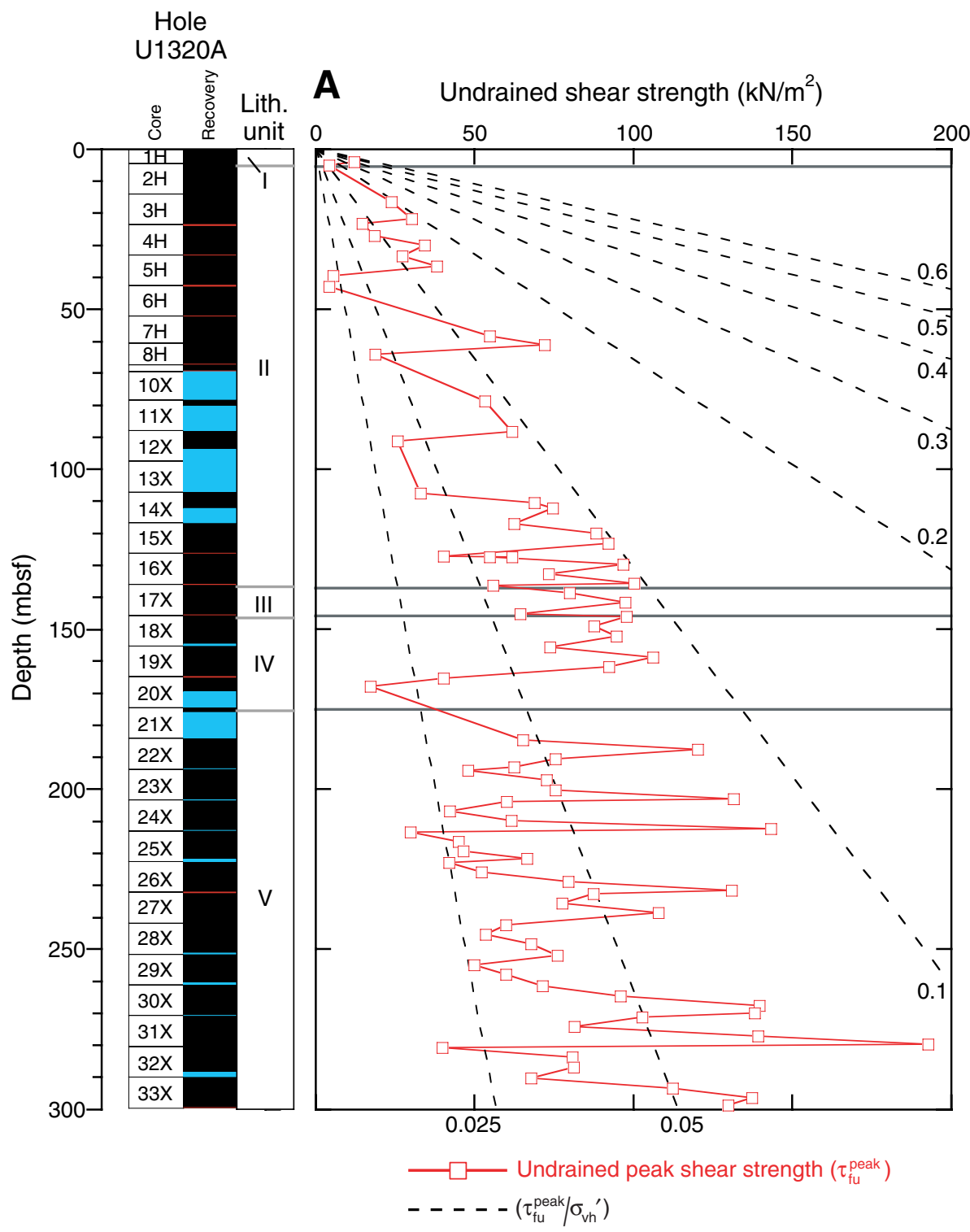

B
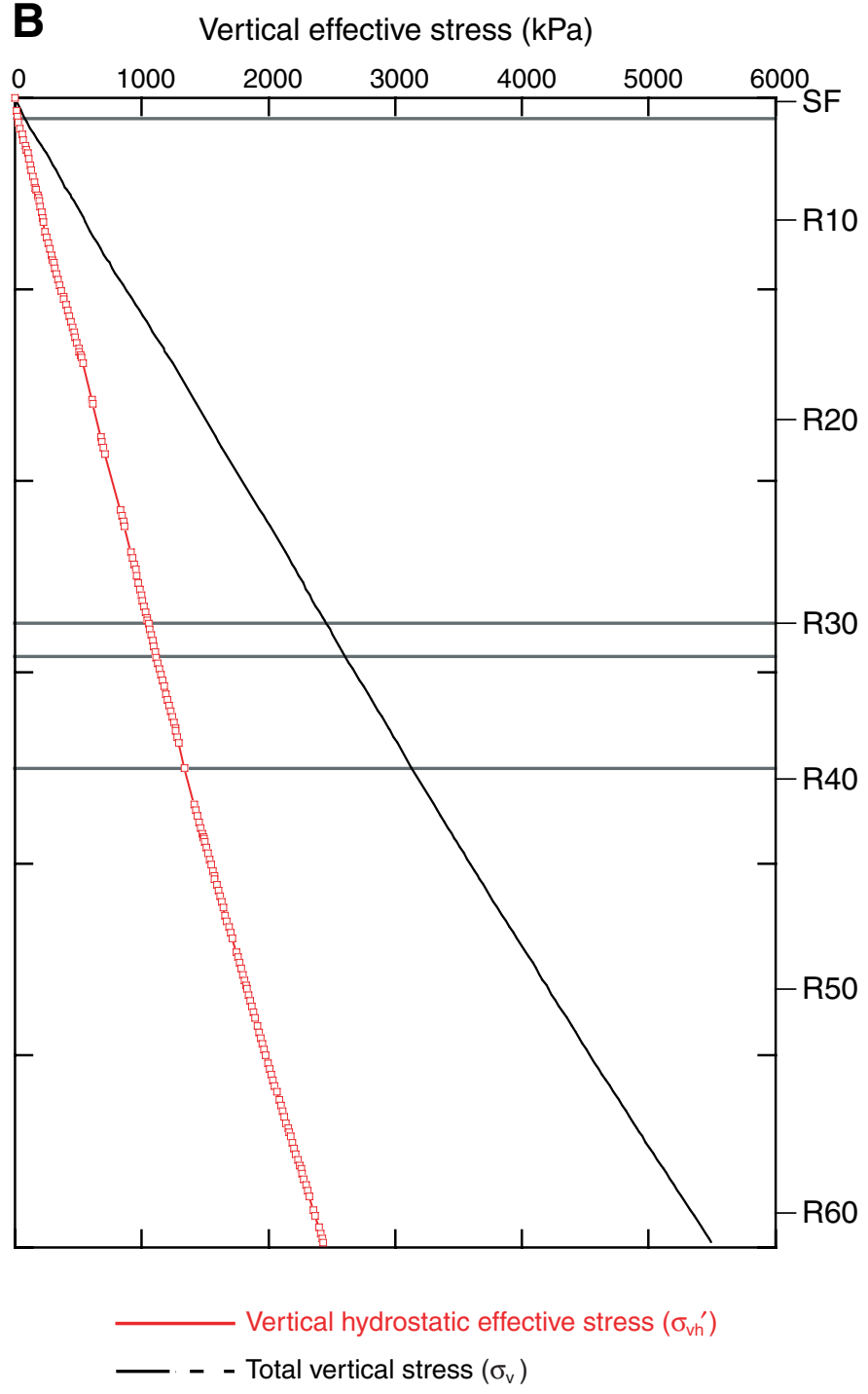
Figure F33. Lithostratigraphy and wireline logs showing Formation MicroScanner (FMS) caliper, total gamma ray, thorium, uranium, potassium, and electrical resistivity (deep, medium, and shallow) measurements. Seismic reflectors are correlated to logging data. $\mathrm{SF}=$ seafloor.

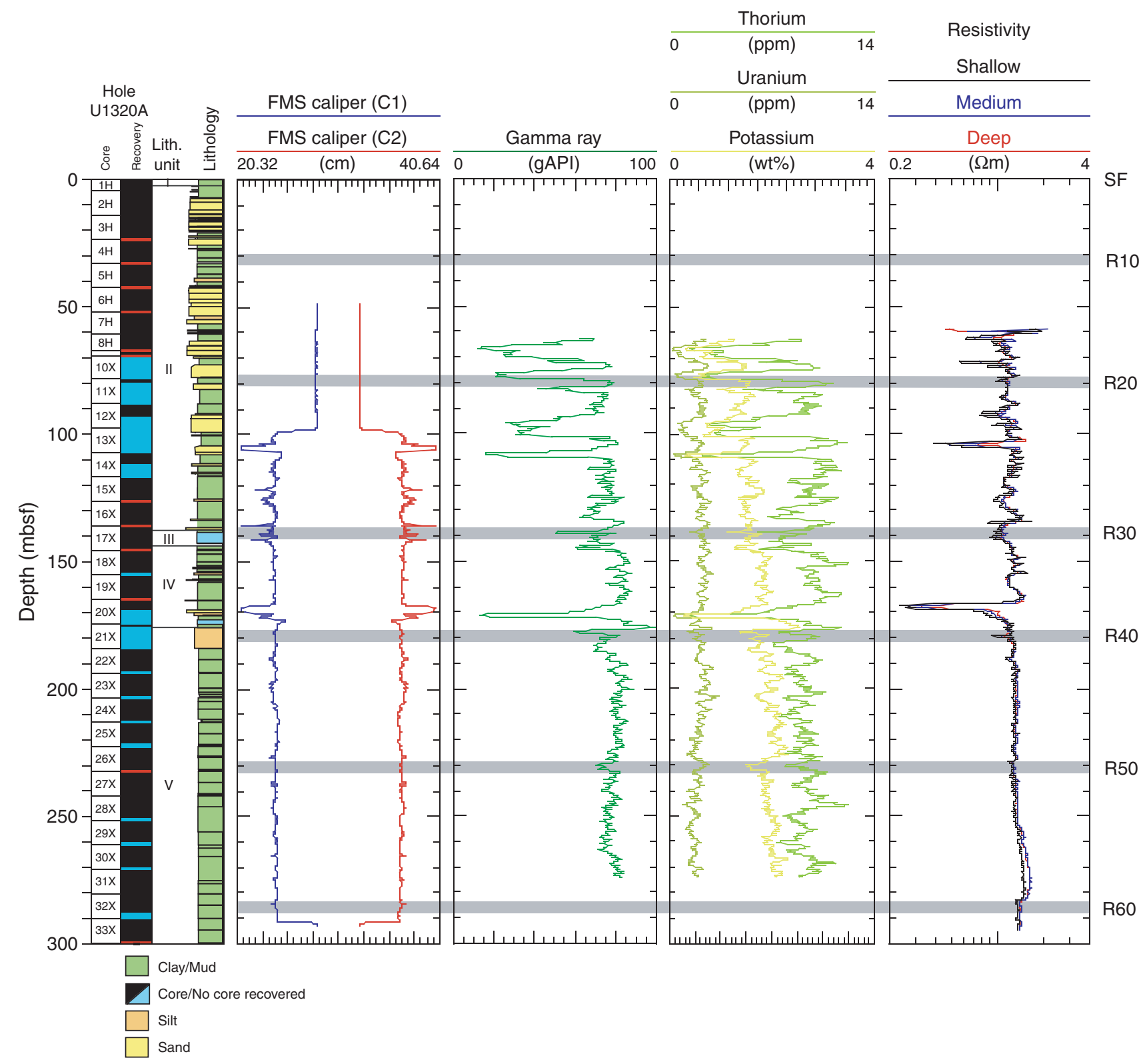


Figure F34. Lithostratigraphy and wireline logs showing Formation MicroScanner (FMS) caliper, density, compressional wave velocity, and porosity measurements. Shipboard density and porosity measurements (MAD) are also shown as discrete points. Seismic reflectors are correlated to logging data ( $\mathrm{SF}=$ seafloor). Velocities obtained with the WST check shot are denoted as red circles and plotted with the compressional wave velocity profile from the DSI.

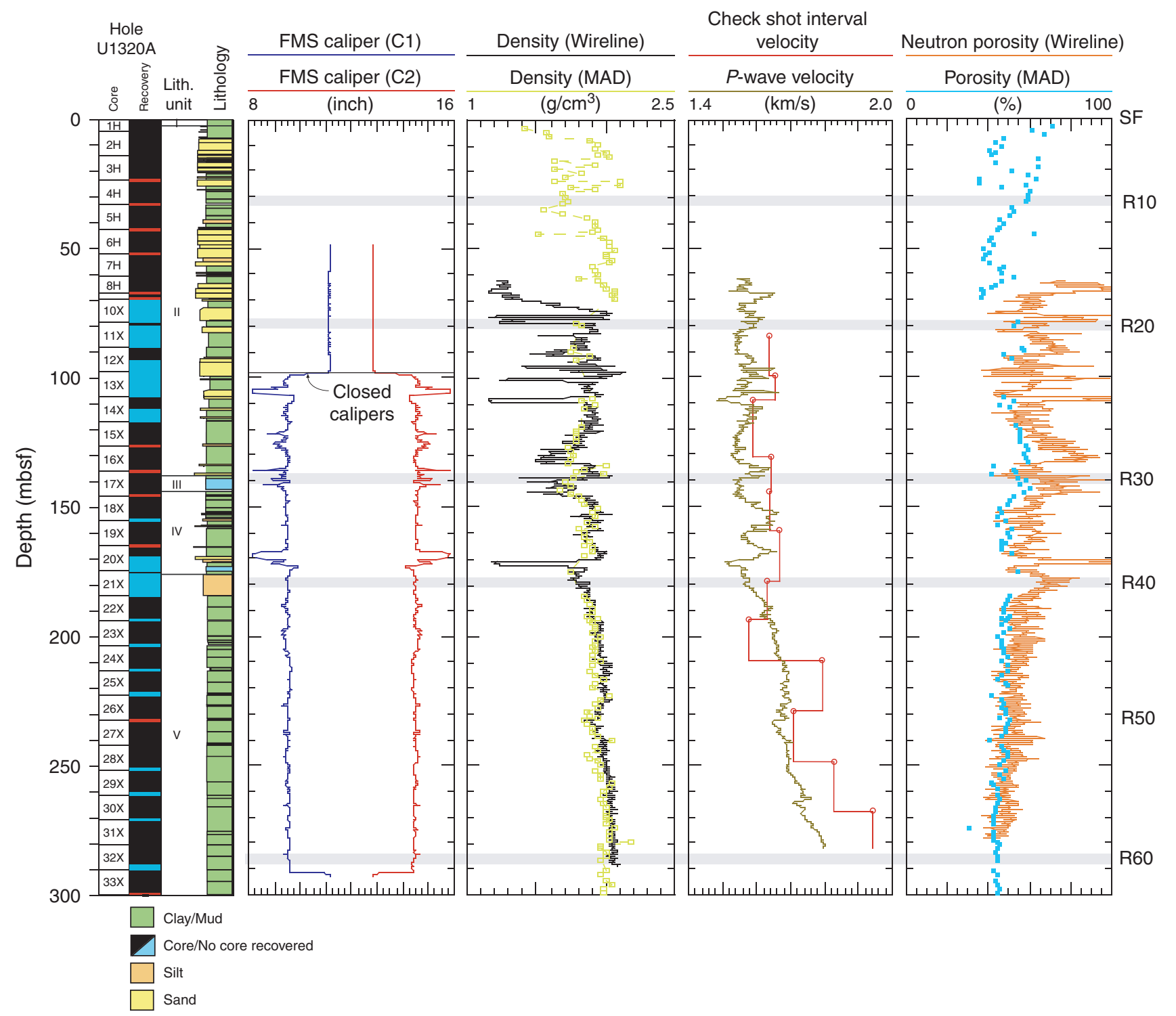


Figure F35. Processed FMS images from 124.5 to 139.5 mbsf showing high-angle deformation features, slump surfaces, borehole enlargements, and lithostratigraphic variations.

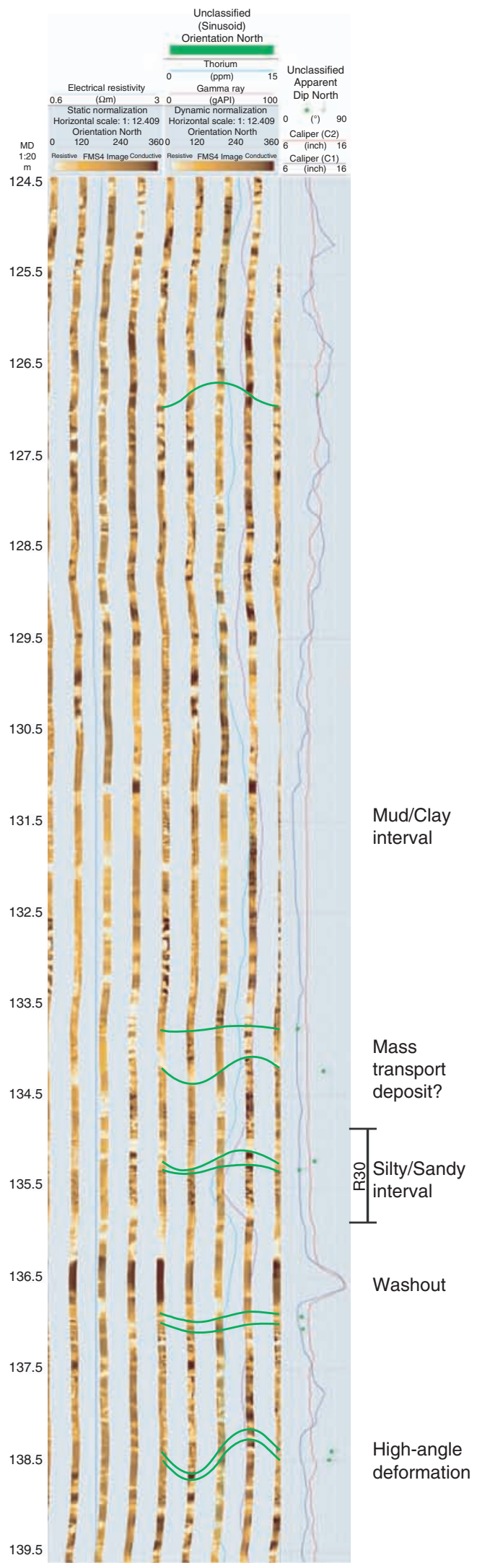


Figure F36. Velocity-depth plot of Hole U1320A showing wireline sonic and check shot interval velocities. Bulk density data from Hole U1320B are shown in column 3. A synthetic seismogram was constructed by convolving a $200 \mathrm{~Hz}$ minimum-phase Ricker wavelet with the reflection coefficient series based on LWD bulk density and a constant velocity $(1600 \mathrm{~m} / \mathrm{s})$. A seismic high-resolution trace (Hi-Res) is extracted from 2-D high-resolution multichannel seismic data at the location of Site U1320 (see also Figs. F43, F45; Table T13). SF = seafloor.

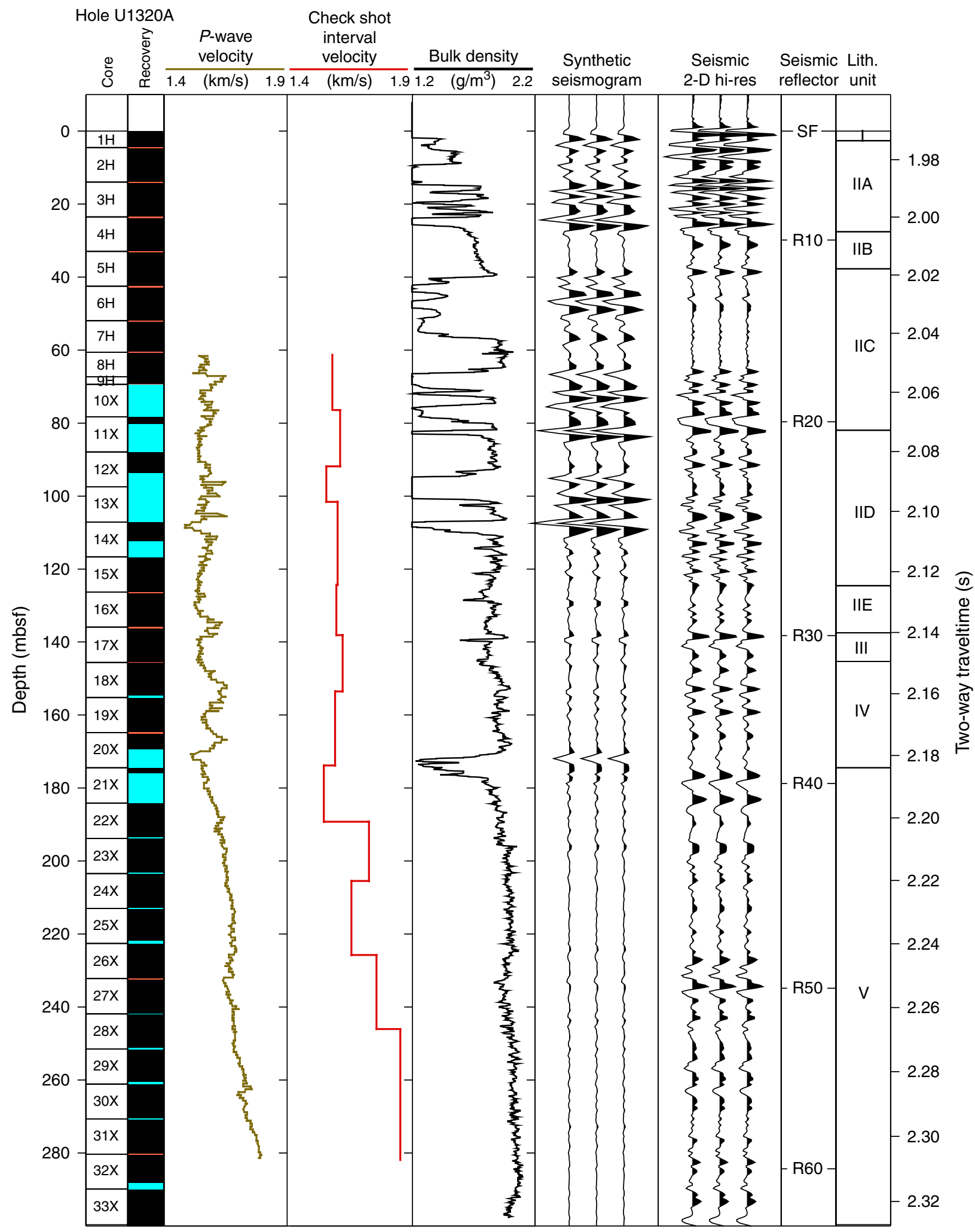


Figure F37. Data quality of curves for LWD/MWD measurements from Hole U1320B showing the rate of penetration, the density-derived caliper, and the density correction based on hole diameter.
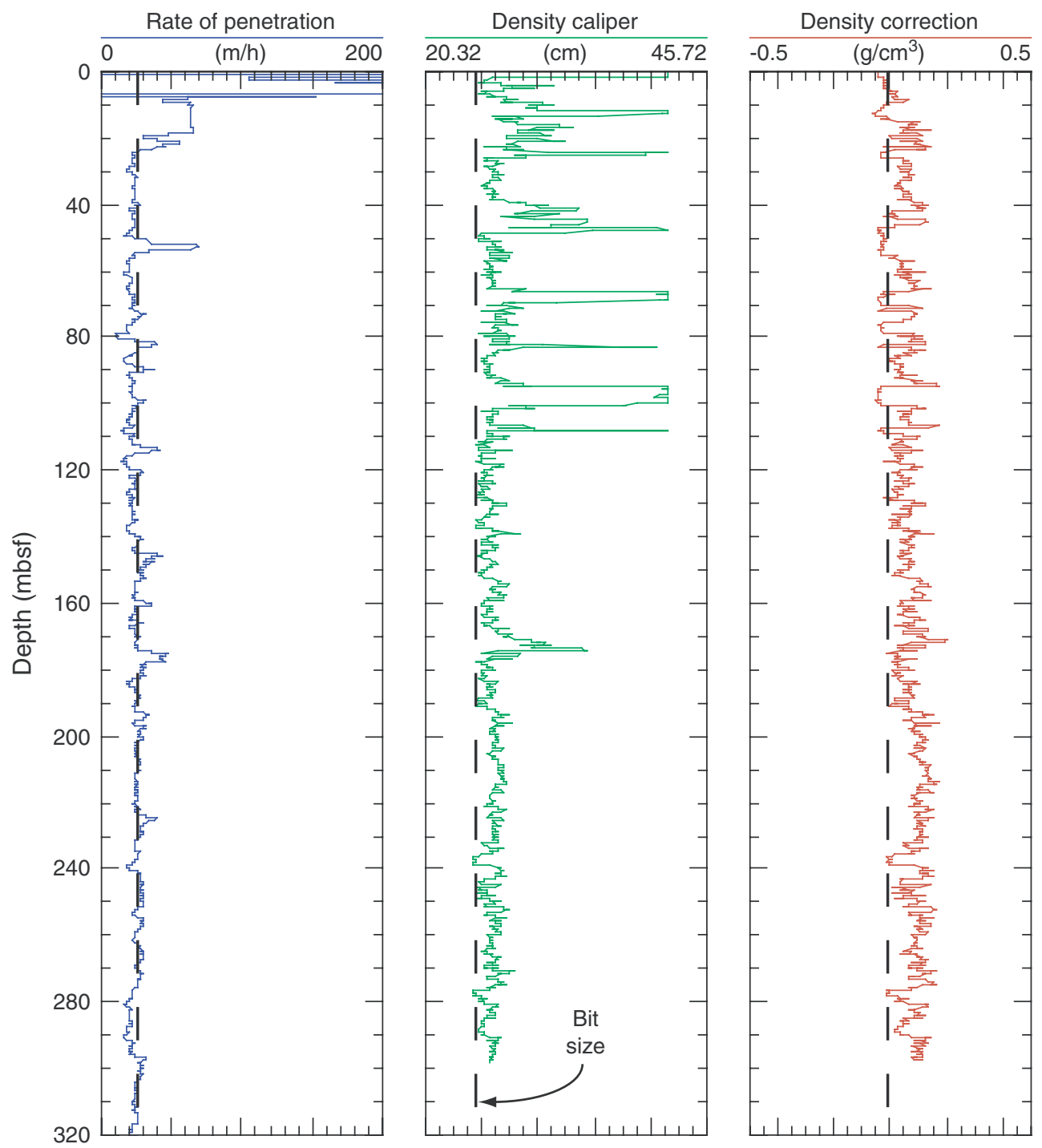
Figure F38. Annular pressure while drilling (APWD) monitoring of Hole U1320B. Near-linear increase of APWD is interpreted as stable borehole conditions without shallow-water flow problems. Variations in annular overpressure in excess of hydrostatic $\left(\mathrm{APWD}^{*}\right)$, equivalent circulating density referenced to seafloor $\left(\mathrm{ECD}_{\mathrm{rs}},\right)$ and caliper measurements are interpreted as loose material filling the borehole annulus, especially when encountering sand units. SF = seafloor.

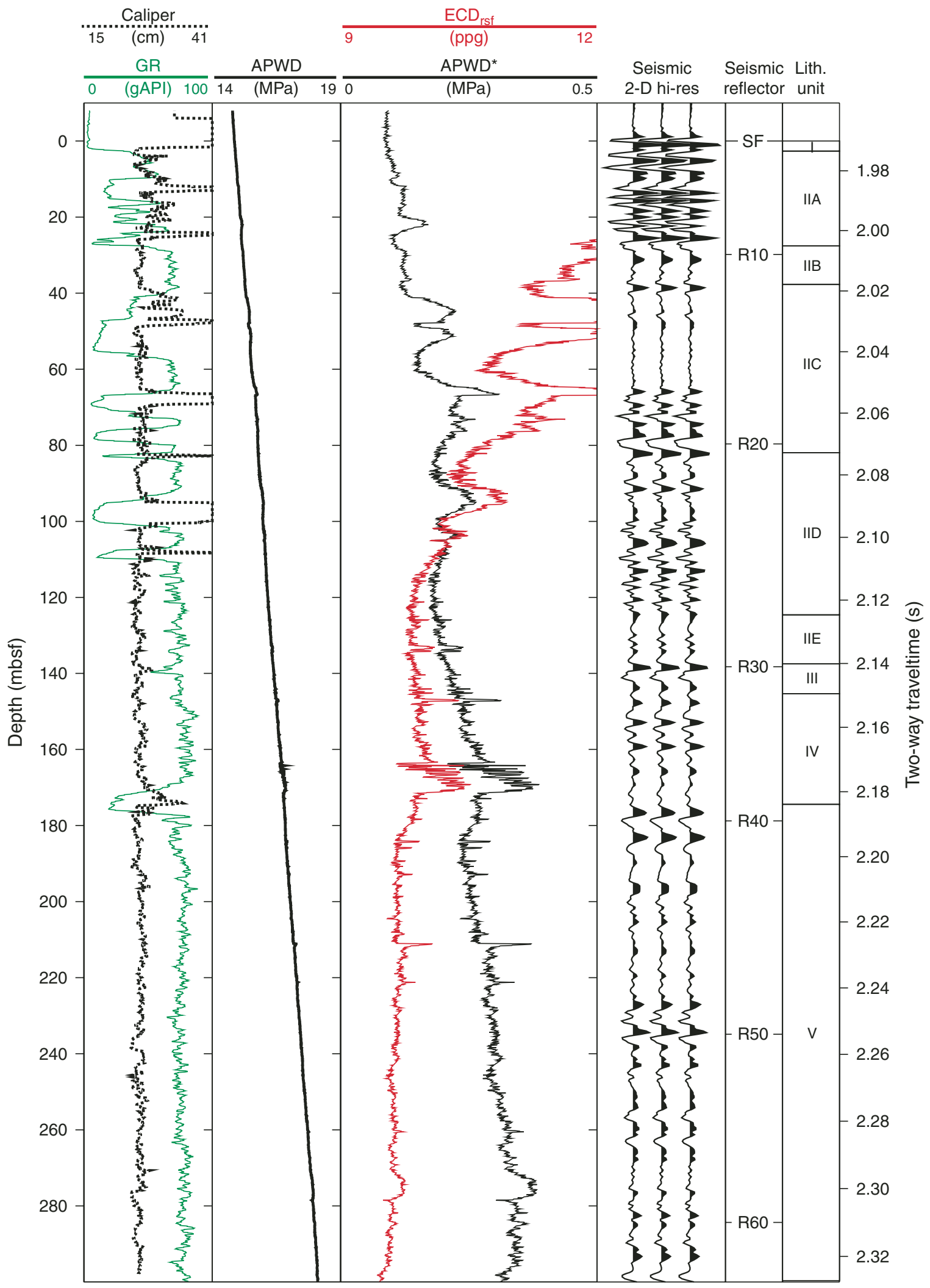


Figure F39. LWD logs recorded in Hole U1320B. Density caliper, photoelectric factor (PEF), and neutron porosity were recorded with the VDN tool, whereas gamma ray and resistivity measurements were obtained with the GVR tool. Superimposed on the PEF log is a five-point sliding window curve. Laboratory discrete density and porosity measurements (MAD) are compared to the logging results. SF $=$ seafloor.

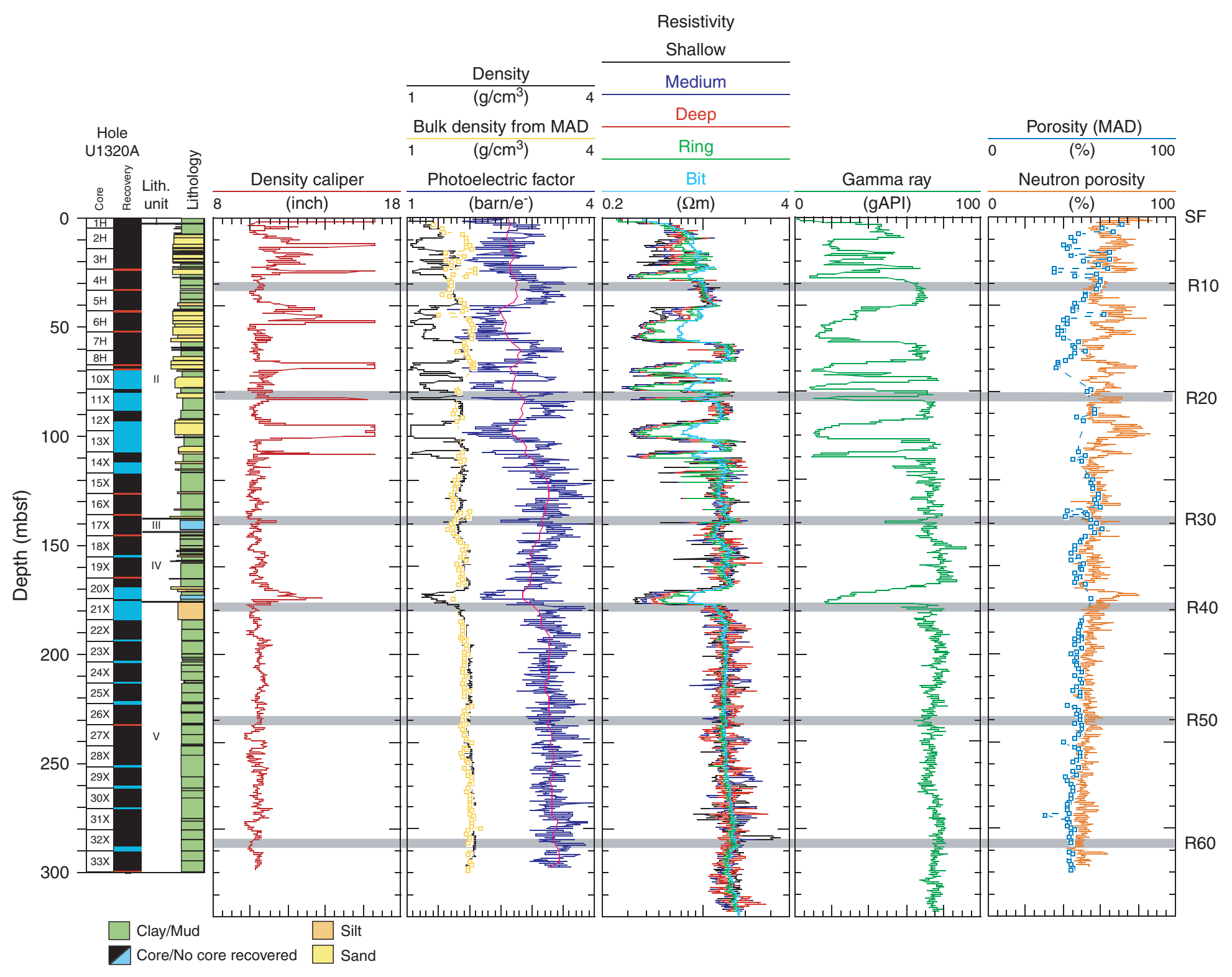


Figure F40. Resistivity-at-the-bit (RAB) GeoVision resistivity (GVR) deep resistivity image of Hole U1320B showing thin layers within lithostratigraphic Subunit IIE and the contact between this unit and lithostratigraphic Unit III. The top of lithostratigraphic Unit III correlates with seismic Reflector R30.

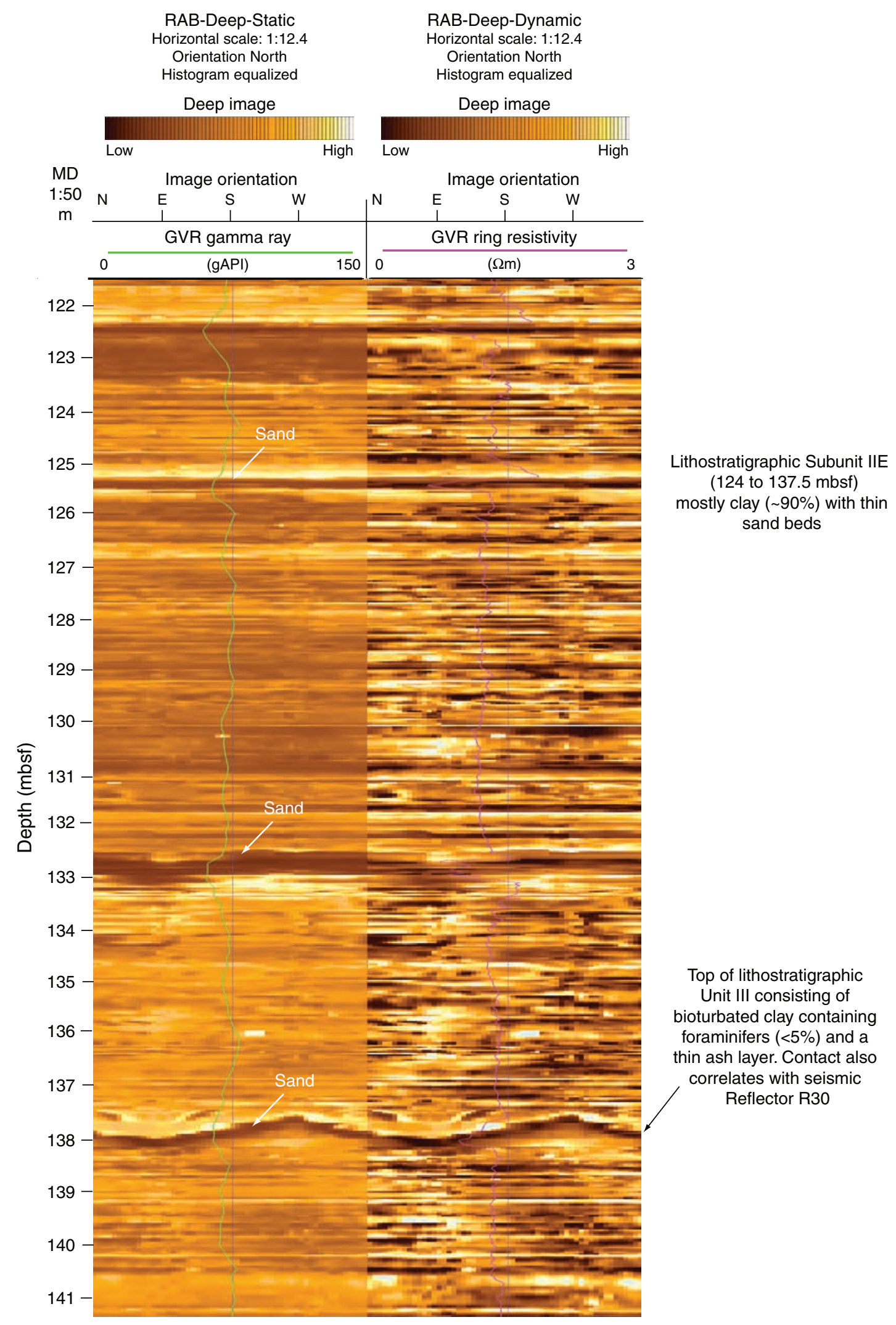


Figure F41. Resistivity-at-the-bit (RAB) GeoVision resistivity (GVR) deep resistivity image of Hole U1320B showing steeply dipping beds within clay-rich lithostratigraphic Unit V. Dip is marked as a number. Azimuth is graphically represented with north to the top of the page.

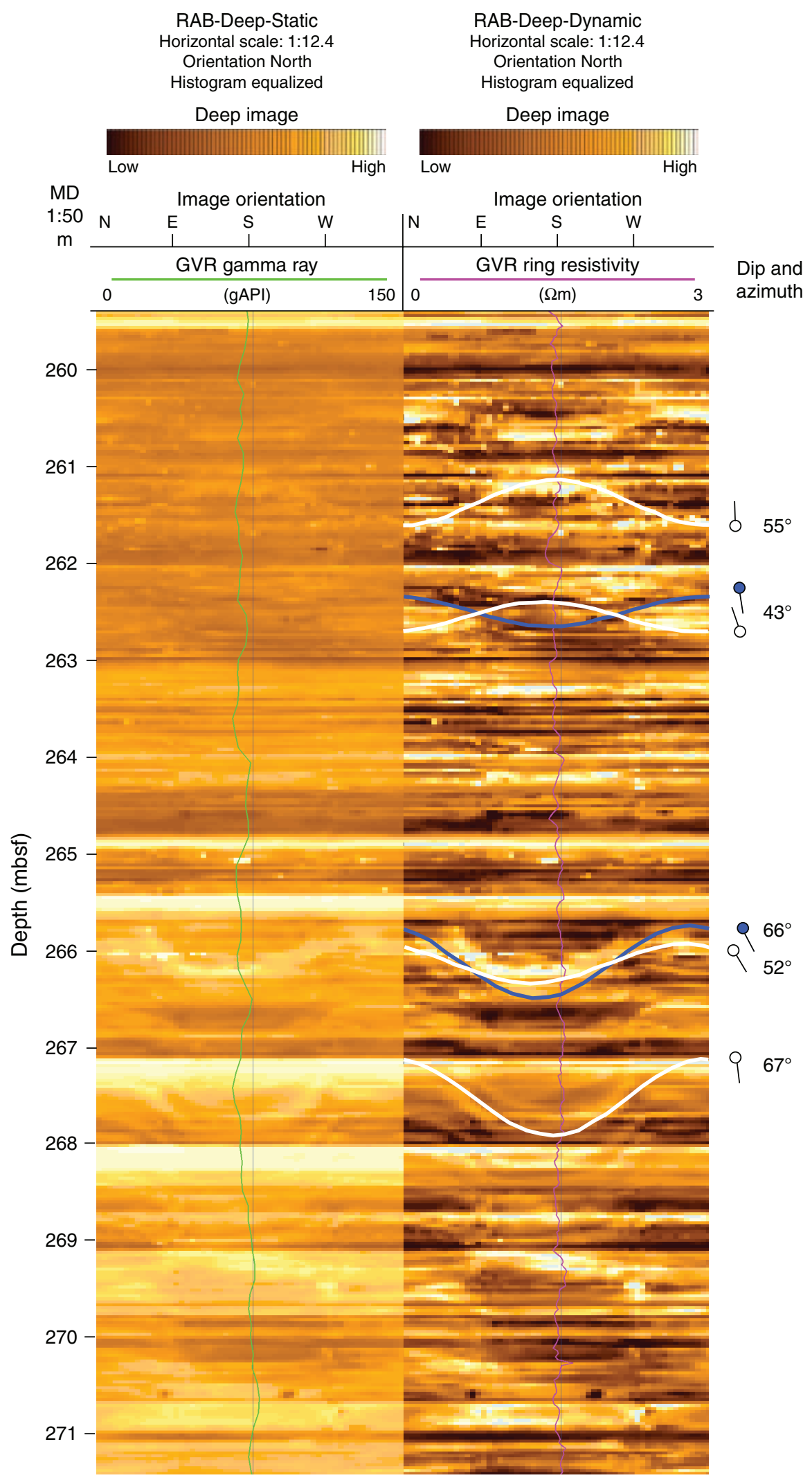


Figure F42. Resistivity-at-the-bit (RAB) GeoVision resistivity (GVR) deep resistivity image of Hole U1320B showing borehole breakouts trending east-west and suggesting a north-south maximum stress direction.

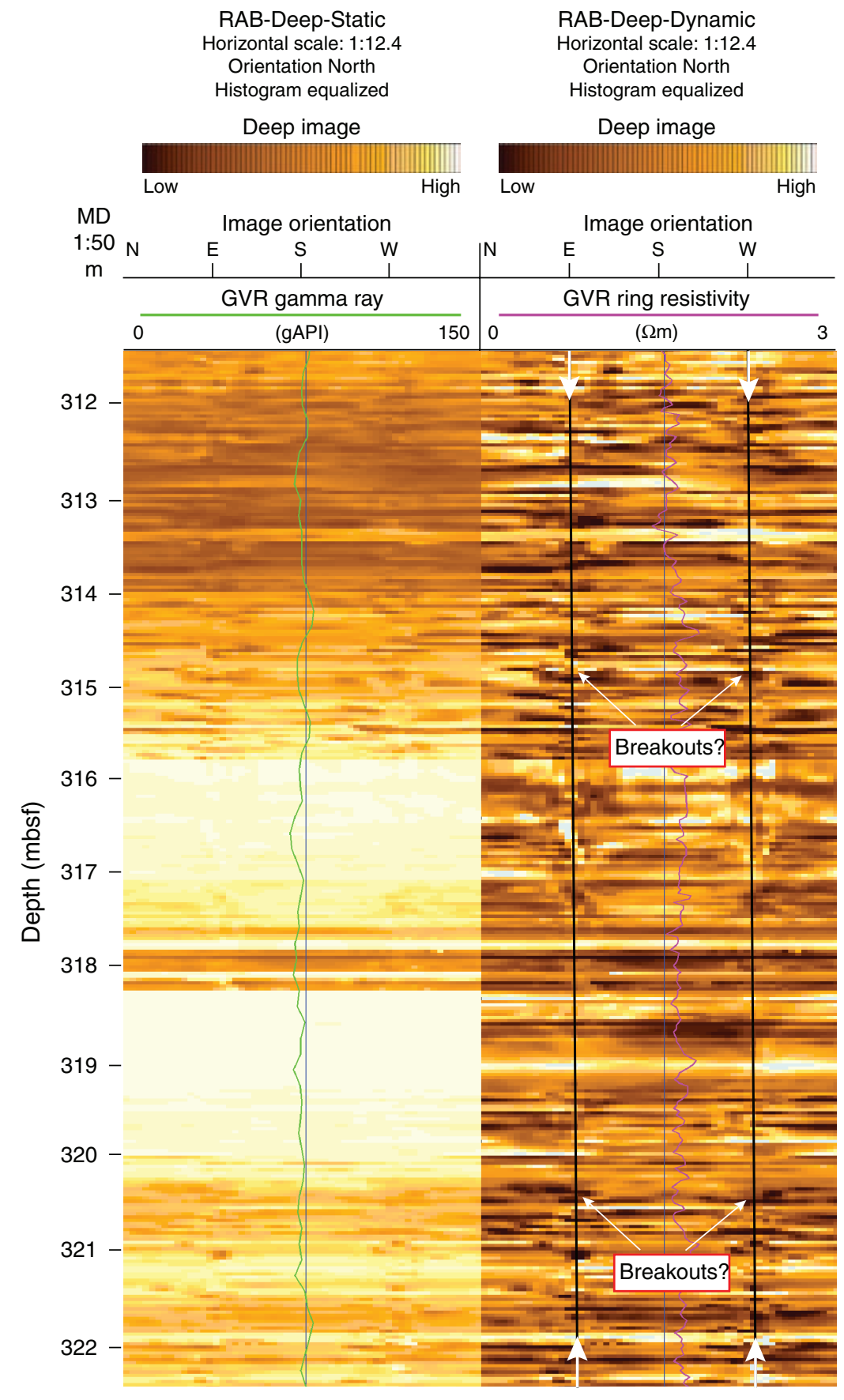


Figure F43. Traveltime-depth conversion curves obtained from the Hole U1320A check shot survey and vertical seismic profile (VSP), and predrill time-depth prediction (see Equation E1 in "Background and objectives" in the "Site U1319" chapter). All measured data are referenced to the seafloor assuming a velocity of $1490 \mathrm{~m} / \mathrm{s}$ through the water column. The predicted two-way travel times are greater the check shots above $200 \mathrm{mbsf}$.

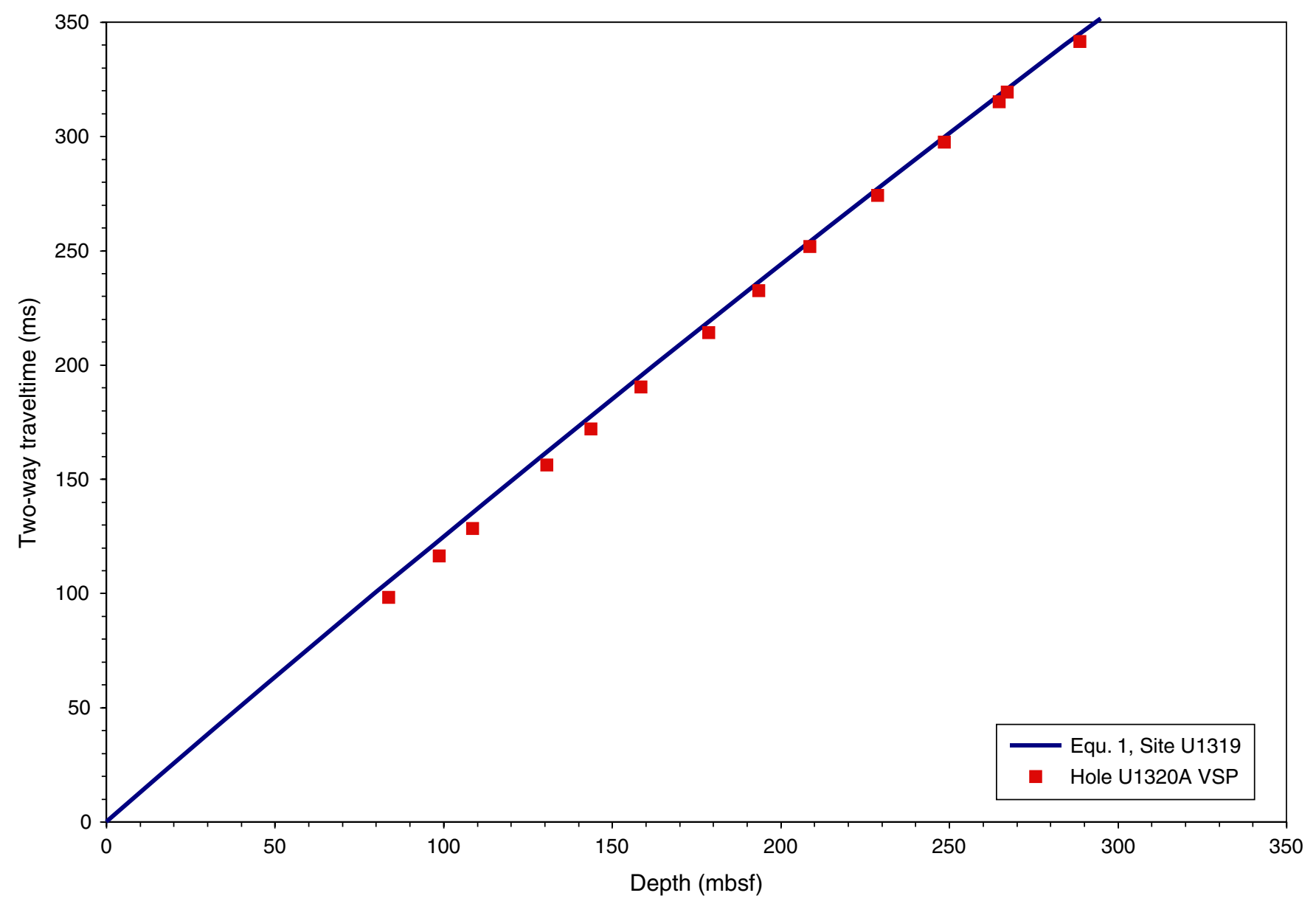


Figure F44. Correlation between wireline and logging-while-drilling (LWD) logs from Site U1320. Wireline data were obtained in Hole U1320A and LWD in Hole U1320B, $20 \mathrm{~m}$ apart. Regional seismic reflectors $(\mathrm{SF}=$ seafloor) and lithostratigraphic units are also correlated to the logs.

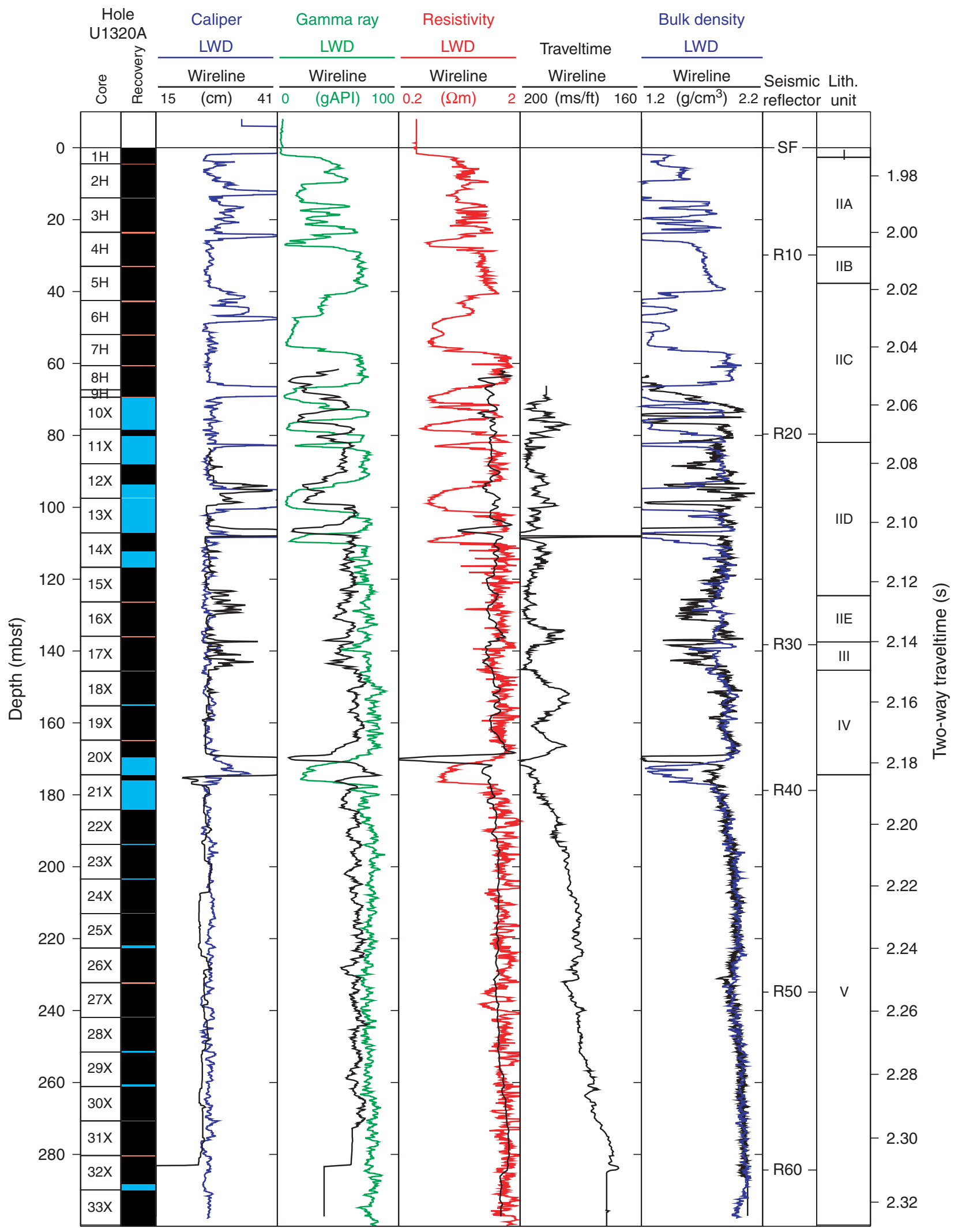


Figure F45. Core-log-seismic correlation for Site U1320. Synthetic seismogram was constructed by convolving a $200 \mathrm{~Hz}$ minimum-phase Ricker wavelet with the reflection coefficient series based on LWD bulk density and a constant velocity $(1600 \mathrm{~m} / \mathrm{s})$. A seismic high-resolution trace (Hi-Res) is extracted from 2-D high-resolution multichannel seismic data at the location of Site U1320. GR = gamma ray. SF = seafloor.

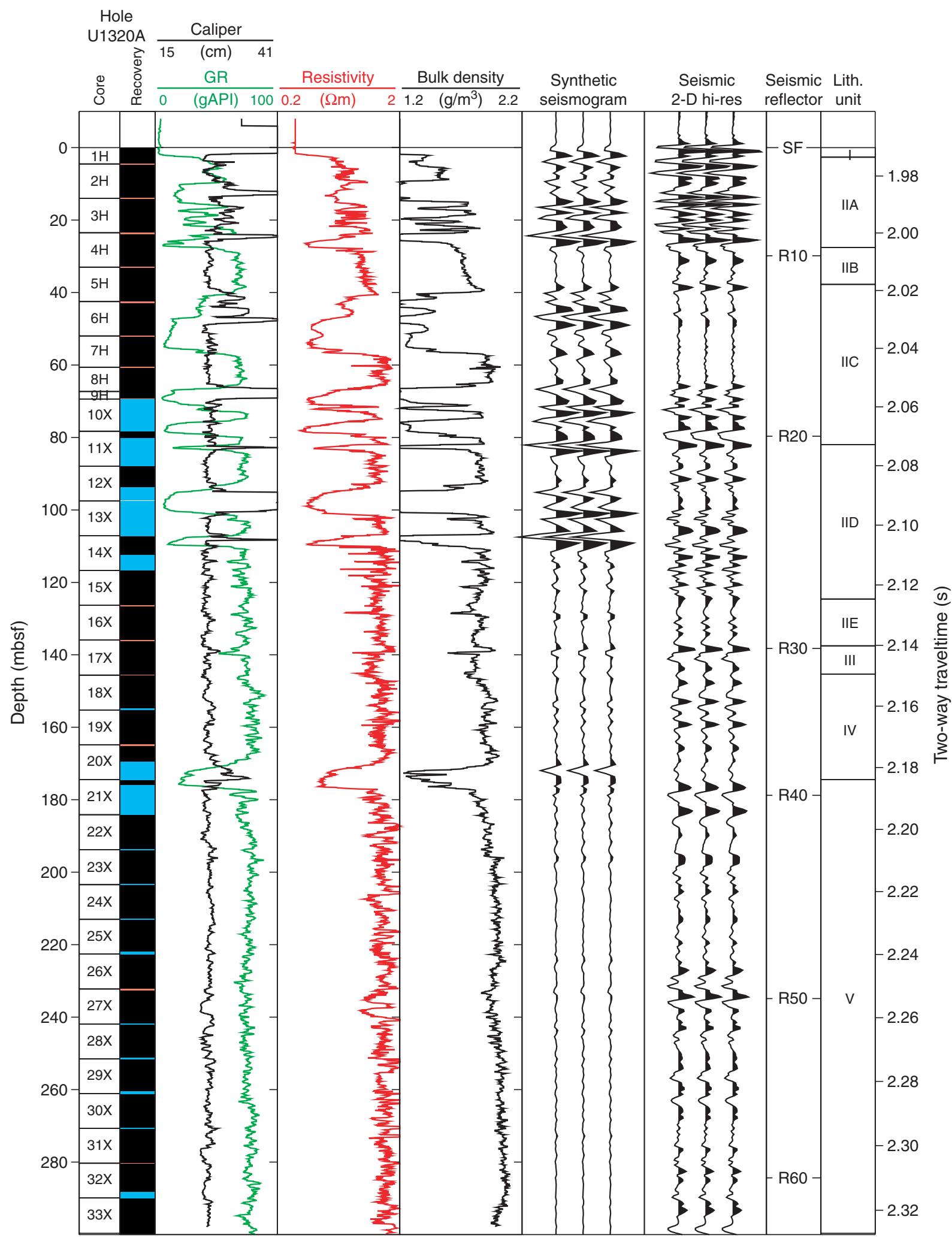


Figure F46. Fluid pressure and temperature measured by temperature/dual pressure probe (T2P) Deployment 3. The probe measurements were made in the top of the sediments recovered in Core 308-U1320A-16X. CDT = central daylight time. A time series of deployment events is provided in Table T15. See "Downhole" in "Supplementary material" for raw data.

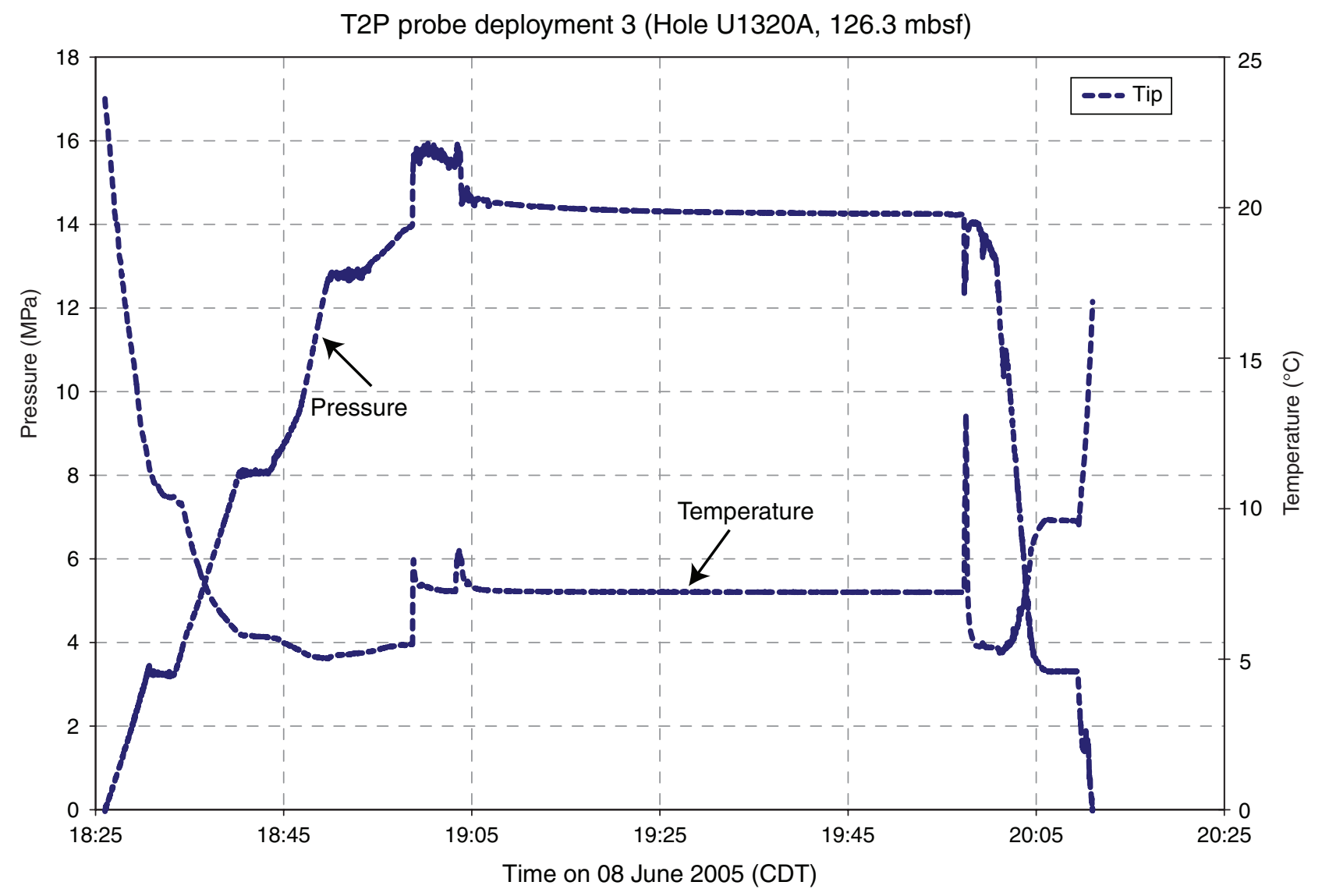


Figure F47. Fluid pressure and temperature measured by temperature/dual pressure probe (T2P) Deployment 4. The probe measurements were made in the top of the sediments recovered in Core 308-U1320A-25X. CDT = central daylight time. Table T16 provides the time-event log for this deployment. See "Downhole" in "Supplementary material" for raw data.

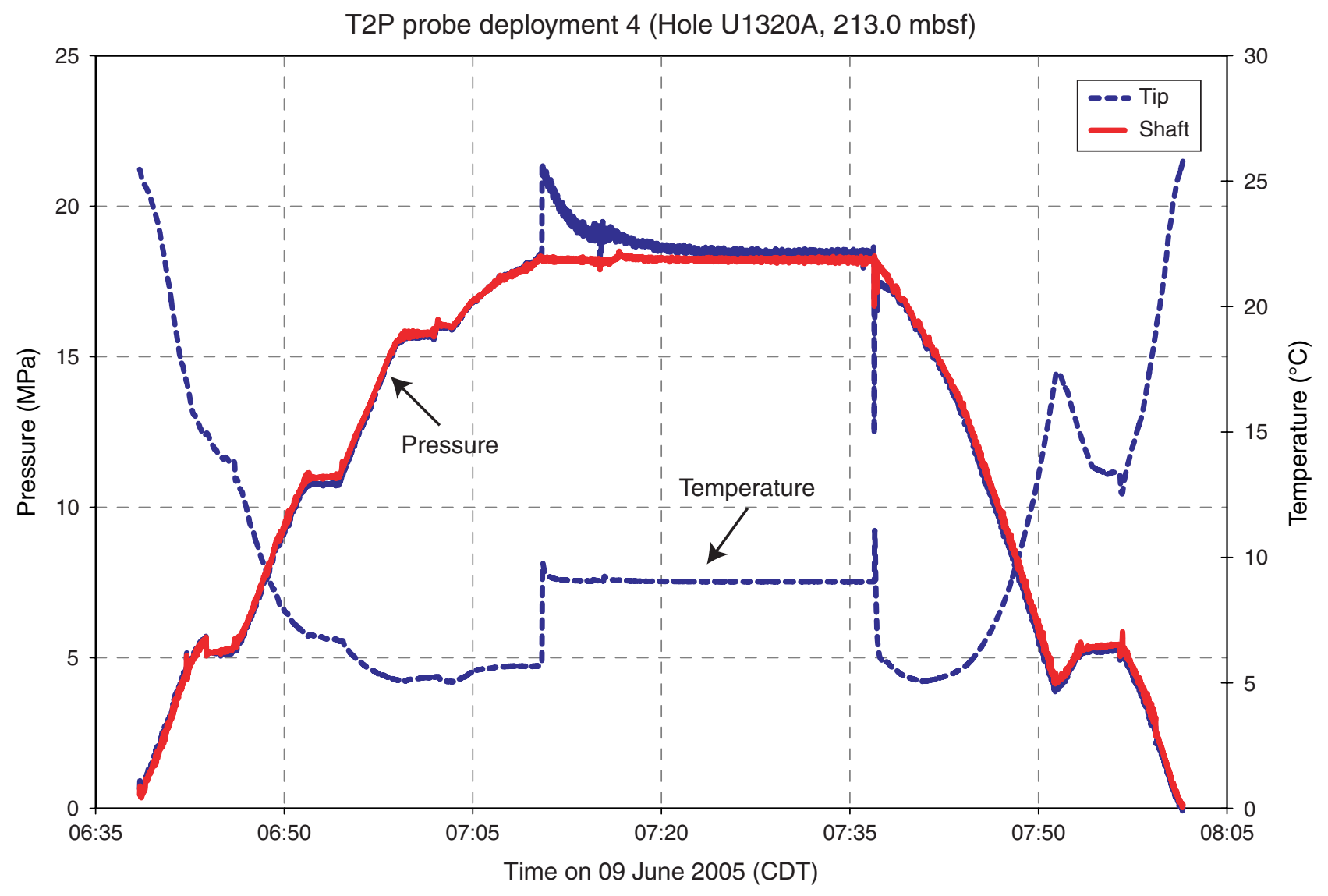


Figure F48. Fluid pressure and temperature measured by Davis-Villinger Temperature-Pressure Probe (DVTPP) Deployment 1. GMT = Greenwich mean time. See "Downhole" in "Supplementary material" for raw data.

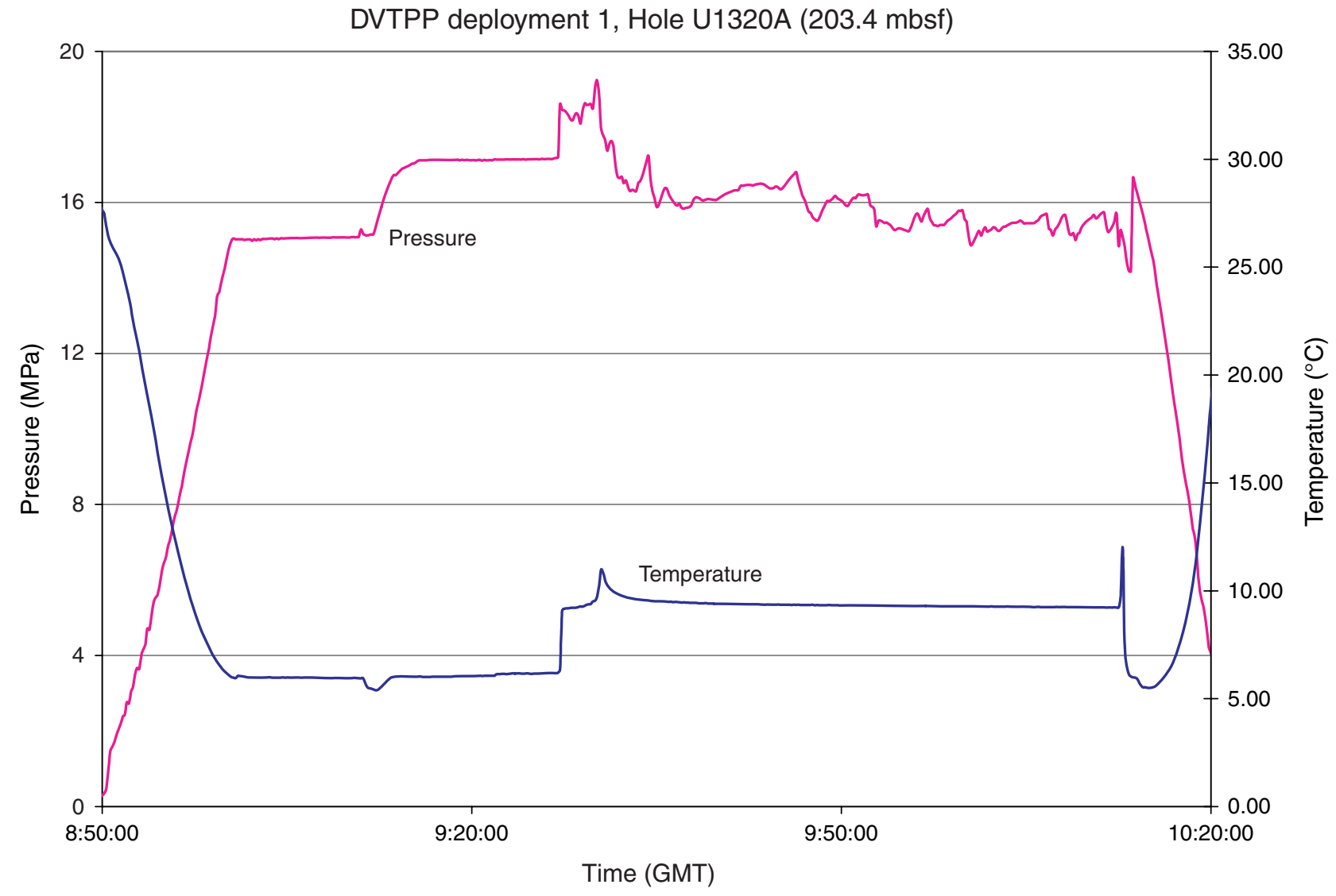


Figure F49. Fluid pressure and temperature measured by Davis-Villinger Temperature-Pressure Probe (DVTPP) Deployment 2. GMT = Greenwich mean time. See "Downhole" in "Supplementary material" for raw data.

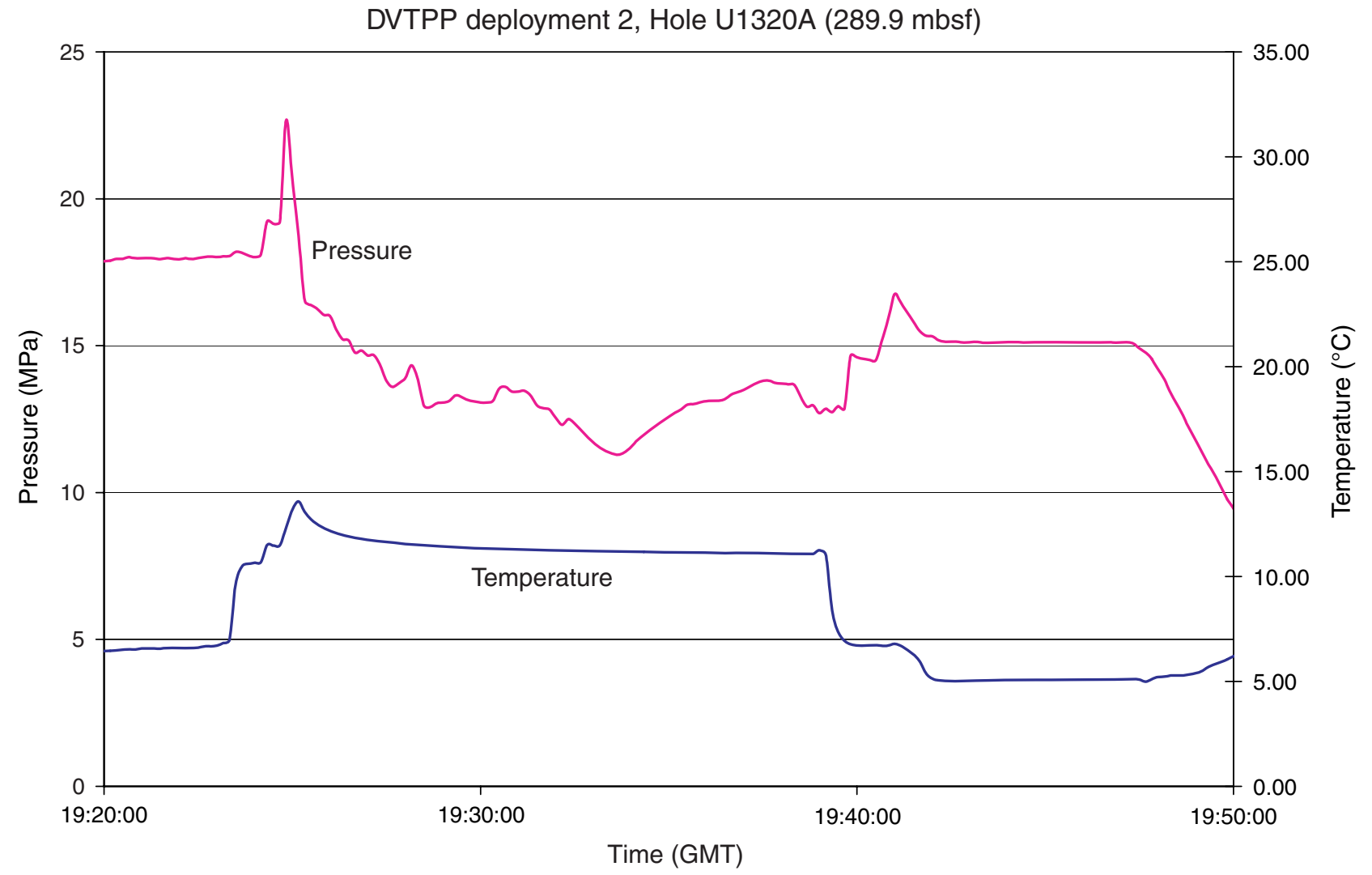


Table T1. Coring summary, Hole U1320A.

\begin{tabular}{|c|c|c|c|c|c|c|c|}
\hline \multirow{2}{*}{\multicolumn{8}{|c|}{ Hole U1320A }} \\
\hline & & & & \multicolumn{4}{|c|}{ Latitude: $27^{\circ} 18.0809^{\prime} \mathrm{N}$} \\
\hline \multicolumn{8}{|c|}{ Longitude: $94^{\circ} 23.2537^{\prime} \mathrm{W}$} \\
\hline \multicolumn{8}{|c|}{$\begin{array}{l}\text { Longitude: } 94^{\circ} 23.2537^{\prime} \mathrm{W} \\
\text { Time on site (h): } 70.08\end{array}$} \\
\hline \multicolumn{8}{|c|}{ Seafloor (drill pipe measurement from rig floor, mbrf): 1480.4} \\
\hline \multicolumn{8}{|c|}{$\begin{array}{l}\text { Distance between rig floor and sea level }(\mathrm{m}): 10.4\end{array}$} \\
\hline \multicolumn{8}{|c|}{ Water depth (drill pipe measurement from sea level, m): 1470} \\
\hline \multicolumn{8}{|c|}{ Total depth (drill pipe measurement from rig floor, mbrf): 1780} \\
\hline \multicolumn{8}{|c|}{ Total penetration (meters below seafloor, mbsf): 299.6} \\
\hline \multicolumn{8}{|c|}{ Total length of cored section $(\mathrm{m}): 299.6$} \\
\hline \multicolumn{8}{|c|}{ Total core recovered $(\mathrm{m}): 250.89$} \\
\hline \multirow{2}{*}{\multicolumn{8}{|c|}{$\begin{array}{l}\text { Core recovery (\%): } 84 \\
\text { Total number of cores: } 33\end{array}$}} \\
\hline \multicolumn{2}{|c|}{ Total number of cores: 33} & & & & & & \\
\hline \multirow[b]{2}{*}{ Core } & \multirow{2}{*}{$\begin{array}{c}\text { Date } \\
\text { (Jun 2005) }\end{array}$} & \multirow{2}{*}{$\begin{array}{l}\text { Local time } \\
\text { (h) }\end{array}$} & \multicolumn{2}{|c|}{ Depth (mbsf) } & \multicolumn{2}{|c|}{ Length $(\mathrm{m})$} & \multirow{2}{*}{$\begin{array}{l}\text { Recovery } \\
\text { (\%) }\end{array}$} \\
\hline & & & Top & Bottom & Cored & Recovered & \\
\hline \multicolumn{8}{|c|}{ 308-U1320A- } \\
\hline $1 \mathrm{H}$ & 8 & 0435 & 0.0 & 4.5 & 4.5 & 4.59 & 102.0 \\
\hline $2 \mathrm{H}$ & 8 & 0625 & 4.5 & 14.0 & 9.5 & 9.59 & 100.9 \\
\hline $3 \mathrm{H}$ & 8 & 0655 & 14.0 & 23.5 & 9.5 & 9.83 & 103.5 \\
\hline $4 \mathrm{H}$ & 8 & 0740 & 23.5 & 33.0 & 9.5 & 9.64 & 101.5 \\
\hline $5 \mathrm{H}$ & 8 & 0850 & 33.0 & 42.5 & 9.5 & 9.86 & 103.8 \\
\hline $6 \mathrm{H}$ & 8 & 0940 & 42.5 & 52.0 & 9.5 & 9.65 & 101.6 \\
\hline $7 \mathrm{H}$ & 8 & 1040 & 52.0 & 60.6 & 8.6 & 8.64 & 100.5 \\
\hline $8 \mathrm{H}$ & 8 & 1140 & 60.6 & 67.3 & 6.7 & 6.73 & 100.4 \\
\hline $9 \mathrm{H}$ & 8 & 1230 & 67.3 & 69.4 & 2.1 & 2.17 & 103.3 \\
\hline $10 x$ & 8 & 1400 & 69.4 & 78.3 & 8.9 & 0.00 & 0.0 \\
\hline $11 \mathrm{X}$ & 8 & 1445 & 78.3 & 87.9 & 9.6 & 2.01 & 20.9 \\
\hline $12 x$ & 8 & 1530 & 87.9 & 97.5 & 9.6 & 5.82 & 60.6 \\
\hline $13 x$ & 8 & 1615 & 97.5 & 107.1 & 9.6 & 0.05 & 0.5 \\
\hline $14 X$ & 8 & 1710 & 107.1 & 116.7 & 9.6 & 5.28 & 55.0 \\
\hline $15 X$ & 8 & 1800 & 116.7 & 126.3 & 9.6 & 9.79 & 102.0 \\
\hline $16 \mathrm{X}$ & 8 & 2135 & 126.3 & 135.9 & 9.6 & 9.85 & 102.6 \\
\hline $17 x$ & 8 & 2250 & 135.9 & 145.6 & 9.7 & 9.75 & 100.5 \\
\hline $18 \mathrm{X}$ & 8 & 2355 & 145.6 & 155.2 & 9.6 & 9.18 & 95.6 \\
\hline $19 x$ & 9 & 0050 & 155.2 & 164.8 & 9.6 & 9.81 & 102.2 \\
\hline $20 x$ & 9 & 0125 & 164.8 & 174.4 & 9.6 & 4.75 & 49.5 \\
\hline $21 x$ & 9 & 0210 & 174.4 & 184.1 & 9.7 & 1.69 & 17.4 \\
\hline $22 X$ & 9 & 0250 & 184.1 & 193.8 & 9.7 & 9.52 & 98.1 \\
\hline $23 x$ & 9 & 0330 & 193.8 & 203.4 & 9.6 & 9.44 & 98.3 \\
\hline $24 X$ & 9 & 0610 & 203.4 & 213.0 & 9.6 & 9.51 & 99.1 \\
\hline $25 X$ & 9 & 0845 & 213.0 & 222.6 & 9.6 & 8.87 & 92.4 \\
\hline $26 X$ & 9 & 0925 & 222.6 & 232.2 & 9.6 & 9.87 & 102.8 \\
\hline $27 X$ & 9 & 1000 & 232.2 & 241.9 & 9.7 & 9.63 & 99.3 \\
\hline $28 \mathrm{X}$ & 9 & 1045 & 241.9 & 251.5 & 9.6 & 9.34 & 97.3 \\
\hline $29 x$ & 9 & 1125 & 251.5 & 261.1 & 9.6 & 9.09 & 94.7 \\
\hline $30 x$ & 9 & 1210 & 261.1 & 270.7 & 9.6 & 9.52 & 99.2 \\
\hline $31 x$ & 9 & 1300 & 270.7 & 280.3 & 9.6 & 9.70 & 101.0 \\
\hline $32 X$ & 9 & 1350 & 280.3 & 289.9 & 9.6 & 8.01 & 83.4 \\
\hline $33 x$ & 9 & 1615 & 289.9 & 299.6 & 9.7 & 9.71 & 100.1 \\
\hline & & & & ed totals: & 299.6 & 250.89 & 83.7 \\
\hline
\end{tabular}


Table T2. Coring summary, Hole U1320B.

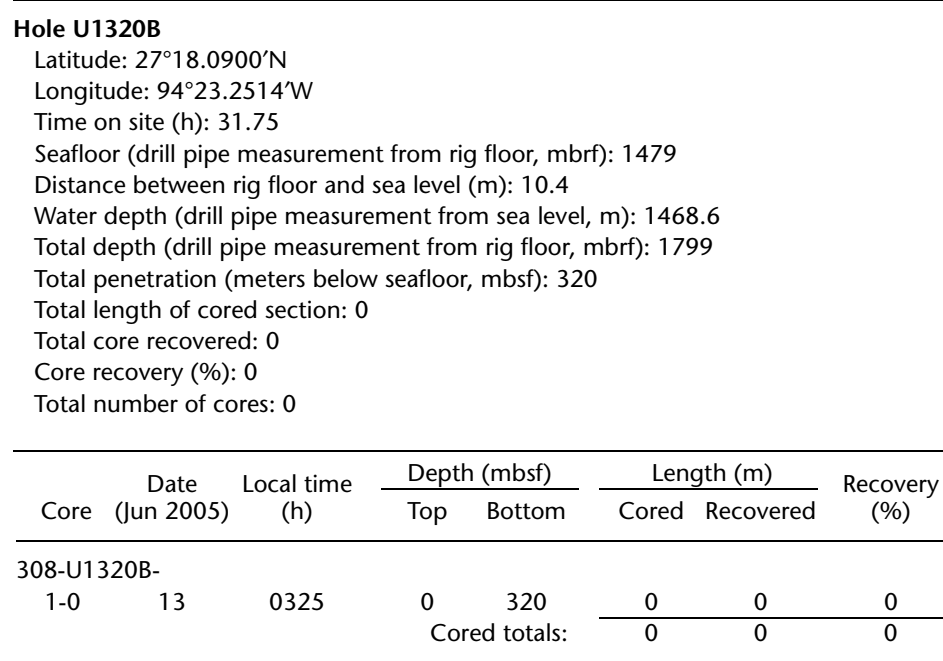

Table T3. Lithostratigraphic units, Hole U1320A.

\begin{tabular}{|c|c|c|c|c|c|c|c|}
\hline \multirow[b]{2}{*}{ Unit } & \multicolumn{2}{|l|}{ Top } & \multicolumn{2}{|c|}{ Bottom } & \multirow[b]{2}{*}{$\begin{array}{l}\text { Thickness } \\
(\mathrm{m})\end{array}$} & \multirow[b]{2}{*}{$\begin{array}{l}\text { Sand } \\
(\%)\end{array}$} & \multirow[b]{2}{*}{ Lithology/Remarks } \\
\hline & $\begin{array}{l}\text { Core, section, } \\
\text { interval }(\mathrm{cm})\end{array}$ & $\begin{array}{l}\text { Depth } \\
\text { (mbsf) }\end{array}$ & $\begin{array}{l}\text { Core, section, } \\
\text { interval (cm) }\end{array}$ & $\begin{array}{l}\text { Depth } \\
\text { (mbsf) }\end{array}$ & & & \\
\hline I & $\begin{array}{l}\text { 308-U1320A- } \\
1 \mathrm{H}-1,0\end{array}$ & 0 & $\begin{array}{c}\text { 308-U1320A- } \\
1 \mathrm{H}-2,115\end{array}$ & 2.65 & 2.65 & 0 & Clay, foraminifer bearing \\
\hline II & $1 \mathrm{H}-2,115$ & 2.65 & $17 X-2,91$ & 137.5 & 134.85 & 49 & Sand and mud, three main packages \\
\hline IIA & $1 \mathrm{H}-2,115$ & 2.65 & $4 \mathrm{H}-3,110$ & 27.6 & 24.95 & 70 & Sand and mud, three main packages \\
\hline IIB & $4 \mathrm{H}-3,110$ & 27.6 & $5 \mathrm{H}-4,26$ & 37.76 & 10.16 & 0 & Clay, bioturbated, organic-rich silt laminae \\
\hline IIC & $5 \mathrm{H}-4,26$ & 37.76 & 11X-log, log & 82 & 44.24 & 77 & Sand and mud interbedded, four main packages \\
\hline IID & 11X-log, log & 82 & $15 X-6,40$ & 124.6 & 42.6 & 32 & Sand and mud interbedded, two main packages \\
\hline IIE & $15 X-6,40$ & 124.6 & $17 X-2,91$ & 137.5 & 12.9 & 10 & Clay, mass transport deposit \\
\hline III & $17 X-2,91$ & 137.5 & 17X-CC, 20 & 145.3 & 7.8 & 0 & Clay, foraminifer bearing (contains ash Layer Y8) \\
\hline IV & 17X-CC, 20 & 145.3 & $21 X-1,0$ & 174.4 & 29.1 & 23 & Clay, with thin sand and silt beds, thick sand bed at base \\
\hline $\mathrm{V}$ & $21 X-1,0$ & 174.4 & 33X-CC, 39 & 299.61 & 125.21 & 0 & Clay, bioturbated (probable foraminifer-bearing clay at top) \\
\hline
\end{tabular}




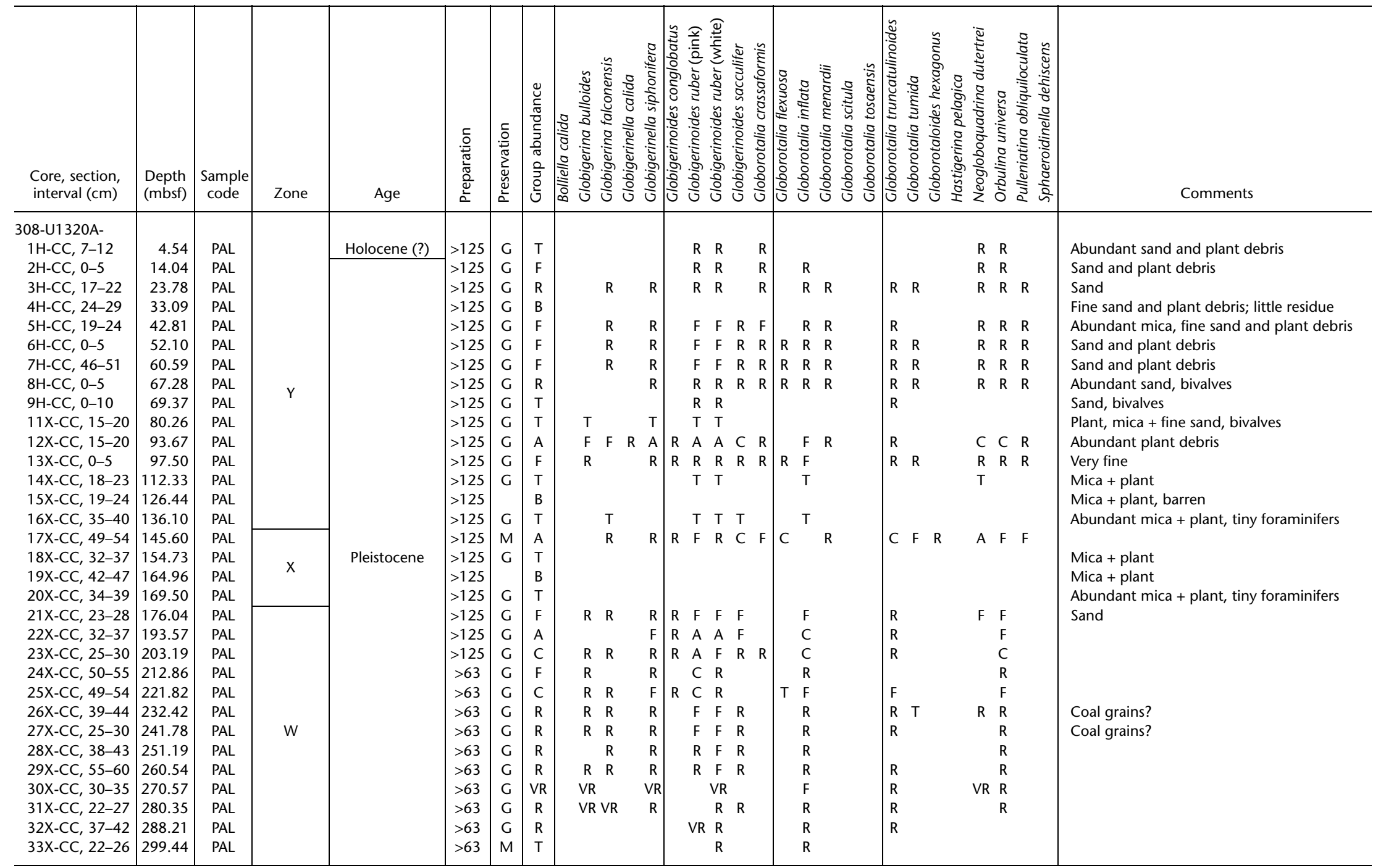

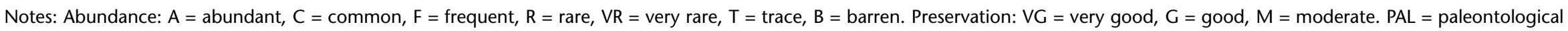
sample. 


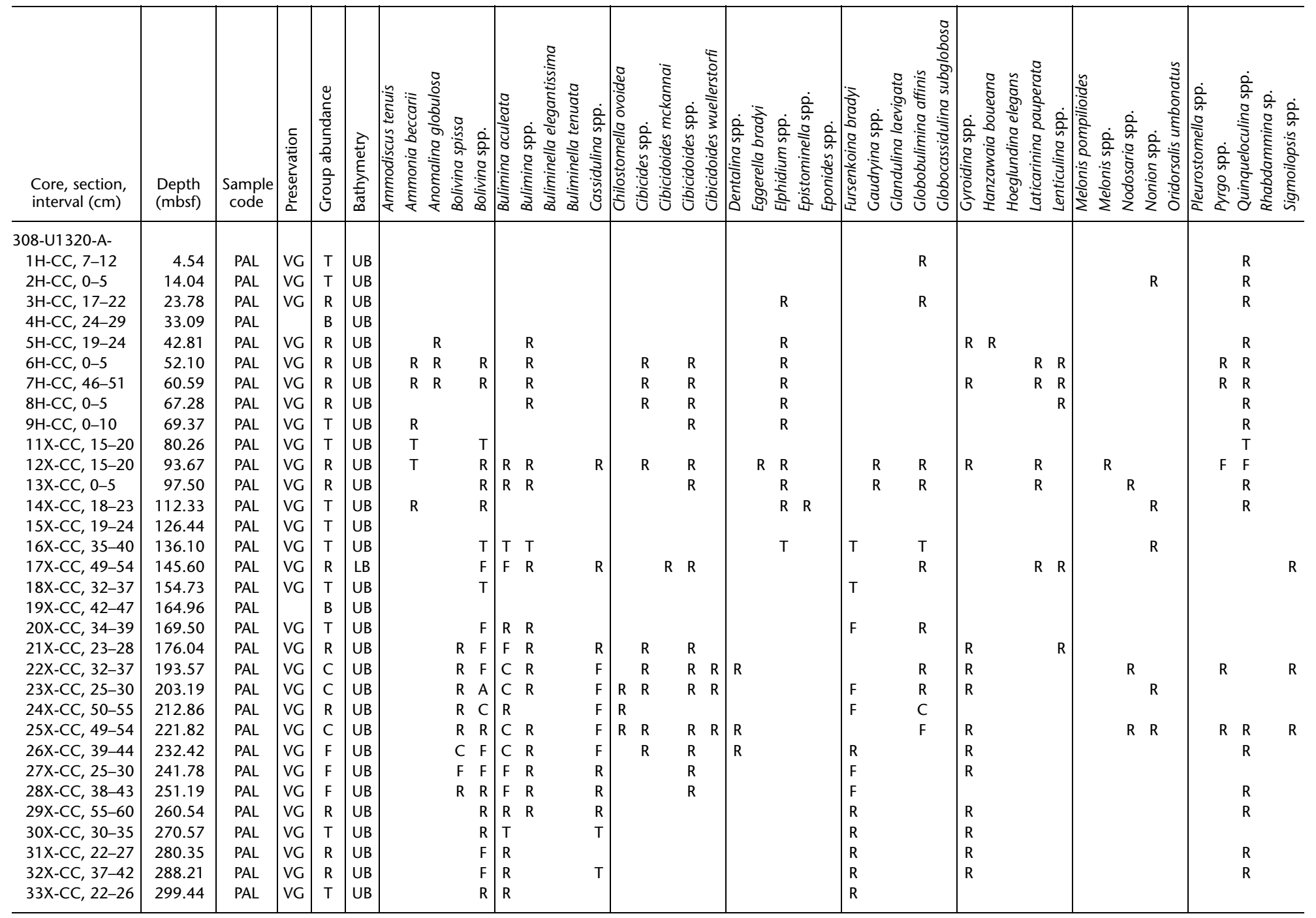

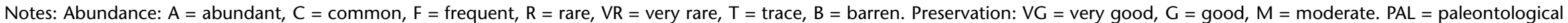
sample. UB = upper bathyal. 


\begin{tabular}{|c|c|c|c|c|c|c|c|c|}
\hline $\begin{array}{l}\text { Core, section, } \\
\text { interval }(\mathrm{cm})\end{array}$ & $\begin{array}{l}\text { Depth } \\
\text { (mbsf) }\end{array}$ & $\begin{array}{c}\text { Sample } \\
\text { code }\end{array}$ & 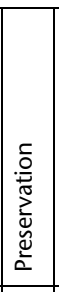 & 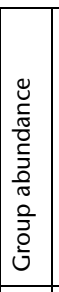 & 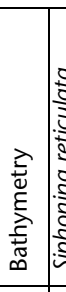 & 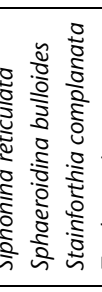 & 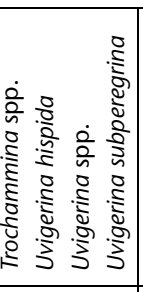 & Comments \\
\hline $\begin{array}{l}\text { 308-U1320-A- } \\
1 \mathrm{H}-\mathrm{CC} .7-12\end{array}$ & 4.54 & PAL & & $T$ & $M B$ & & & Abundant sand and plant debris \\
\hline $2 \mathrm{H}-\mathrm{CC}, 0-5$ & 14.04 & PAL & VG & $\mathrm{T}$ & UB & & $\mathrm{R}$ & Sand and plant debris \\
\hline $3 \mathrm{H}-\mathrm{CC}, 17-22$ & 23.78 & PAL & va & $\mathrm{R}$ & $\mathrm{UB}$ & & $\mathrm{R}$ & Sand \\
\hline $4 \mathrm{H}-\mathrm{CC}, 24-29$ & 33.09 & PAL & & B & UB & & & Fine sand and plant debris; little residue \\
\hline $5 \mathrm{H}-\mathrm{CC}, 19-24$ & 42.81 & PAL & va & $\mathrm{R}$ & UB & $\mathrm{R}$ & $\mathrm{R}$ & Abundant mica, fine sand and plant debris \\
\hline $6 \mathrm{H}-\mathrm{CC}, 0-5$ & 52.10 & PAL & $\mathrm{vG}$ & $\mathrm{R}$ & UB & $\mathrm{R}$ & $\mathrm{R}$ & Sand and plant debris \\
\hline $7 \mathrm{H}-\mathrm{CC}, 46-51$ & 60.59 & PAL & vG & $\mathrm{R}$ & UB & $\mathrm{R}$ & $\mathrm{R}$ & Sand and plant debris \\
\hline $8 \mathrm{H}-\mathrm{CC}, 0-5$ & 67.28 & PAL & vG & $\mathrm{R}$ & UB & & & Abundant sand, bivalves \\
\hline $9 \mathrm{H}-\mathrm{CC}, 0-10$ & 69.37 & PAL & va & $\mathrm{T}$ & UB & & & Sand, bivalves \\
\hline $11 \mathrm{X}-\mathrm{CC}, 15-20$ & 80.26 & PAL & vG & $\mathrm{T}$ & UB & & & Plant, mica + fine sand, bivalves \\
\hline $12 \mathrm{X}-\mathrm{CC}, 15-20$ & 93.67 & PAL & vg & $\mathrm{R}$ & UB & $\mathrm{F}$ & & Abundant plant debris, abundant planktonic foraminifers \\
\hline $13 \mathrm{X}-\mathrm{CC}, 0-5$ & 97.50 & PAL & VG & $\mathrm{R}$ & UB & & $\mathrm{R}$ & Very fine \\
\hline $14 \mathrm{X}-\mathrm{CC}, 18-23$ & 112.33 & PAL & vo & $\mathrm{T}$ & UB & & & Mica + plant \\
\hline $15 X-C C, 19-24$ & 126.44 & PAL & VG & $T$ & UB & & & Mica + plant, barren \\
\hline $16 \mathrm{X}-\mathrm{CC}, 35-40$ & 136.10 & PAL & VG & $\mathrm{T}$ & UB & & & Abundant mica + plant, tiny foraminifers \\
\hline $17 \mathrm{X}-\mathrm{CC}, 49-54$ & 145.60 & PAL & $\mathrm{VG}$ & $\mathrm{R}$ & LB & $\mathrm{R}$ & $R \quad R$ & \\
\hline $18 \mathrm{X}-\mathrm{CC}, 32-37$ & 154.73 & PAL & VG & $\mathrm{T}$ & UB & & & Very rare \\
\hline $19 X-C C, 42-47$ & 164.96 & PAL & & B & UB & & & \\
\hline $20 \mathrm{X}-\mathrm{CC}, 34-39$ & 169.50 & PAL & vg & $\mathrm{T}$ & UB & & & Very rare \\
\hline $21 \mathrm{X}-\mathrm{CC}, 23-28$ & 176.04 & PAL & VG & $\mathrm{R}$ & UB & & $\mathrm{R} R$ & \\
\hline $22 \mathrm{X}-\mathrm{CC}, 32-37$ & 193.57 & PAL & va & c & UB & $\mathrm{R}$ & $C R$ & \\
\hline $23 \mathrm{X}-\mathrm{CC}, 25-30$ & 203.19 & PAL & vG & c & UB & $\mathrm{F}$ & $\mathrm{F} R$ & \\
\hline $24 \mathrm{X}-\mathrm{CC}, 50-55$ & 212.86 & PAL & VG & $\mathrm{R}$ & $\mathrm{UB}$ & $\mathrm{F}$ & & \\
\hline $25 \mathrm{X}-\mathrm{CC}, 49-54$ & 221.82 & PAL & vG & C & UB & $\mathrm{F}$ & $\mathrm{R}$ & \\
\hline $26 \mathrm{X}-\mathrm{CC}, 39-44$ & 232.42 & PAL & vG & $\mathrm{F}$ & UB & & $\begin{array}{lll}F & R & R\end{array}$ & Coal grains? \\
\hline $27 \mathrm{X}-\mathrm{CC}, 25-30$ & 241.78 & PAL & VG & $\mathrm{F}$ & $\mathrm{UB}$ & & $\begin{array}{lll}F & R & R\end{array}$ & Coal grains? \\
\hline $28 \mathrm{X}-\mathrm{CC}, 38-43$ & 251.19 & PAL & vG & $\mathrm{F}$ & UB & & & Rare \\
\hline $29 \mathrm{X}-\mathrm{CC}, 55-60$ & 260.54 & PAL & vo & $\mathrm{R}$ & UB & & $\mathrm{R}$ & \\
\hline $30 \mathrm{X}-\mathrm{CC}, 30-35$ & 270.57 & PAL & vo & $\mathrm{T}$ & $\mathrm{UB}$ & & & Very rare \\
\hline $31 \mathrm{X}-\mathrm{CC}, 22-27$ & 280.35 & PAL & vo & $\mathrm{R}$ & UB & & & Very rare \\
\hline $32 \mathrm{X}-\mathrm{CC}, 37-42$ & 288.21 & PAL & VG & $\mathrm{R}$ & UB & & & Very rare \\
\hline $33 \mathrm{X}-\mathrm{CC}, 22-26$ & 299.44 & PAL & vG & $\mathrm{T}$ & UB & & & Very rare \\
\hline
\end{tabular}


Table T6. Datums used to plot Figure F15, Hole U1320A.

\begin{tabular}{|c|c|c|c|c|c|c|c|c|}
\hline \multirow[b]{2}{*}{ Code } & \multirow[b]{2}{*}{ Event } & \multicolumn{2}{|l|}{ Top } & \multicolumn{2}{|l|}{ Bottom } & \multirow[b]{2}{*}{$\begin{array}{l}\text { Age } \\
(\mathrm{ka})\end{array}$} & \multirow{2}{*}{$\begin{array}{l}\text { Average } \\
\text { depth } \\
\text { (mbsf) }\end{array}$} & \multirow{2}{*}{$\begin{array}{c}\text { Average } \\
\text { sedimentation } \\
\text { rate ( } \mathrm{m} / \mathrm{k} . \mathrm{y} .)\end{array}$} \\
\hline & & $\begin{array}{l}\text { Core, section, } \\
\text { interval }(\mathrm{cm})\end{array}$ & $\begin{array}{l}\text { Depth } \\
\text { (mbsf) }\end{array}$ & $\begin{array}{l}\text { Core, section, } \\
\text { interval }(\mathrm{cm})\end{array}$ & $\begin{array}{l}\text { Depth } \\
\text { (mbsf) }\end{array}$ & & & \\
\hline & & 308-1320A- & & 308-1320A- & & & & \\
\hline PF & LO G. inflata & $1 \mathrm{H}-\mathrm{CC}, 7-12$ & 4.54 & $2 \mathrm{H}-\mathrm{CC}, 0-5$ & 14.04 & 10 & 9.29 & 0.93 \\
\hline PF & LO G. flexuosa? & $12 \mathrm{X}-\mathrm{CC}, 15-20$ & 93.67 & $13 \mathrm{X}-\mathrm{CC}, 0-5$ & 97.50 & 68 & 95.59 & \\
\hline \multirow[t]{2}{*}{$\mathrm{CN}$} & FO E. huxleyi acme & $17 C X-5,5$ & 141.25 & $17 X-5,145$ & 142.60 & 90 & 141.92 & \\
\hline & Ash Layer Y8 & & & & 143.42 & 84 & & 1.8 \\
\hline MS & Tie point 5 (= MIS $5 b)$ & & & & 132.00 & 86 & 132.00 & 0.20 \\
\hline MS & Tie point 6 (= MIS 5c) & & & & 138.00 & 97 & 138.00 & \\
\hline MS & Tie point 7 (= MIS $5 d)$ & & & & 148.00 & 106 & 148.00 & \\
\hline $\mathrm{CN}$ & No occurrence of $H$. inversa & & & $33 X-C C, 22-26$ & 299.44 & $<150$ & 299.44 & $>2.60 ?$ \\
\hline
\end{tabular}

Notes: $\mathrm{PF}=$ planktonic foraminifer, $\mathrm{MS}=$ magnetostratigraphy, $\mathrm{CN}=$ calcareous nannofossil. $\mathrm{FO}=$ first occurrence; $\mathrm{LO}=$ last occurrence. The datum level for $G$. flexuosa is considered unreliable and should be discarded when calculating sedimentation rates. High sedimentation rates from the lower part of the hole need confirmation by postcruise studies.

Table T7. Summary of pass-through cryogenic magnetometer measurements, Site U1320.

\begin{tabular}{ll}
\hline \multicolumn{1}{c}{ Measurement } & \multicolumn{1}{c}{ Core, section } \\
\hline & $308-\mathrm{U} 1320 \mathrm{~A}-$ \\
Natural remanent magnetization $(0,15,20 \mathrm{mT})$ & $1 \mathrm{H}-1$ through 33X-CC \\
Skipped sections & $2 \mathrm{H}-2$ through $2 \mathrm{H}-6,3 \mathrm{H}-1,4 \mathrm{H}-1,6 \mathrm{H}-4,8 \mathrm{H}-5,8 \mathrm{H}-6,9 \mathrm{H}-1$, and 9H-2 \\
Tensor tool & $4 \mathrm{H}$ through $9 \mathrm{H}$ \\
\hline
\end{tabular}

Table T8. Magnetostratigraphic tie points, Site U1320.

\begin{tabular}{lrr}
\hline $\begin{array}{c}\text { Magnetostratigraphic } \\
\text { tie point }\end{array}$ & MIS & $\begin{array}{r}\text { Age } \\
\text { (ka) }\end{array}$ \\
\hline MTP1 & & \\
MTP2 & 3.3 & 52 \\
MTP3 & 4.2 & 65 \\
MTP4 & & \\
MTP5 & 5.2 & 86 \\
MTP6 & 5.3 & 97 \\
MTP7 & 5.4 & 106 \\
MTP8 & & \\
MTP9 & & \\
MTP10 & & \\
MTP11 & & \\
MTP12 & & \\
Lake Mungo Excursion & & 35 \\
\hline
\end{tabular}

Note: MIS = marine isotope stage. Corresponding MIS and ages assigned according to Bassinot et al. (1994). 
Table T9. Pore water chemistry, Hole U1320A.

\begin{tabular}{|c|c|c|c|c|c|c|c|c|c|c|c|c|c|c|c|c|c|c|c|}
\hline $\begin{array}{l}\text { Core, section, } \\
\text { interval }(\mathrm{cm})\end{array}$ & $\begin{array}{l}\text { Depth } \\
\text { (mbsf) }\end{array}$ & $\begin{array}{l}\text { Alkalinity } \\
(\mathrm{mM})\end{array}$ & $\mathrm{pH}$ & $\begin{array}{c}\text { Salinity } \\
\text { (pph) }\end{array}$ & $\begin{array}{c}\text { Chlorinity } \\
(\mathrm{mM})\end{array}$ & $\begin{array}{l}\mathrm{SO}_{4}{ }^{2-} \\
(\mathrm{mM})\end{array}$ & $\begin{array}{l}\mathrm{NH}_{4}^{+} \\
(\mathrm{mM})\end{array}$ & $\begin{array}{l}\mathrm{PO}_{4}^{3-} \\
(\mathrm{mM})\end{array}$ & $\begin{array}{c}\mathrm{H}_{4} \mathrm{SiO}_{4} \\
(\mathrm{nM})\end{array}$ & $\begin{array}{l}\mathrm{Na}^{+} \\
(\mathrm{mM})\end{array}$ & $\begin{array}{c}\mathrm{K}^{+} \\
(\mathrm{mM})\end{array}$ & $\begin{array}{l}\mathrm{Mg}^{2+} \\
(\mathrm{mM})\end{array}$ & $\begin{array}{l}\mathrm{Ca}^{2+} \\
(\mathrm{mM})\end{array}$ & $\begin{array}{c}\mathrm{B}^{3+} \\
(\mathrm{nM})\end{array}$ & $\begin{array}{c}\mathrm{Li}^{+} \\
(\mu \mathrm{M})\end{array}$ & $\begin{array}{l}\mathrm{Sr}^{2+} \\
(\mu \mathrm{M})\end{array}$ & $\begin{array}{l}\mathrm{Ba}^{2+} \\
(\mu \mathrm{M})\end{array}$ & $\begin{array}{l}\mathrm{Fe}^{2+} \\
(\mu \mathrm{M})\end{array}$ & $\begin{array}{l}\mathrm{Mn}^{2+} \\
(\mu \mathrm{M})\end{array}$ \\
\hline \multicolumn{20}{|l|}{ 308-U1320A- } \\
\hline $1 \mathrm{H}-1,145-150$ & 1.45 & 4.77 & 7.72 & 3.6 & 551 & 24.4 & 132 & 10.8 & 271 & 457 & 12.6 & 49.8 & 10.1 & 436 & 24.5 & 91.9 & 0.7 & 1.1 & 145.4 \\
\hline $1 \mathrm{H}-2,137-142$ & 2.87 & 5.81 & 7.66 & 3.6 & 558 & 23.6 & 275 & 25.2 & 352 & 467 & 12.8 & 50.1 & 9.7 & 441 & 23.3 & 90.8 & 0.7 & 1.5 & 108.3 \\
\hline $1 \mathrm{H}-3,132-137$ & 4.32 & & & & 558 & 19.6 & 603 & 31.3 & 388 & 433 & 11.1 & 45.8 & 8.9 & 558 & 21.9 & 87.4 & 1.0 & 5.6 & 78.5 \\
\hline $2 \mathrm{H}-2,137-142$ & 5.82 & & & & 560 & 16.0 & 998 & 13.2 & 261 & 464 & 11.7 & 48.0 & 9.0 & 553 & 18.7 & 82.6 & 0.8 & 0.3 & 16.6 \\
\hline $2 \mathrm{H}-6,145-150$ & 13.50 & & & & 571 & 14.0 & 650 & 12.3 & & 455 & 11.5 & 47.0 & 8.3 & & & & & & \\
\hline $2 \mathrm{H}-7,49-54$ & 13.99 & 12.84 & 7.58 & 3.5 & 557 & 11.8 & 1123 & 41.4 & 449 & 444 & 10.7 & 43.7 & 7.9 & 779 & 16.7 & 80.8 & 1.1 & 9.7 & 12.1 \\
\hline $3 \mathrm{H}-1,145-150$ & 15.45 & 15.99 & 7.84 & 3.5 & 559 & 6.1 & 1231 & 68.1 & 406 & 447 & 10.3 & 42.3 & 6.7 & 623 & 14.0 & 75.0 & 2.5 & 1.9 & 2.9 \\
\hline $3 \mathrm{H}-5,127-132$ & 21.27 & & & & 562 & 0.6 & 1433 & 45.2 & 609 & 452 & 7.6 & 43.6 & 5.7 & 670 & 11.5 & 76.4 & 8.2 & 10.0 & 2.4 \\
\hline $4 \mathrm{H}-3,137-142$ & 27.87 & 9.26 & 7.51 & 3.3 & 569 & 0.7 & 1740 & 4.3 & 453 & 437 & 7.5 & 41.6 & 5.3 & 647 & 14.0 & 73.3 & 9.4 & 14.3 & 2.9 \\
\hline $4 \mathrm{H}-4,145-150$ & 29.45 & & & & 574 & 0.6 & 1550 & 9.0 & 274 & 456 & 8.2 & 42.9 & 5.4 & 531 & 12.9 & 71.4 & 9.5 & 6.2 & 1.9 \\
\hline $4 \mathrm{H}-5,145-150$ & 30.95 & 8.79 & 7.53 & 3.3 & 571 & & 2715 & 5.5 & 442 & 435 & 7.7 & 41.9 & 5.4 & 703 & 13.0 & 75.0 & 8.7 & 27.5 & 2.6 \\
\hline $4 \mathrm{H}-7,45-50$ & 32.80 & & & & 571 & 0.8 & 777 & 4.8 & 475 & 426 & 7.4 & 41.6 & 5.4 & 714 & 12.5 & 73.8 & 9.1 & 17.9 & 2.7 \\
\hline $5 \mathrm{H}-1,145-150$ & 34.45 & & & & 572 & 1.3 & 2828 & 6.0 & 282 & 433 & 8.2 & 41.2 & 5.3 & 515 & 13.9 & 71.5 & 8.6 & 2.5 & 1.4 \\
\hline $5 \mathrm{H}-3,137-142$ & 37.37 & 8.92 & 7.60 & 3.4 & 569 & 1.1 & 2258 & 8.1 & 251 & 443 & 8.7 & 42.0 & 5.3 & 536 & 14.2 & 72.1 & 9.6 & 0.7 & 1.4 \\
\hline $5 \mathrm{H}-5,145-150$ & 40.45 & & & & 569 & 0.8 & 2299 & 15.3 & 428 & 458 & 9.0 & 44.2 & 5.7 & 574 & 13.0 & 74.8 & 10.4 & 52.3 & 3.6 \\
\hline $6 \mathrm{H}-3,145-150$ & 47.00 & & & & 559 & 2.7 & 2269 & 13.6 & & 461 & 8.8 & 46.5 & 6.2 & & & & & & \\
\hline 7H-5, 137-142 & 59.50 & & & & 571 & 0.7 & 2663 & 13.6 & 332 & 349 & 6.2 & 32.7 & 4.2 & 507 & 11.8 & 70.6 & 7.7 & 1.2 & 2.0 \\
\hline $8 \mathrm{H}-2,145-150$ & 63.30 & & & & 593 & 1.7 & 2385 & 9.0 & 95 & 482 & 10.2 & 43.3 & 5.5 & 336 & 12.0 & 68.8 & 8.6 & 0.3 & 0.0 \\
\hline $9 \mathrm{H}-1,132-137$ & 68.80 & & & 3.5 & & & & & & & & & & & & & & & \\
\hline $12 X-3,137-142$ & 92.27 & 11.16 & 7.55 & 3.4 & 565 & 2.3 & 3816 & 9.2 & 563 & 455 & 8.8 & 44.1 & 6.5 & 673 & 18.1 & 81.9 & 13.6 & 27.3 & 4.1 \\
\hline $14 X-4,145-150$ & 111.60 & & & & & & & & & & & & & & & & & & \\
\hline $15 X-3,136-141$ & 121.06 & 5.28 & 7.78 & 3.4 & 564 & 3.5 & 2082 & 3.0 & 193 & 439 & 7.3 & 43.5 & 6.4 & 537 & 23.4 & 81.6 & 23.9 & 1.2 & 2.4 \\
\hline $16 X-3,145-150$ & 130.75 & 7.76 & 7.58 & 3.4 & 564 & 3.2 & 2041 & 2.0 & 251 & 446 & 8.5 & 42.8 & 5.9 & 576 & 28.0 & 78.1 & 31.3 & 0.0 & 18.0 \\
\hline $17 X-5,137-142$ & 141.20 & & & & & & & & & & & & & & & & & & \\
\hline $18 X-3,145-150$ & 150.05 & 10.27 & 7.80 & & 561 & 5.9 & 2864 & 32.4 & 225 & 450 & 8.0 & 46.3 & 7.3 & 372 & 16.2 & 90.1 & 7.6 & 0.0 & 3.9 \\
\hline $19 X-3,137-142$ & 159.57 & & & & 560 & 4.6 & 2163 & 2.8 & 233 & 420 & 7.1 & 43.1 & 8.2 & 370 & 17.6 & 96.0 & 10.3 & 3.8 & 2.6 \\
\hline $20 \times-2,145-150$ & 167.75 & 6.00 & 7.18 & 3.4 & 561 & 3.6 & 1898 & 1.3 & 467 & 435 & 6.6 & 44.5 & 9.8 & 607 & 16.6 & 102.5 & 29.0 & 64.5 & 9.8 \\
\hline $21 \mathrm{X}-1,136-141$ & 175.84 & 3.54 & 7.22 & 3.4 & 557 & 6.8 & 1937 & 4.1 & 370 & 424 & 6.1 & 45.9 & 11.1 & 522 & 24.0 & 103.5 & 21.0 & 20.7 & 5.8 \\
\hline $22 X-3,145-150$ & 188.55 & 3.05 & 7.46 & 3.5 & 561 & 2.1 & 3316 & 2.7 & 239 & 441 & 7.7 & 41.2 & 10.8 & 388 & 25.3 & 100.4 & 26.7 & 1.4 & 3.2 \\
\hline $23 X-1,132-150$ & 195.12 & 3.59 & 7.09 & 3.4 & 570 & 2.6 & 2593 & 4.4 & 312 & 433 & 5.8 & 43.0 & 11.7 & 472 & 21.5 & 111.4 & 15.6 & 36.0 & 3.5 \\
\hline $23 X-5,137-142$ & 201.17 & 3.07 & 7.37 & 3.5 & 575 & 2.2 & 3809 & 3.0 & 201 & 440 & 6.8 & 41.8 & 11.0 & 320 & 23.8 & 105.6 & 12.8 & 3.8 & 2.5 \\
\hline $24 X-3,145-150$ & 207.85 & & & & 569 & 3.4 & 2914 & 0.7 & 182 & 447 & 6.1 & 43.4 & 11.7 & 367 & 17.5 & 107.8 & 10.5 & 12.0 & 2.3 \\
\hline $25 X-3,140-150$ & 217.40 & 4.02 & 7.16 & 3.4 & 562 & 3.1 & 2348 & 0.9 & 228 & 453 & 4.8 & 45.5 & 12.9 & 460 & 14.8 & 120.8 & 9.9 & 32.0 & 2.9 \\
\hline $26 X-3,137-142$ & 226.78 & 4.27 & 7.19 & 3.4 & 566 & 4.1 & 3742 & 4.3 & 309 & 434 & 4.3 & 43.9 & 12.8 & 420 & 21.5 & 119.7 & 11.0 & 9.2 & 3.3 \\
\hline $27 X-3,140-150$ & 236.60 & 3.55 & 7.11 & 3.4 & 565 & 2.8 & 3493 & 0.9 & 301 & 446 & 4.4 & 42.2 & 13.1 & 382 & 22.1 & 121.1 & 12.9 & 27.2 & 3.9 \\
\hline $28 X-3,140-150$ & 246.30 & 3.70 & 7.21 & 3.4 & 576 & 5.4 & 2943 & 0.7 & 261 & 451 & 4.4 & 43.4 & 13.2 & 391 & 19.5 & 125.5 & 15.6 & 13.1 & 3.4 \\
\hline $29 \times-3,132-142$ & 255.82 & 3.25 & 7.45 & 3.5 & 578 & 3.3 & 2222 & 4.3 & 159 & 441 & 4.3 & 41.2 & 12.3 & 353 & 13.7 & 114.0 & 15.0 & 0.7 & 2.4 \\
\hline $30 X-3,140-150$ & 265.50 & 3.87 & 7.37 & 3.5 & 547 & 2.1 & 3181 & 1.6 & 200 & 445 & 4.0 & 41.4 & 12.8 & 360 & 14.3 & 110.9 & 15.6 & 3.2 & 2.7 \\
\hline $31 X-3,140-150$ & 275.10 & 4.03 & 7.47 & 3.4 & 574 & 1.9 & 3027 & 1.4 & 188 & 436 & 4.1 & 40.8 & 12.6 & 368 & 16.6 & 113.5 & 16.8 & 0.0 & 2.7 \\
\hline $32 X-3,132-142$ & 284.62 & 3.74 & 7.54 & 3.5 & 576 & 2.9 & 2507 & 1.1 & 154 & 453 & 3.8 & 42.6 & 12.5 & 286 & 10.4 & 79.7 & 10.0 & 3.7 & 2.0 \\
\hline $33 X-3,140-150$ & 294.30 & 4.11 & 7.43 & 3.5 & 580 & 1.8 & 3059 & 1.4 & 191 & 436 & 4.2 & 39.3 & 10.8 & 399 & 16.1 & 106.0 & 16.0 & 1.4 & 1.9 \\
\hline
\end{tabular}


Table T10. Sediment elemental analysis, Hole U1320A.

\begin{tabular}{|c|c|c|c|c|c|c|c|c|}
\hline \multirow{2}{*}{$\begin{array}{l}\text { Core, section, } \\
\text { interval }(\mathrm{cm})\end{array}$} & \multirow{2}{*}{$\begin{array}{l}\text { Depth } \\
\text { (mbsf) }\end{array}$} & \multicolumn{4}{|c|}{ Carbon (wt\%) } & \multirow{2}{*}{$\begin{array}{c}\text { TN } \\
\text { (wt\%) }\end{array}$} & \multirow{2}{*}{$\begin{array}{c}\mathrm{TH} \\
\text { (wt\%) }\end{array}$} & \multirow{2}{*}{$\begin{array}{c}\mathrm{C} / \mathrm{N} \\
\text { (mol:mol) }\end{array}$} \\
\hline & & Total & Inorganic & $\mathrm{CaCO}_{3}$ & Organic & & & \\
\hline \multicolumn{9}{|l|}{ 308-U1320A- } \\
\hline $1 \mathrm{H}-1,145-150$ & 1.45 & 2.78 & 2.18 & 18.15 & 0.60 & 0.24 & 0.88 & 2.91 \\
\hline $1 \mathrm{H}-2,137-142$ & 2.87 & 2.10 & 1.48 & 12.37 & 0.62 & 0.20 & 1.14 & 3.66 \\
\hline $1 \mathrm{H}-3,132-137$ & 4.32 & 1.62 & 0.90 & 7.51 & 0.72 & 0.15 & 0.40 & 5.69 \\
\hline $2 \mathrm{H}-1,132-137$ & 5.82 & 1.29 & 0.75 & 6.25 & 0.54 & 0.19 & 0.81 & 3.32 \\
\hline $2 \mathrm{H}-2,137-142$ & 7.37 & 0.50 & 0.24 & 2.03 & 0.26 & 0.12 & 0.16 & 2.61 \\
\hline $2 \mathrm{H}-6,145-150$ & 13.45 & 0.03 & 0.11 & 0.90 & ND & 0.09 & 0.06 & \\
\hline $2 \mathrm{H}-7,49-54$ & 13.99 & 2.63 & 0.64 & 5.33 & 1.99 & 0.19 & 0.65 & 12.35 \\
\hline $3 \mathrm{H}-1,145-150$ & 15.45 & 1.48 & 0.84 & 7.04 & 0.64 & 0.18 & 0.63 & 4.17 \\
\hline $3 \mathrm{H}-5,127-132$ & 21.27 & 1.54 & 0.86 & 7.19 & 0.68 & 0.21 & 1.07 & 3.85 \\
\hline $4 \mathrm{H}-3,137-142$ & 27.87 & 1.79 & 1.09 & 9.09 & 0.70 & 0.20 & 1.09 & 4.02 \\
\hline $4 \mathrm{H}-4,145-150$ & 29.45 & 1.74 & 1.09 & 9.09 & 0.65 & 0.25 & 1.01 & 2.99 \\
\hline $4 \mathrm{H}-5,145-150$ & 30.95 & 1.76 & 1.11 & 9.25 & 0.65 & 0.23 & 0.98 & 3.29 \\
\hline $4 \mathrm{H}-7,45-50$ & 32.80 & 1.74 & 2.35 & 19.54 & ND & 0.21 & 1.06 & \\
\hline $5 \mathrm{H}-1,145-150$ & 34.45 & 1.77 & 1.12 & 9.33 & 0.65 & 0.23 & 0.97 & 3.25 \\
\hline $5 \mathrm{H}-3,137-142$ & 37.37 & 1.76 & 1.09 & 9.06 & 0.67 & 0.22 & 0.77 & 3.59 \\
\hline $5 \mathrm{H}-5,145-150$ & 40.45 & 1.05 & 0.75 & 6.23 & 0.30 & 0.14 & 0.26 & 2.44 \\
\hline $6 \mathrm{H}-3,145-150$ & 46.95 & 0.28 & 0.25 & 2.10 & 0.03 & 0.10 & 0.11 & 0.30 \\
\hline 7H-5, 137-142 & 59.37 & 1.32 & 0.80 & 6.64 & 0.52 & 0.17 & 0.78 & 3.44 \\
\hline $8 \mathrm{H}-2,145-150$ & 63.55 & 1.23 & 0.79 & 6.56 & 0.44 & 0.19 & 0.54 & 2.66 \\
\hline $9 \mathrm{H}-1,132-137$ & 68.62 & 0.00 & 0.07 & 0.59 & ND & 0.09 & 0.06 & \\
\hline $11 X-1,95-100$ & 79.25 & 1.56 & 0.96 & 8.03 & 0.60 & 0.26 & 0.87 & 2.69 \\
\hline $12 X-3,137-142$ & 92.27 & 1.39 & 0.92 & 7.63 & 0.47 & 0.18 & 0.41 & 3.03 \\
\hline $14 \mathrm{X}-3,145-150$ & 111.55 & 1.71 & 1.03 & 8.59 & 0.68 & 0.24 & 0.96 & 3.28 \\
\hline $15 X-3,136-141$ & 121.06 & 1.76 & 1.21 & 10.11 & 0.55 & 0.21 & 0.97 & 3.05 \\
\hline $16 X-3,145-150$ & 130.75 & 2.42 & 1.89 & 15.77 & 0.53 & 0.23 & 0.85 & 2.68 \\
\hline $17 X-4,137-142$ & 141.07 & 2.48 & 2.02 & 16.79 & 0.46 & 0.14 & 0.87 & 3.75 \\
\hline $18 X-3,145-150$ & 150.05 & 0.99 & 0.59 & 4.91 & 0.40 & 0.13 & 0.83 & 3.71 \\
\hline $19 X-3,137-142$ & 159.57 & 1.21 & 0.74 & 6.14 & 0.47 & 0.15 & 1.04 & 3.54 \\
\hline $20 X-2,145-150$ & 167.75 & 1.70 & 0.72 & 5.99 & 0.98 & 0.15 & 0.78 & 7.54 \\
\hline $21 X-1,136-141$ & 175.76 & 1.97 & 1.16 & 9.65 & 0.81 & 0.14 & 0.93 & 6.98 \\
\hline $22 X-3,145-150$ & 188.55 & 2.65 & 1.93 & 16.04 & 0.72 & 0.16 & 0.79 & 5.11 \\
\hline $23 X-1,132-150$ & 195.12 & 2.32 & 2.24 & 18.63 & 0.08 & 0.12 & 0.41 & 0.79 \\
\hline $23 X-5,137-142$ & 201.17 & 3.88 & 2.76 & 22.96 & 1.12 & 0.14 & 0.79 & 9.20 \\
\hline $24 X-3,145-150$ & 207.85 & 2.97 & 2.47 & 20.58 & 0.50 & 0.12 & 0.69 & 4.94 \\
\hline $25 X-3,140-150$ & 217.40 & 3.14 & 2.88 & 24.00 & 0.26 & 0.11 & 0.66 & 2.73 \\
\hline $26 \mathrm{X}-3,137-142$ & 226.78 & 3.77 & 3.14 & 26.17 & 0.63 & 0.11 & 0.66 & 6.91 \\
\hline $27 X-3,140-150$ & 236.60 & 2.60 & 1.92 & 15.99 & 0.68 & 0.10 & 0.68 & 7.66 \\
\hline $28 X-3,140-150$ & 246.30 & 3.15 & 2.71 & 22.55 & 0.44 & 0.12 & 0.63 & 4.28 \\
\hline $29 X-3,132-142$ & 255.82 & 3.56 & 3.07 & 25.60 & 0.49 & 0.10 & 0.52 & 5.76 \\
\hline $30 X-3,140-150$ & 265.50 & 2.85 & 2.46 & 20.52 & 0.39 & 0.10 & 0.65 & 4.47 \\
\hline $31 X-3,140-150$ & 275.10 & 2.86 & 2.45 & 20.42 & 0.41 & 0.11 & 0.62 & 4.46 \\
\hline $32 X-3,132-142$ & 284.62 & 2.93 & 2.56 & 21.33 & 0.37 & 0.10 & 0.61 & 4.26 \\
\hline $33 X-3,140-150$ & 294.30 & 2.79 & 2.50 & 20.80 & 0.29 & 0.10 & 0.62 & 3.21 \\
\hline
\end{tabular}

Note: $\mathrm{TN}=$ total nitrogen, $\mathrm{TH}=$ total hydrogen, $\mathrm{ND}=$ not determined . 
Table T11. Headspace gas analysis, Hole U1320A.

\begin{tabular}{|c|c|c|c|c|c|}
\hline \multirow{2}{*}{$\begin{array}{l}\text { Core, section, } \\
\text { interval }(\mathrm{cm})\end{array}$} & \multirow{2}{*}{$\begin{array}{l}\text { Depth } \\
\text { (mbsf) }\end{array}$} & \multicolumn{3}{|c|}{ Headspace gas (ppmv) } & \multirow{2}{*}{$\begin{array}{l}\mathrm{C}_{1} / \mathrm{C}_{2} \\
\text { ratio }\end{array}$} \\
\hline & & Methane & Ethane & Ethylene & \\
\hline \multicolumn{6}{|l|}{ 308-U1320A- } \\
\hline $1 \mathrm{H}-2,0-5$ & 1.5 & 2.6 & 0.0 & 0.0 & \\
\hline $2 \mathrm{H}-5,0-5$ & 10.5 & 2.2 & 0.0 & 0.0 & \\
\hline $3 \mathrm{H}-6,0-5$ & 21.5 & 7,624 & 0.0 & 0.0 & \\
\hline $4 \mathrm{H}-5,0-5$ & 29.5 & 3,163 & 0.0 & 0.0 & \\
\hline $5 \mathrm{H}-6,0-5$ & 40.5 & 1,546 & 0.0 & 0.0 & \\
\hline $6 \mathrm{H}-4,0-5$ & 47.0 & 878.1 & 0.0 & 0.0 & \\
\hline 7H-6, 0-5 & 59.5 & 3,336 & 0.0 & 0.0 & \\
\hline $8 \mathrm{H}-3,0-5$ & 63.6 & 638.5 & 0.0 & 0.0 & \\
\hline $9 \mathrm{H}-2,0-5$ & 68.8 & 1,169 & 0.0 & 0.0 & \\
\hline $11 X-2,0-5$ & 79.3 & 18,333 & 0.0 & 0.0 & \\
\hline $12 X-4,0-5$ & 92.4 & 9,485 & 0.0 & 0.0 & \\
\hline $14 X-4,0-5$ & 111.6 & 21,135 & 0.0 & 0.0 & \\
\hline $15 X-5,0-5$ & 122.7 & 57,714 & 1.3 & 0.0 & 44,396 \\
\hline $16 X-5,0-5$ & 132.3 & 40,278 & 1.2 & 0.0 & 33,565 \\
\hline $17 X-5,0-5$ & 141.2 & 50,114 & 1.6 & 0.0 & 31,321 \\
\hline $18 X-5,0-5$ & 151.6 & 11,436 & 0.0 & 0.0 & \\
\hline $19 X-4,0-5$ & 159.7 & 5,994 & 0.0 & 0.0 & \\
\hline $21 X-1,0-5$ & 174.4 & 2,933 & 0.0 & 0.0 & \\
\hline $22 X-5,0-5$ & 190.1 & 1,281 & 0.0 & 0.0 & \\
\hline $23 X-5,0-5$ & 199.8 & 813.4 & 0.0 & 0.0 & \\
\hline $24 X-4,0-5$ & 207.9 & 622.4 & 0.0 & 0.0 & \\
\hline $25 X-5,0-5$ & 219.0 & 274.0 & 0.0 & 0.0 & \\
\hline $26 X-5,0-5$ & 228.4 & 8,067 & 1.9 & 0.0 & 4,246 \\
\hline $27 X-5,0-5$ & 238.2 & 5,272 & 1.1 & 0.0 & 4,792 \\
\hline $28 X-5,0-5$ & 247.9 & 6,438 & 0.0 & 0.0 & \\
\hline $29 X-5,0-5$ & 257.5 & 8,902 & 1.6 & 0.0 & 5,564 \\
\hline $30 X-4,0-5$ & 265.6 & 12,662 & 1.9 & 0.6 & 6,664 \\
\hline $31 \times-4,0-5$ & 275.2 & 15,049 & 1.9 & 0.0 & 7,921 \\
\hline $32 X-4,0-5$ & 284.8 & 9,541 & 0.0 & 0.0 & \\
\hline $33 X-4,0-5$ & 294.4 & 10,992 & 1.4 & 0.0 & 7,851 \\
\hline
\end{tabular}

Table T12. Microbiology, Hole U1320A.

\begin{tabular}{lll}
\hline \multicolumn{1}{c}{$\begin{array}{c}\text { Core, section, } \\
\text { interval }(\mathrm{cm})\end{array}$} & $\begin{array}{c}\text { Cell density } \\
(\text { cells } / \mathrm{mL})\end{array}$ & \multicolumn{1}{c}{ Comments } \\
\hline 308-U1320A- & & \\
$1 \mathrm{H}-2,2.9-3.0$ & $1.0 \times 10^{6}$ & \\
2H-2, 7.4-7.5 & $1.2 \times 10^{6}$ & \\
$3 \mathrm{H}-5,21.4-21.5$ & $6.4 \times 10^{5}$ & Failure in contamination test \\
$4 \mathrm{H}-3,27.9-28.0$ & $4.4 \times 10^{5}$ & Failure in contamination test \\
$5 \mathrm{H}-3,37.4-37.5$ & $4.0 \times 10^{5}$ & \\
$7 \mathrm{H}-5,59.4-59.5$ & $2.0 \times 10^{5}$ & \\
$8 \mathrm{H}-2,63.5-63.6$ & $8.0 \times 10^{4}$ & \\
$11 \mathrm{X}-1,79.2-79.3$ & $8.0 \times 10^{4}$ & No contamination test \\
$12 \mathrm{X}-3,92.3-92.4$ & $6.0 \times 10^{4}$ & \\
$15 \mathrm{X}-3,121.1-121.2$ & $4.0 \times 10^{4}$ & \\
$17 \mathrm{X}-4,141.1-141.2$ & $8.0 \times 10^{4}$ & \\
$19 \mathrm{X}-3,159.6-159.7$ & $4.0 \times 10^{4}$ & \\
$23 \mathrm{X}-5,201.2-201.3$ & $4.0 \times 10^{4}$ & \\
$26 \mathrm{X}-3,226.8-226.9$ & $2.0 \times 10^{4}$ & \\
$29 \mathrm{X}-3,255.9-256.0$ & $1.5 \times 10^{4}$ & \\
$32 \mathrm{X}-3,284.7-284.8$ & $1.0 \times 10^{4}$ & \\
\hline
\end{tabular}


Table T13. Check shot stack summary, Hole 1320A.

\begin{tabular}{|c|c|c|c|c|c|}
\hline $\begin{array}{l}\text { Gun azir } \\
\text { Gun offs } \\
\text { Gun dep } \\
\text { Hydroph }\end{array}$ & $\begin{array}{l}\text { muth: } 0 \\
\text { set }(\mathrm{m}): 49 \\
\text { oth from Sc } \\
\text { hone depth }\end{array}$ & $\begin{array}{l}\text { hlumberger } \\
\text { from Schlum }\end{array}$ & $\begin{array}{l}\text { zero }(\mathrm{m}) \text { : } 13.3 \\
\text { berger zero }\end{array}$ & n): 13.3 & \\
\hline $\begin{array}{l}\text { SRD fron } \\
\text { Water } \mathrm{d}\end{array}$ & $\begin{array}{l}\text { m Schlumb } \\
\text { epth (mete }\end{array}$ & $\begin{array}{l}\text { erger zero ( } m \\
\text { rs below rig }\end{array}$ & $\begin{array}{l}\text { I): } 10.4 \\
\text { loor, mbrf): } 14\end{array}$ & 80.4 & \\
\hline $\begin{array}{l}\text { Other con } \\
\text { True ver } \\
\text { Surface }\end{array}$ & $\begin{array}{l}\text { stants: } \\
\text { tical time c } \\
\text { velocity ( } m\end{array}$ & $\begin{array}{l}\text { orrection: ye } \\
\text { /s): } 1524.0\end{array}$ & & & \\
\hline $\begin{array}{c}\text { Stack } \\
\text { number }\end{array}$ & $\begin{array}{l}\text { Measured } \\
\text { depth } \\
\text { (mbrf) }\end{array}$ & $\begin{array}{l}\text { Measured } \\
\text { one-way } \\
\text { transit time } \\
\quad(\mathrm{ms})\end{array}$ & $\begin{array}{l}\text { True vertical } \\
\text { depth from } \\
\text { SRD (mbsl) }\end{array}$ & $\begin{array}{l}\text { Corrected } \\
\text { two-way } \\
\text { transit time } \\
(\mathrm{ms})\end{array}$ & $\begin{array}{l}\text { Interval } \\
\text { velocity } \\
(\mathrm{m} / \mathrm{s})\end{array}$ \\
\hline 1015 & 1565.0 & 1034.85 & 1553.7 & 2071.29 & 1650.55 \\
\hline 1014 & 1580.0 & 1043.94 & 1568.7 & 2089.47 & 1654.18 \\
\hline 1013 & 1590.0 & 1049.98 & 1578.7 & 2101.56 & 1586.31 \\
\hline 1012 & 1612.0 & 1063.84 & 1600.7 & 2129.30 & 1640.91 \\
\hline 1011 & 1625.0 & 1071.76 & 1613.7 & 2145.15 & 1634.98 \\
\hline 1010 & 1639.9 & 1080.86 & 1628.6 & 2163.37 & 1666.82 \\
\hline 1009 & 1659.9 & 1092.86 & 1648.6 & 2187.37 & 1626.82 \\
\hline 1008 & 1674.8 & 1102.01 & 1663.5 & 2205.69 & 1572.16 \\
\hline 1007 & 1690.0 & 1111.68 & 1678.7 & 2225.03 & 1793.11 \\
\hline 1006 & 1710.0 & 1122.82 & 1698.7 & 2247.33 & 1705.27 \\
\hline 1005 & 1729.9 & 1134.48 & 1718.6 & 2270.67 & 1826.97 \\
\hline 1003 & 1746.1 & 1143.35 & 1734.8 & 2288.40 & 1133.20 \\
\hline 1002 & 1748.5 & 1145.46 & 1737.2 & 2292.64 & 1942.83 \\
\hline 1001 & 1770.0 & 1156.53 & 1758.7 & 2314.78 & \\
\hline
\end{tabular}

Notes: SRD = seismic reference depth.

Table T14. Downhole tool deployment, Site U1320A.

\begin{tabular}{|c|c|c|c|c|c|c|}
\hline \multirow[b]{2}{*}{ Hole } & \multirow[b]{2}{*}{ Tool } & \multirow[b]{2}{*}{ Deployment } & \multicolumn{2}{|c|}{ Depth } & \multirow{2}{*}{$\begin{array}{c}\text { Date } \\
\text { (Jun 2005) }\end{array}$} & \multirow{2}{*}{$\begin{array}{c}\text { Time in } \\
\text { formation }(\mathrm{min})\end{array}$} \\
\hline & & & (mbsf) & $(\mathrm{mbsl})$ & & \\
\hline \multicolumn{7}{|l|}{$308-$} \\
\hline U1320A & $\mathrm{T} 2 \mathrm{P}$ & 3 & 126.3 & 1596.3 & 8 & 45 \\
\hline U1320A & DVTPP & 1 & 203.4 & 1673.4 & 9 & 40 \\
\hline U1320A & $\mathrm{T} 2 \mathrm{P}$ & 4 & 213.0 & 1683.0 & 9 & 25 \\
\hline U1320A & DVTPP & 2 & 289.9 & 1759.9 & 9 & 10 \\
\hline
\end{tabular}

Note: T2P = temperature/dual pressure probe, DVTPP = Davis-Villinger Temperature-Pressure Probe. 
Table T15. T2P Deployment 3, Hole U1320A.

\begin{tabular}{ccl}
\hline Event & $\begin{array}{c}\text { Time } \\
(\text { CDT })\end{array}$ & \\
\hline 1 & & \multicolumn{1}{c}{ Event } \\
2 & $18: 08: 00$ & T2P on rig floor \\
3 & $18: 14: 00$ & Pressure response chamber removed from T2P tip \\
4 & $18: 14: 00$ & Shroud in place over T2P tip \\
5 & $18: 15: 00$ & T2P connected to spacer \\
6 & $18: 17: 00$ & CDS connected to spacer \\
7 & $18: 22: 00$ & CDS in connected to wireline \\
8 & $18: 23: 00$ & Start lowering T2P downhole, pumps on \\
9 & $18: 30: 00$ & Stop at 511 mbsl, pumps off \\
10 & $18: 33: 00$ & Start lowering probe, pumps on \\
11 & $18: 40: 00$ & Stop at 1011 mbsl, pumps off \\
12 & $18: 43: 00$ & Start lowering probe, pumps on \\
13 & $18: 44: 00$ & Pumping at 13 spm \\
14 & $18: 50: 00$ & Stop at 1490 mbsl, pumps off \\
15 & $18: 53: 00$ & Start lowering probe, pumps on at 13 spm \\
16 & $18: 57: 00$ & Pumps off \\
17 & $19: 00: 00$ & CDS lands in BHA \\
18 & $19: 00: 00$ & Raising BHA to 2 $\mathrm{m}$ off bottom of hole \\
19 & $19: 02: 00$ & Start penetration of T2P into sediment, $2 \mathrm{~m}$ advance of BHA \\
20 & $19: 03: 00$ & End of T2P penetration \\
21 & $19: 04: 00$ & Raising BHA 3 $\mathrm{m}$ off bottom of hole \\
22 & $19: 07: 00$ & Pumping at 10 spm \\
23 & $19: 55: 00$ & Pulling T2P uphole slowly 10 $\mathrm{m}$ \\
24 & $19: 59: 00$ & 10 $\mathrm{m}$ pull completed \\
25 & $19: 59: 00$ & Start pulling T2P uphole, pumping at 10 spm \\
26 & $20: 05: 00$ & Stop at 511 mbsl, pumps off \\
27 & $20: 09: 00$ & Start pulling T2P uphole, pumps on \\
28 & $20: 13: 00$ & CDS detached from wireline \\
29 & $20: 16: 00$ & CDS detached from spacer \\
30 & $20: 18: 00$ & Spacer detached from T2P \\
31 & $20: 18: 00$ & T2P on rig floor \\
32 & $20: 18: 00$ & T2P tip in pressure response chamber \\
33 & $20: 26: 00$ & T2P in workroom \\
34 & $20: 46: 00$ & Battery removed from T2P \\
35 & $20: 46: 00$ & T2P connected to direct-current power \\
& & Data downloaded from data logger \\
\hline & &
\end{tabular}

Notes: Date $=8$ June 2005. T2P = temperature/dual pressure probe. $\mathrm{CDS}=$ colleted delivery system. $\mathrm{BHA}=$ bottom-hole assembly . 
Table T16. T2P Deployment 4, Hole 1320A.

\begin{tabular}{|c|c|c|}
\hline Event & $\begin{array}{l}\text { Time } \\
\text { (CDT) }\end{array}$ & Event \\
\hline 1 & & Data logger started at $1 \mathrm{~Hz}$ \\
\hline 2 & $6: 24: 00$ & T2P on rig floor \\
\hline 3 & $6: 29: 00$ & Pressure response chamber removed from T2P tip \\
\hline 4 & $6: 29: 00$ & Shroud in place over T2P tip \\
\hline 5 & $6: 31: 00$ & T2P in drill pipe \\
\hline 6 & $6: 32: 00$ & T2P connected to spacer \\
\hline 7 & $6: 34: 00$ & CDS connected to spacer \\
\hline 8 & $6: 37: 00$ & CDS in connected to wireline \\
\hline 9 & $6: 39: 00$ & Start lowering T2P downhole, pumps on \\
\hline 10 & $6: 44: 00$ & Stop at $511 \mathrm{mbsl}$, pumps off \\
\hline 11 & $6: 46: 00$ & Start lowering probe, pumps on \\
\hline 12 & $6: 52: 00$ & Stop at $1011 \mathrm{mbsl}$, pumps off \\
\hline 13 & $6: 54: 00$ & Start lowering probe, pumps on \\
\hline 14 & $7: 00: 00$ & Stop at $1471 \mathrm{mbsl}$, pumps off \\
\hline 15 & 7:03:00 & Drill bit positioned $0.5 \tilde{n} 0.75 \mathrm{~m}$ off bottom of hole \\
\hline 16 & 7:12:00 & CDS lands in $\mathrm{BHA}$, probe in formation \\
\hline 17 & 7:12:00 & Raising BHA $2.5 \mathrm{~m}$ \\
\hline 18 & 7:17:00 & Pumping at $10 \mathrm{spm}$ \\
\hline 19 & $7: 36: 00$ & Pulling T2P uphole to disengage CDS \\
\hline 20 & $7: 37: 00$ & Pulling T2P uphole \\
\hline 21 & $7: 51: 00$ & T2P tip at $372 \mathrm{mbsl}$ \\
\hline 22 & $7: 54: 00$ & T2P lowered to $511 \mathrm{mbsl}$, pumps off \\
\hline 23 & $7: 56: 00$ & Pulling T2P uphole \\
\hline 24 & $8: 05: 00$ & CDS lowered to retracted position \\
\hline 25 & $8: 08: 00$ & CDS detached from spacer \\
\hline 26 & $8: 09: 00$ & T2P detached from spacer \\
\hline 27 & $8: 09: 00$ & $\mathrm{~T} 2 \mathrm{P}$ tip in pressure response chamber \\
\hline 28 & $8: 16: 00$ & $\mathrm{~T} 2 \mathrm{P}$ in workroom \\
\hline 29 & & Battery removed from $\mathrm{T} 2 \mathrm{P}$ \\
\hline 30 & & $\mathrm{~T} 2 \mathrm{P}$ connected to direct-current power \\
\hline 31 & & Data downloaded from data logger \\
\hline
\end{tabular}

Notes: Date $=9$ June 2005. T2P $=$ temperature/dual pressure probe. $\mathrm{CDS}=$ colleted delivery system. $\mathrm{BHA}=$ bottom-hole assembly. 